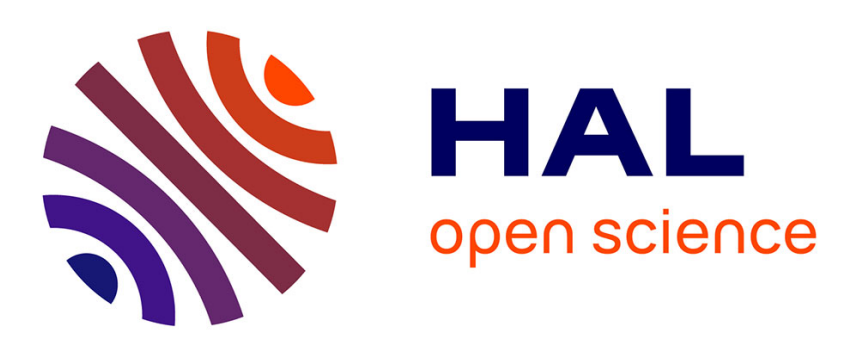

\title{
Chemistry of the Androconial Secretion of the Ithomiine Butterfly Oleria onega
}

\author{
Patrick Stamm, Florian Mann, Melanie Mcclure, Marianne Elias, Stefan \\ Schulz
}

\section{- To cite this version:}

Patrick Stamm, Florian Mann, Melanie Mcclure, Marianne Elias, Stefan Schulz. Chemistry of the Androconial Secretion of the Ithomiine Butterfly Oleria onega. Journal of Chemical Ecology, 2019, 45 (9), pp.768-778. 10.1007/s10886-019-01100-5 . hal-02400766

\section{HAL Id: hal-02400766 https://hal.science/hal-02400766}

Submitted on 5 Jun 2020

HAL is a multi-disciplinary open access archive for the deposit and dissemination of scientific research documents, whether they are published or not. The documents may come from teaching and research institutions in France or abroad, or from public or private research centers.
L'archive ouverte pluridisciplinaire HAL, est destinée au dépôt et à la diffusion de documents scientifiques de niveau recherche, publiés ou non, émanant des établissements d'enseignement et de recherche français ou étrangers, des laboratoires publics ou privés. 
Manuscript published in Journal of Chemical Ecology as:

Stamm P, Mann F, McClure M, Elias M, Schulz S. 2019. Chemistry of the Androconial Secretion of the Ithomiine Butterfly Oleria onega. Journal of Chemical Ecology, 45(9), 768-778. doi: 10.1007/ s10886-019-01100-5

\section{CHEMISTRY OF THE ANDROCONIAL SECRETION OF THE ITHOMIINE BUTTERFLY}

\section{Oleria onega}

Patrick Stamm, ${ }^{1 \ddagger}$ Florian Mann, ${ }^{1 \ddagger}$ Melanie McClure, ${ }^{2}$ Marianne Elias, ${ }^{2}$ Stefan Schulz ${ }^{1, *}$

${ }^{1}$ Institute of Organic Chemistry, Technische Universität Braunschweig, Hagenring 30, 38106 Braunschweig, Germany

${ }^{2}$ Institut de Systématique Evolution Biodiversité, Centre National de la Recherche Scientifique, MNHN, Sorbonne Université, EPHE, Université des Antilles, 45 rue Buffon, CP 50, 75005 Paris, France

*Corresponding author: Email stefan.schulz@tu-bs.de, phone +49 5313917353

$\ddagger$ These authors contributed equally.

ORCID: S. Schulz 0000-0002-4810-324X, P. Stamm: 0000-0002-1716-8171, M. Elias: 00000002-1250-2353 
Abstract- Ithomiine butterflies use pyrrolizidine alkaloids (PAs) as precursors for male pheromones, such as dihydropyrrolizines or lactones. In contrast to most other ithomiine genera, none of these compounds have ever been detected in Oleria species. The absence of these compounds is thought to be the result of limited access to PA-containing plants. Here we investigate the contents of the androconia of Oleria onega caught in the wild when PA containing plants were abundant. Although the PA lycopsamine was detected in the hairpencils, none of the other known PA-derived compounds were present. Instead, the unsubstituted core of the PA necine base, 1 -methylene- $1 H$-pyrrolizine (13), a very unstable compound, was found. The identity of this compound was proven by synthesis. Although its formation in nature appears very likely, $\mathbf{1 3}$ is also formed during GC analysis of PAs, making its natural formation ambiguous. Nevertheless, its reactivity makes it a good candidate for a signaling compound, because its rapid degradation can be used for transporting spatial and time information. In addition, several other compounds, likely used in intraspecific communication, were identified. All these compounds are reported for the first time as natural products or from insects. These include 9-hydroxynonanoic acid (21) and (Z)9-hydroxy-6-enoic acid (18), as well as their condensation products with 11-hexadecenoic- and octadecenoic acids. Furthermore, self-condensation products, such as (Z)-9-[(9-hydroxynon-6enoyl)oxy]- and 9-[(9-hydroxynonanoyl)oxy]nonanoic acid and non-6-enoic acids $(\mathbf{3 5}, \mathbf{3 6}, \mathbf{3 8}, \mathbf{4 0})$ were identified, together with the known compounds 2-heptadecanol (39) and 6,10,14trimethylpentadecan-2-ol (37). In summary, O. onega appears to lack enzymes to produce dihydropyrrolizines. In stark contrast to other ithomiine genera, a unique blend of oxidized fatty acids seems to be used instead. 
Key Words- Pheromones, alkaloids, male butterflies, Hyposcada, oxidized fatty acids, ester acids.

\section{INTRODUCTION}

Ithomiines (Nymphalidae: Ithomiini), also known as clearwing butterflies, are Neotropical butterflies that form a species-rich group of more than 390 species in approximately 50 genera (Chazot et al. 2019). Adult males are attracted to pyrrolizidine alkaloid (PA, e. g. 1) containing plants from which they sequester these compounds (Boppré 1986). PAs are effective in deterring predators and are transferred to females in the seminal fluid during copulation, similar to the related danaine butterflies or PA sequestering arctiine moths (Eisner and Meinwald 1995). Male ithomiines also use PAs as precursors for pheromones, which are disseminated by specialized scales present on the male wings, called androconia (Edgar et al. 1976; Schulz et al. 2004). In ithomiines, the androconia consist of erectable brushes which can be exposed by the males when in proximity to a female so as to diffuse a pheromone blend that is perceived by the female antennae (Figure 1). 


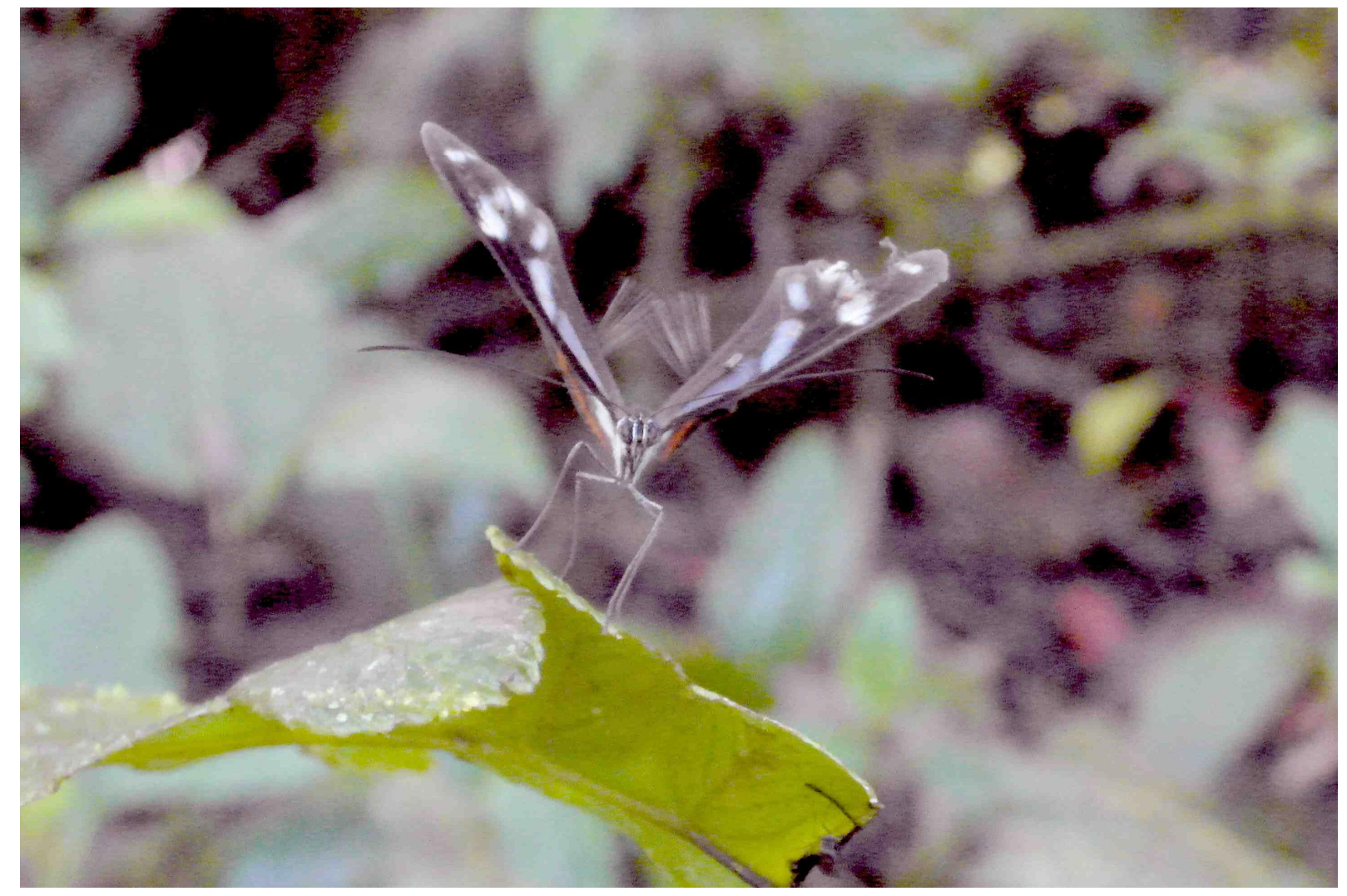

Fig. 1 Male Oleria onega janarilla with erected scent brushes (androconia). Photo: S. Gallusser

A multitude of PA-derived compounds have previously been identified in these androconia (Figure 2). These include dihydropyrrolizines such as hydroxydanaidal (2), danaidal (3), hydroxydanaidoic acid (4), and methyl hydroxydanaidoate (5), all group 1 compounds (derived from the necine base of PAs) according to Schulz et al. (2004). In addition, also lactones such as $\beta$-viridiflorin lactone (6), a group 2 compound (unmodified necic acid lactone), or ithomiolide A (7), a group 3 compound that constitute oxidatively modified necic acid lactones, were identified (Schulz 1992; Schulz et al. 1988; Schulz et al. 2004; Edgar et al. 1976). Biosynthetic studies in the arctiine moth Creatonotos transiens, which uses $\mathbf{2}$ as a male pheromone, have revealed that these compounds are biosynthesized from PAs taken up during the larval stage (Schulz et al. 1993). Alkaloids like lycopsamine (1) with (7R)-stereochemistry can serve as precursors, but other plant 
derived $(7 S)$-alkaloids such as heliotrine can be epimerized to required $(7 R)$-alkaloids, as has been shown in the ithomiine Mechanitis polymnia (Trigo et al. 1994). Whereas dihydropyrrolizines such as $\mathbf{2}$ and $\mathbf{5}$ and the lactone $\mathbf{6}$ have also been found to occur in other Lepidoptera such as the danaines and arctiines (Schulz 1998; Honda et al. 2006), ithomiolide 7 is specific to ithomiines.

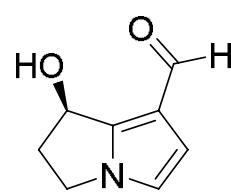

2

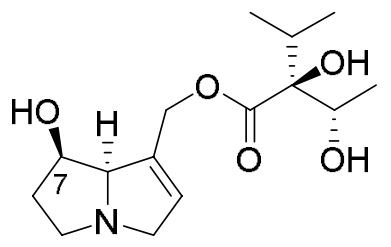

1<smiles>O=C(O)c1ccn2c1C(O)CC2</smiles>

4

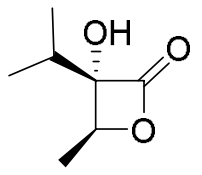

6<smiles>O=Cc1ccn2c1CCC2</smiles>

3<smiles>CCOC(=O)c1ccn2c1C(O)CC2</smiles>

5

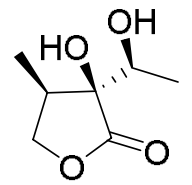

7

Fig. 2 The PA lycopsamine (1) and PA-derived semiochemicals of ithomiine butterflies belonging to group 1 (2-5), group $2(\mathbf{6})$, and group 3 (7)

We have previously reported a comparative analysis of the chemistry of androconia of 54 species present in 30 ithomiine genera (Schulz et al. 2004). Most species contained at least one of the compounds discussed, although large variations were found between individuals. In fact, some individuals contained no PA-derived compounds, despite their presence in other individuals of the same species. This absence may be due to a lack of access to PA-containing plants by these individuals. Furthermore, some species did not contain any of these compounds, despite 
congeneric species possessing dihydropyrrolizines and/or lactones. In addition, the use of compounds other than PA-derivatives as pheromones cannot be excluded. In summary, while 26 ithomiine genera contained PA-derived compounds, four genera did not. Two of them, Oleria and Hyposcada, which belong to the subtribe Oleriina, are closely related. These genera were extensively sampled in the past and have never shown any compound of groups 1-3 in the androconia. However, compounds not related to PAs were observed in the androconia of these species and many other ithomiines. As such, further investigations into the chemistry of the androconia of the Oleriina, and specifically the species Oleria onega Hewitson, (Nymphalidae: Ithomiini), were undertaken from specimens collected in north-eastern Peru. The lowland subspecies O. onega janarilla was used, and compared to the subspecies Oleria onega ssp. nov. 3, which occurs at higher altitudes. We report here on the chemical composition of their androconia and the identification of an instable pyrrolizine as well as a suite of novel acids and esters that are likely involved in intraspecific communication in Oleria.

\section{METHODS AND MATERIAL}

General Experimental Procedures. UV/Vis spectra were obtained using a Varian Carry 100 Bio spectrometer. IR spectra were recorded on a Bruker Tensor 27 (diamond ATR, all compounds except 13) and a Dani DiscovIR-GC coupled to an Agilent 7890B gas chromatograph (compound 13). NMR analyses were performed on Bruker Avance III HD 300N, DRX 400, III-400 and II-600 spectrometers at room temperature. Chemical shifts are reported in ppm from tetramethylsilane as an internal standard. Mass spectra were recorded in electron ionization mode $(70 \mathrm{eV})$ by GC/MS analysis using Agilent HP 6890/MSD 5973 and Agilent HP 7890A/MSD 5975 GC/MS systems. The gas chromatographs were equipped with Agilent HP5-MS fused-silica capillary columns (30 
$\mathrm{m} \times 0.25 \mathrm{~mm}$ i.d. $\times 0.25 \mu \mathrm{m})$ using helium as the carrier gas. GC analyzing the stability of $\mathbf{1 3}$ was performed on an Agilent 7890A gas chromatograph, equipped with an Agilent HP5 fused-silica capillary column $(30 \mathrm{~m} \times 0.25 \mathrm{~mm}$ i.d. $\times 0.25 \mu \mathrm{m})$ using hydrogen as the carrier gas. The injector temperature was set to $170^{\circ} \mathrm{C}$ to avoid thermal depolymerization of degradation products of $\mathbf{1 3}$ contained in the samples. A short temperature program was used starting at $70^{\circ} \mathrm{C}$. After one minute, the temperature was raised with $60^{\circ} \mathrm{C} / \mathrm{min}$ to $320^{\circ} \mathrm{C}$. TLC was performed on MachereyNagel polygram-SIL-G/UV254 plates. The spots were detected with UV light (254 nm), potassium permanganate, vanillin and phosphomolybdic acid staining solutions, Vaughn's reagent, or Ehrlich's reagent (pyrrole derivatives, $1 \mathrm{~g}$ p-(dimethylamino)benzaldehyde in $50 \mathrm{~mL} 20 \%$ aqueous $\mathrm{HCl}$ ). Column chromatography was performed on silica gel 60 (Fluka, particle size 0.040$0.063 \mathrm{~mm}$, mesh $230-440$ ASTM) which was neutralized by addition of some triethylamine during setup when indicated, or on neutral alumina (ICN Alumina N). Reactions sensitive to air or water were carried out in heat-dried glassware under a nitrogen atmosphere. Solvents were dried by conventional methods. Unless stated otherwise, commercial chemicals were used without further purification.

Biological Material. Butterflies were collected in December 2015 in north-eastern Peru (San Martín department) during the rainy season (November to April). Oleria onega janarilla was collected in lowland forest habitat on Pongo-Barranquita road (6 $6^{\circ} 7^{\prime} 53^{\prime \prime}$ 'S 76 $14^{\prime} 38^{\prime \prime} \mathrm{W}$ alt $\left.200 \mathrm{~m}\right)$, while Oleria onega ssp. nov. 3 was collected in high altitudinal forest habitat on Moyobamba -

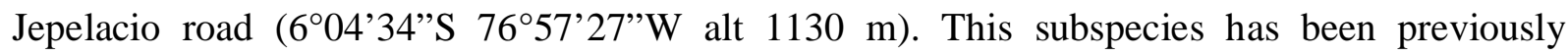
characterized as O. onega ssp. nov. (De-Silva et al. 2011) or as Oleria onega ssp. nov. 3 (Dasmahapatra et al. 2010). For further details see Figure S1 (SI). The hairpencils (i.e. androconial 
scales) of 10 males were dissected and extracted together in $200 \mu \mathrm{L}$ ultrapure dichloromethane shortly after capture. Samples were kept at $-20{ }^{\circ} \mathrm{C}$ until analysis.

Synthesis. Ethyl 2-oxo-2-(1H-pyrrol-2-yl)acetate (10). Pyridine (3.75 mL, $46.5 \mathrm{mmol}$, 2.1 equiv) was added to a solution of ethyl 2-chloro-2-oxoacetate $(\mathbf{9}, 2.94 \mathrm{~mL}, 26.4 \mathrm{mmol}$, 1.2 equiv) in dry $\mathrm{CH}_{2} \mathrm{Cl}_{2}(20 \mathrm{~mL})$ at $-80{ }^{\circ} \mathrm{C}$ (Brandänge and Lundin 1971; Fashe et al. 2014). The resulting viscous solution was diluted with $\mathrm{CH}_{2} \mathrm{Cl}_{2}(5 \mathrm{~mL})$ and pyrrole $(\mathbf{8}, 1.56 \mathrm{~mL}, 22.5 \mathrm{mmol}$, 1 equiv) in $\mathrm{CH}_{2} \mathrm{Cl}_{2}(10 \mathrm{~mL})$ was added dropwise over $1 \mathrm{~h}$. After stirring for $3 \mathrm{~h}$ at $-80{ }^{\circ} \mathrm{C}$, the reaction mixture was washed with diluted $\mathrm{HCl}$. The aqueous layer was extracted with $\mathrm{CH}_{2} \mathrm{Cl}_{2}$ and the combined organic layers were washed with sat. aq. $\mathrm{NaHCO}_{3}$, dried with $\mathrm{MgSO}_{4}$, filtered and concentrated in vacuo. The residue was purified by column chromatography on neutralized silica (pentane/diethyl ether 2:1) to yield ethyl 2-oxo-2-(1H-pyrrol-2-yl)acetate (10): beige solid (3.48 g, $20.8 \mathrm{mmol}, 93 \%$ ); $R_{f}=0.27$ (pentane/diethyl ether 2:1); IR (neat) $v_{\max } 3319,3128,2979,2938$, $2907,2872,1728,1689,1634,1535,1477,1405,1382,1367,1322,1262,1235,1098,1047,1021$, 917, 869, 808, 751, 692, 646, $602 \mathrm{~cm}^{-1} ;{ }^{1} \mathrm{H}$ NMR $\left(\mathrm{CDCl}_{3}, 300 \mathrm{MHz}\right) \delta 10.27(1 \mathrm{H}, \mathrm{br} \mathrm{s}, \mathrm{NH}), 7.40$ $\left(1 \mathrm{H}, \mathrm{dd}, J=4.0,1.3 \mathrm{~Hz}, \mathrm{CH}_{\mathrm{Ar}}\right), 7.21\left(1 \mathrm{H}, \mathrm{dd}, J=2.3,1.3 \mathrm{~Hz}, \mathrm{CH}_{\mathrm{Ar}}\right), 6.36(1 \mathrm{H}, \mathrm{dd}, J=4.0,2.4 \mathrm{~Hz}$, $\left.\mathrm{CH}_{\mathrm{Ar}}\right), 4.41\left(2 \mathrm{H}, \mathrm{q}, J=7.1 \mathrm{~Hz}, \mathrm{CH}_{2}\right), 1.41\left(3 \mathrm{H}, \mathrm{t}, J=7.2 \mathrm{~Hz}, \mathrm{CH}_{3}\right) ;{ }^{13} \mathrm{C} \mathrm{NMR}\left(75 \mathrm{MHz}, \mathrm{CDCl}_{3}\right) \delta$ $162.2(\mathrm{C}), 129.4(\mathrm{C}), 128.2(\mathrm{CH}), 122.4(\mathrm{CH}), 112.1(\mathrm{CH}), 62.3\left(\mathrm{CH}_{2}\right), 14.0\left(\mathrm{CH}_{3}\right)$, second carbonyl signal not observed; EIMS m/z 167 (34, [M]+), 123 (5), 95 (14), 94 (100), 67 (4), 66 (43), 65 (5), 64 (3), 40 (7), 39 (26), 38 (8), 37 (3).

Ethyl 3H-pyrrolizine-7-carboxylate (11). Ester $\mathbf{1 0}$ (1.72 g, $10.3 \mathrm{mmol}, 1$ equiv) was added to a suspension of sodium hydride (60\% dispersion in mineral oil, $0.432 \mathrm{~g}, 10.8 \mathrm{mmol}, 1.05$ equiv) in dry diethyl ether (50 mL) (Brandänge and Lundin 1971; Fashe et al. 2014). After stirring for $1 \mathrm{~h}$ at $\mathrm{rt}$, triphenylvinylphosphonium bromide $(3.88 \mathrm{~g}, 10.5 \mathrm{mmol}, 1.02$ equiv) was added and the 
turbid reaction mixture was heated to reflux for $21 \mathrm{~h}$. Subsequently, the mixture was cooled to room temperature, filtered and the residue was extensively washed with diethyl ether. The filtrate was concentrated in vacuo and purified by column chromatography on neutralized silica (pentane $\rightarrow$ pentane/diethyl ether 2:1) to yield ethyl 3H-pyrrolizine-7-carboxylate (11): yellowish oil $(0.41 \mathrm{~g}, 2.31 \mathrm{mmol}, 22 \%) ; R_{f}=0.28$ (pentane/diethyl ether 2:1); IR (neat) $v_{\max } 3108,2979,2904$, 1686, 1580, 1535, 1480, 1429, 1369, 1338, 1296, 1243, 1171, 1131, 1092, 1048, 1020, 960, 936, 873, 828, 782, 704, 653, $531 \mathrm{~cm}^{-1} ;{ }^{1} \mathrm{H} \mathrm{NMR}\left(\mathrm{CDCl}_{3}, 300 \mathrm{MHz}\right) \delta 6.91(1 \mathrm{H}, \mathrm{dtd}, J=6.0,2.2$, $0.6 \mathrm{~Hz},=\mathrm{CH}), 6.84\left(1 \mathrm{H}, \mathrm{dq}, J=2.9,0.8 \mathrm{~Hz}, \mathrm{CH}_{\mathrm{Ar}}\right), 6.64\left(1 \mathrm{H}, \mathrm{dd}, J=2.9,1.0 \mathrm{~Hz}, \mathrm{CH}_{\mathrm{Ar}}\right), 6.44(1 \mathrm{H}$, $\mathrm{dtd}, J=6.0,2.0,1.0 \mathrm{~Hz},=\mathrm{CH}), 4.42\left(2 \mathrm{H}, \mathrm{td}, J=2.1,0.9 \mathrm{~Hz}, \mathrm{CH}_{2}\right), 4.28\left(2 \mathrm{H}, \mathrm{q}, J=7.1 \mathrm{~Hz}, \mathrm{CH}_{2}\right)$, $1.34\left(3 \mathrm{H}, \mathrm{t}, J=7.1 \mathrm{~Hz}, \mathrm{CH}_{3}\right) ;{ }^{13} \mathrm{C} \mathrm{NMR}\left(75 \mathrm{MHz}, \mathrm{CDCl}_{3}\right) \delta 164.6(\mathrm{C}), 145.7(\mathrm{C}), 131.5(\mathrm{CH})$, $123.9(\mathrm{CH}), 117.2(\mathrm{CH}), 112.9(\mathrm{CH}), 104.7(\mathrm{C}), 59.3\left(\mathrm{CH}_{2}\right), 52.5\left(\mathrm{CH}_{2}\right), 14.4\left(\mathrm{CH}_{3}\right)$; EIMS m/z $177\left(67,[\mathrm{M}]^{+}\right), 149(15), 148(23), 133(8), 132$ (72), 131 (7), 120 (6), $118(5), 105(23), 104$ (100), 103 (10), 78 (12), 77 (18), 76 (9), 75 (4), 74 (3), 66 (3), 63 (2), 52 (5), 51 (19), 50 (8), 39 (3).

(3H-Pyrrolizin-7-yl)methanol (12). A solution of 11 (0.54 g, 3.05 mmol, 1 equiv) in dry diethyl ether $(10 \mathrm{~mL})$ was slowly added at $0^{\circ} \mathrm{C}$ to a suspension of $\mathrm{LiAlH}_{4}(0.41 \mathrm{~g}, 10.7 \mathrm{mmol}, 3.5$ equiv $)$ in dry diethyl ether $(10 \mathrm{~mL})$ (Fashe et al. 2014). The brownish reaction mixture was stirred for $15 \mathrm{~min}$ at $0^{\circ} \mathrm{C}$ and for $30 \mathrm{~min}$ at room temperature. Then the mixture was diluted with diethyl ether (30 mL), cooled to $0^{\circ} \mathrm{C}$ and $\mathrm{H}_{2} \mathrm{O}(0.4 \mathrm{~mL}), 15 \%$ aqueous $\mathrm{NaOH}(0.4 \mathrm{~mL})$ and an additional $1.2 \mathrm{~mL}$ $\mathrm{H}_{2} \mathrm{O}$ was added dropwise. After warming to room temperature, $\mathrm{MgSO}_{4}$ was added and the resulting mixture was stirred for $5 \mathrm{~min}$, filtered and concentrated in vacuo, giving crude (3H-pyrrolizin-7yl)methanol (12) as an orange solid (0.38 g, $2.83 \mathrm{mmol}, 93 \%)$ which was used in the next step without further purification. $R_{f}=0.26$ (pentane/diethyl ether $\left.1: 1\right) ;{ }^{1} \mathrm{H} \mathrm{NMR}\left(\mathrm{CDCl}_{3}, 300 \mathrm{MHz}\right) \delta$ $6.89(1 \mathrm{H}, \mathrm{br} \mathrm{d}, J=2.7 \mathrm{~Hz}, \mathrm{CHAr}), 6.67(1 \mathrm{H}, \mathrm{dtd}, J=6.1,2.3,0.6 \mathrm{~Hz},=\mathrm{CH}), 6.25(1 \mathrm{H}, \mathrm{br} \mathrm{d}, J=$ 
$\left.2.7 \mathrm{~Hz}, \mathrm{CH}_{\mathrm{Ar}}\right), 6.20(1 \mathrm{H}, \mathrm{dtd}, J=6.0,2.1,1.0 \mathrm{~Hz},=\mathrm{CH}), 4.60\left(2 \mathrm{H}, \mathrm{br} \mathrm{s}, \mathrm{CH}_{2}\right), 4.44-4.41(2 \mathrm{H}, \mathrm{m}$, $\left.\mathrm{CH}_{2}\right), 1.68(1 \mathrm{H}$, br s, OH)$){ }^{13} \mathrm{C}$ NMR $\left(75 \mathrm{MHz}, \mathrm{CDCl}_{3}\right) \delta 139.5(\mathrm{C}), 127.4(\mathrm{CH}), 122.4(\mathrm{CH}), 116.9$ $(\mathrm{CH}), 112.3(\mathrm{C}), 111.7(\mathrm{CH}), 58.1\left(\mathrm{CH}_{2}\right), 51.9\left(\mathrm{CH}_{2}\right)$.

1-Methylene-1H-pyrrolizine (13). A solution of crude 12 (23.6 mg, $0.175 \mathrm{mmol}, 1$ equiv) in dry $\mathrm{CH}_{2} \mathrm{Cl}_{2}$ (3 mL) was treated with 1,5-diazabicyclo[4.3.0]non-5-ene (DBN, $0.07 \mathrm{~mL}, 0.53 \mathrm{mmol}$, 3 equiv) and trifluoroacetic anhydride $\left(32 \mu 1,0.23 \mathrm{mmol}, 1.3\right.$ equiv, distilled over $\left.\mathrm{P}_{4} \mathrm{O}_{10}\right)$ at -30 ${ }^{\circ} \mathrm{C}$. After stirring for $5 \mathrm{~min}$, the red reaction mixture was directly subjected to column chromatography on neutral alumina (activity II, pentane). The combined product fractions were concentrated in vacuo at $-40{ }^{\circ} \mathrm{C}$ to $-50{ }^{\circ} \mathrm{C}$. The yellowish residue was rapidly dissolved in acetonitrile- $d_{3}(0.6 \mathrm{~mL})$ and analyzed by NMR spectroscopy. The yield of 1-methylene- $1 H$ pyrrolizine $(\mathbf{1 3}, 3.1 \mathrm{mg}, 0.026 \mathrm{mmol}, 15 \%)$ was estimated on the basis of the residual proton signal of the solvent. $R_{f}=0.27$ (pentane); IR (neat) $v_{\max } 3137,3116,3102,1622,1534,1519,1457,1395$, 1370, 1315, 1269, 1254, 1107, 1079, 1055, 1005, 890, 757, 736, $707 \mathrm{~cm}^{-1} ;{ }^{1} \mathrm{H}$ NMR $\left(\mathrm{CD}_{3} \mathrm{CN}\right.$, $300 \mathrm{MHz}) \delta 7.08(1 \mathrm{H}, \mathrm{dm}, J=4.0 \mathrm{~Hz},=\mathrm{CH}), 6.80\left(1 \mathrm{H}, \mathrm{dm}, J=2.7 \mathrm{~Hz}, \mathrm{CH}_{\mathrm{Ar}}\right), 6.35(1 \mathrm{H}, \mathrm{br} \mathrm{d}, J=$ $\left.3.5 \mathrm{~Hz}, \mathrm{CH}_{\mathrm{Ar}}\right), 6.15\left(1 \mathrm{H}, \mathrm{ddd}, J=3.5,2.7,1.1 \mathrm{~Hz}, \mathrm{CH}_{\mathrm{Ar}}\right), 5.98(1 \mathrm{H}, \mathrm{br} \mathrm{d}, J=4.0 \mathrm{~Hz},=\mathrm{CH}), 5.59$ (1H, br s, CHH), 5.33 (1H, br s, CHH); EIMS m/z 118 (9), $117\left(100,[\mathrm{M}]^{+}\right), 116(13), 115(1), 114$ (1), 91 (6), 90 (48), 89 (45), 88 (1), 87 (1), 86 (1), 85 (1), 78 (3), 77 (1), 76 (1), 75 (1), 74 (1), 67 (1), 66 (1), 65 (2), 64 (7), 63 (14), 62 (6), 61 (2), 58.5 (4), 52 (3), 51 (6), 50 (4), 41 (1), 40 (1), 39 (5), 38 (3), 37 (1); gas chromatographic retention index (HP5-MS) $I=1079$.

The synthetic procedures of all other compounds can be found in the supplementary material (SM). 


\section{RESULTS}

In exploratory experiments, extracts of the androconia from individuals of Oleria onega, $O$. gunilla, Hyposcada anchiala, and H. illinissa margarita were analyzed by GC/MS. While none of the Oleria individuals contained any PAs or derivatives, the two Hyposcada species showed small amounts of $\mathbf{2}$, the respective acid (4), and the norhydroxy-compound danaidal (3). A potential reason for the lack of such volatile compounds in Oleria might be a limited access to PAcontaining plants (Schulz et al. 2004).

GC/MS analyses of androconia. To test this hypothesis, $O$. onega was collected in the field in Peru during the rainy season. At this time of the year, PA-containing Heliotropium plants, often visited by ithomiines, are very abundant. Therefore, access to PA-containing plants by $O$. onega seemed likely. The androconia of ten individuals were pooled and analyzed by GC/MS (Figure 3a). Mass spectra indicated the presence of various common saturated $\mathrm{C}_{16^{-}}$and $\mathrm{C}_{18}$-acids, often present in butterfly androconia, but also shorter acids $(\mathbf{B}, \mathbf{C})$ eluting earlier as well as a couple of unknown fatty acid derivatives and other aliphatic compounds (D-G). 

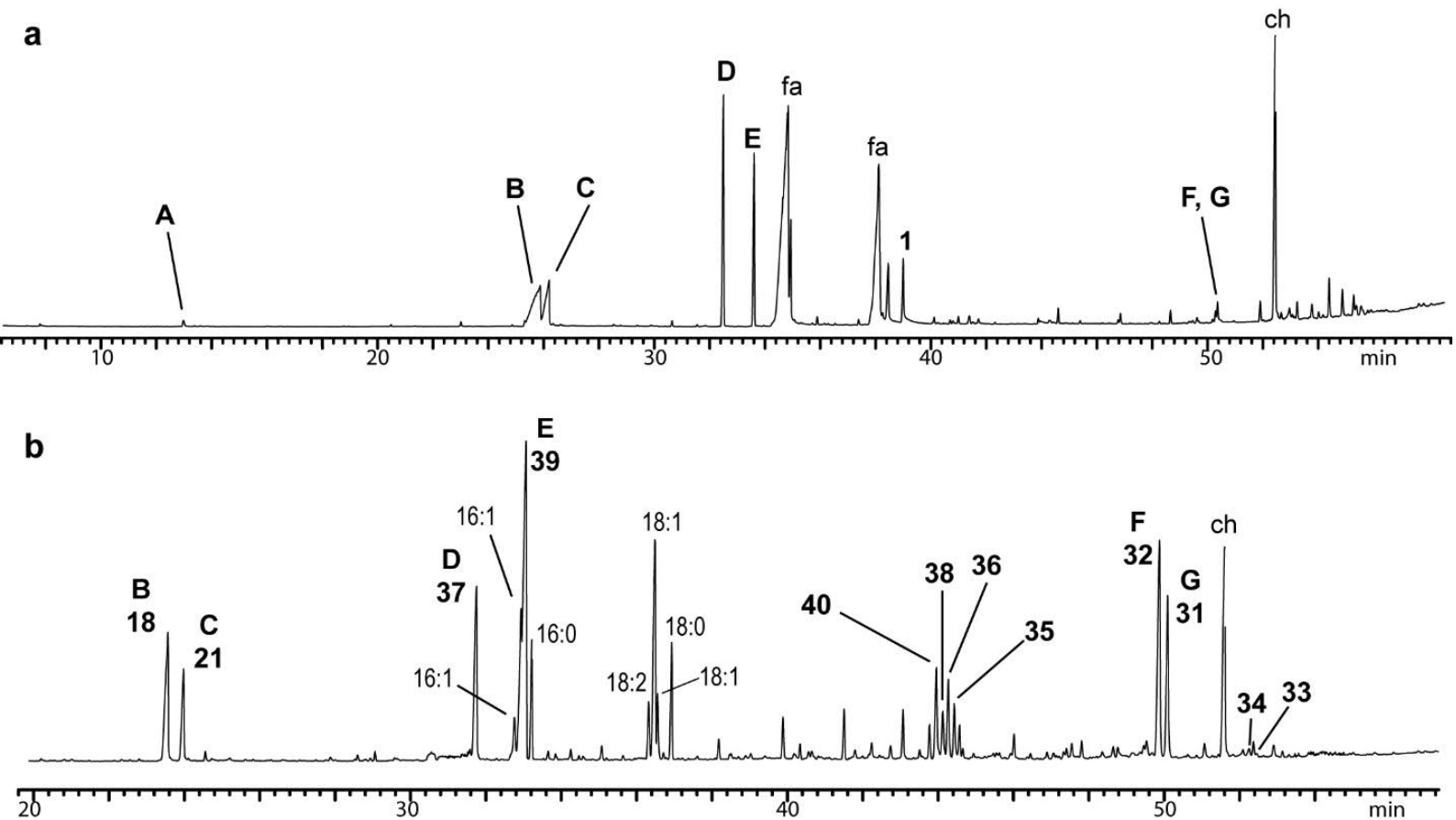

Fig. 3 TIC of extracts of androconia of Oleria onega janarilla. a) total extract containing free fatty acids. Compounds identified in this work are labelled A-G. fa: mixtures of $\mathrm{C}_{16^{-}}$and $\mathrm{C}_{18}$-fatty acids; ch: cholesterol. b) Extract after methylation with diazomethane. The PA derivatives A and $\mathbf{1}$ cannot be detected anymore. Compound numbers refer to the parent acids for convenience, although the peaks actually represent their methyl esters. Fatty acids are annotated according to their chain length and degree of unsaturation, e. g. 16:1 denotes hexadecenoic acid. Non assigned peaks are either impurities or trace components. The structures of the compounds can be found in Figure 9.

In addition, the extract contained the PA lycopsamine (1), indicating that the butterflies indeed took up PAs as other ithomiines. Nevertheless, none of the compounds 2-7 were detected. Instead, a minor compound A showed a mass spectrum (Figure S5, SM) almost identical to those of indole (gas chromatographic retention index after van den Dool and Kratz (1963) I 1288), benzyl cyanide (I 1161), or indolizine (1245), but the shorter retention index of $I 1076$ excluded these structures. 
We therefore assumed that $\mathbf{A}$ might be 1-methylene-1H-pyrrolizine (13), the highly reduced core structure of the necine base part of PAs (Figure 4).

Identification and synthesis of 1-methylene-1H-pyrrolizine (13). This likely structure of $\mathbf{A}$, an aza-fulvene, was proven by synthesis. The synthesis turned out to be difficult, due to the inherent instability known for unsubstituted fulvenes (Neuenschwander 2015). Initial experiments to obtain 13 by oxidation and elimination of the PA monocrotaline or the necic base retronecine failed. Other attempts also proved unsuccessful, resulting either in the absence of the product or low yields in a difficult to separate mixture. 2,3-Dihydro- $1 H$-pyrrolizin-1-one can be readily prepared from pyrrole and methyl acrylate (Jefford et al. 1994; Kim et al. 2016). Dehydrogenation via a selenoxide resulted in a good yield of $1 \mathrm{H}$-pyrrolizin-1-one, however, introduction of the methylene group via Wittig-, Petasis- or methyl lithium addition approaches did not result in a clean product. Finally, the synthesis outlined in Figure 4 was successful. Pyrrole (8) was acylated with acid chloride 9 followed by a reaction with vinyltriphenylphosphonium bromide to obtain ethyl $3 \mathrm{H}$ pyrrolizine-7-carboxylate (11) (Brandänge and Lundin 1971; Fashe et al. 2014). Reduction with $\mathrm{LiAlH}_{4}$ according to Fashe et al. (2014) yielded the alcohol 12. The authors reported that 12 slowly rearranges to its tautomer 14 (Fashe et al. 2014). This tautomerization also occurred during purification on silica, leading to a 3:1 mixture of $\mathbf{1 2}$ and $\mathbf{1 4}$. Consequently, the final step in the synthesis, a dehydration leading to the aza-fulvene, was performed with the crude product. Best elimination results were obtained with trifluoroacetic anhydride in the presence of a base such as pyridine. At $-30{ }^{\circ} \mathrm{C}$, instantaneous elimination occurs, resulting in $\mathbf{1 3}$ that was then purified by flash chromatography on alumina. Aza-fulvene $\mathbf{1 3}$ proved to be very unstable, degrading quickly in solution at room temperature, but ${ }^{1} \mathrm{H}$ NMR, IR and mass spectra were successfully obtained. 
The mass spectra and the retention index I of compound $\mathbf{A}$ and synthetic $\mathbf{1 3}$ were identical, thus confirming their identity.<smiles>c1cc[nH]c1</smiles>

8<smiles>CCOC(=O)C(=O)Cl</smiles>

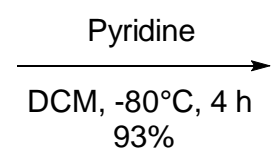

$93 \%$<smiles>CCOC(=O)C(=O)c1ccc[nH]1</smiles>

10

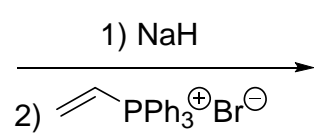

$\mathrm{Et}_{2} \mathrm{O}, 21 \mathrm{~h}$

$22 \%$<smiles></smiles>

11

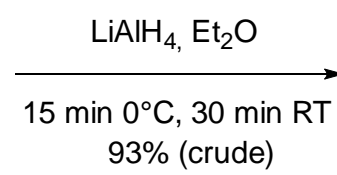

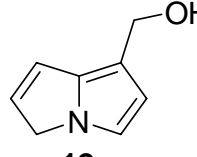

12

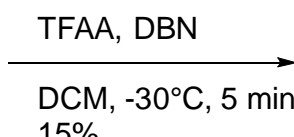

$15 \%$

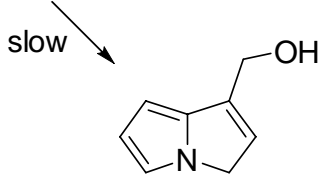

14

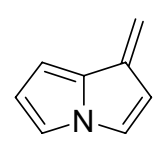

13

Fig. 4 Synthesis of 1-methylene-1H-pyrrolizine (13)

Solutions of $\mathbf{1 3}$ in pentane are stable for a short time period, while pure material immediately polymerizes at room temperature. Diluted solutions are stable for longer time periods at $-25^{\circ} \mathrm{C}$ (see SM for more details).

The instability of $\mathbf{1 3}$ led us to question its occurrence in nature. Injection of the PAs monocrotaline or lycopsamine into a GC/MS system with a heated split injector resulted in the formation of a small peak of 13. If the oxidized compounds monocrotaline $N$-oxide or monocrotaline pyrrole were injected, a larger amount of $\mathbf{1 3}$ was present. Therefore, it seems possible that $\mathbf{1 3}$ is produced during the injection of lycopsamine present in the extract in the injection port of the gas chromatograph, although the ratio of compounds $\mathbf{1 3}$ and $\mathbf{1}$ in the natural extract was significantly higher compared to the ratio obtained by the injection of pure alkaloids. Our experience with natural extracts showed that unstable compounds can survive a considerable 
amount of time when stored in cool conditions in mixtures. Therefore, although it may be possible that $\mathbf{1 3}$ is an artefact formed inside the GC/MS injection port, we cannot rule out that it is produced by $O$. onega and stored under stabilizing, non-oxidative conditions in their androconia to be used as a signal. These questions can only be resolved by bioassays, however, performing such bioassays is highly challenging due to the instability of pyrrolizine $\mathbf{1 3}$ and the difficult to rear ithomiine butterflies.

Identification of compounds $\boldsymbol{B}$ and $\boldsymbol{C}$. The mass spectra of acids $\mathbf{B}$ and $\mathbf{C}$ are shown in Figure 5. To improve elution properties, the extract was treated with diazomethane to convert free acids into their respective methyl esters (Figure 3b). Comparison with MS databases revealed compound $\mathbf{C}$ to be 9-hydroxynonanoic acid (21), while $\mathbf{B}$ seemed to be its unsaturated analog in light of similarities in the mass spectra (Figure 5), indicated e. g. by the 2 amu shift of the ions $\mathrm{m} / z$ 138, 144 and 158 to $m / z, 136,142$ and 156 in the spectra of both free acids and their methyl esters. Furthermore, the ion series $m / z 69,83, \ldots$ is shifted to $m / z 67,81, \ldots$ Treatment of the methylated extract with dimethyl disulfide (DMDS) and GC/MS analysis identified the location of the doublebonds in the unsaturated acids (see Figure S2, SM). Compound B proved to be 9-hydroxy-6nonenoic acid (18) since the position of the double-bond is indicated by the ions $\mathrm{m} / \mathrm{z} 105$ $\left[\mathrm{HOC}_{3} \mathrm{H}_{5} \mathrm{SCH}_{3}\right]^{+}, 175\left[\mathrm{C}_{8} \mathrm{H}_{15} \mathrm{O}_{2} \mathrm{~S}^{+}\right.$, and $143\left[\mathrm{C}_{8} \mathrm{H}_{15} \mathrm{O}_{2} \mathrm{~S}_{-} \mathrm{CH}_{3} \mathrm{OH}\right]^{+}$(Figure S2, SM) in the mass spectrum of the DMDS adduct. The methyl esters of the unsaturated fatty acids were similarly identified as methyl 11-hexadecenoate (characteristic ions $m / z \quad 117 \quad\left[\mathrm{C}_{5} \mathrm{H}_{11} \mathrm{SCH}_{3}\right]^{+}, \mathrm{m} / z 245$ $\left[\mathrm{C}_{12} \mathrm{H}_{22} \mathrm{O}_{2} \mathrm{SCH}_{3}\right]^{+}$and $\left.\mathrm{m} / z 213\left[245-\mathrm{CH}_{3} \mathrm{OH}\right]^{+}\right)$and methyl 9-hexadecenoate $(\mathrm{m} / \mathrm{z}$ 145, 217, 185) in a 95:5 mixture, as well as methyl 9-octadecenoate $(\mathrm{m} / \mathrm{z} 173,217,185)$, methyl 11-octadecenoate $(\mathrm{m} / \mathrm{z} 145,245,213)$ and methyl 13-octadecenoate $(\mathrm{m} / \mathrm{z} 117,273,241)$ in a 75:23:2 mixture (Figure S2, SM). 

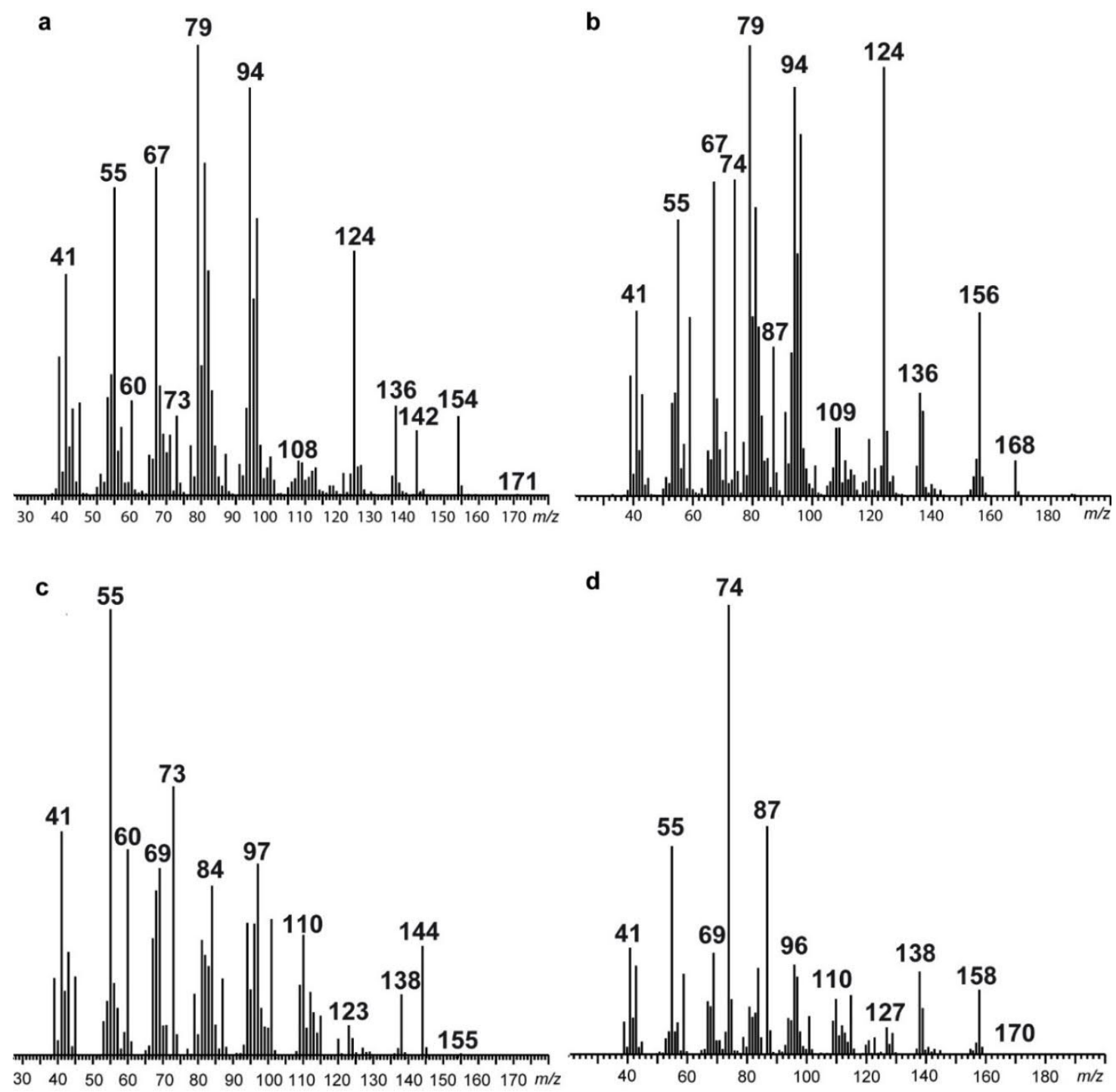

Fig. 5 Mass spectra of a) (Z)-9-hydroxynon-6-enoic acid (B, 18); b) methyl (Z)-9-hydroxynon-6enoate (23); c) 9-hydroxynonanoic acid $(\mathbf{C}, \mathbf{2 1})$; d) methyl 9-hydroxynonanoate (20)

Determination of the double-bond configuration of naturally occurring $\mathbf{B}$ was performed by comparison with synthetic material obtained according to Figure 6. 3-Butin-1-ol (15) was coupled with 5-bromopentanoic acid (16) according to Cossy and Pete 1986, followed by hydrogenation with Lindlar's catalyst to yield (Z)-9-hydroxy-6-nonenoic acid (18) (Johnson et al. 1982). For comparison, an E/Z-mixture of $\mathbf{1 8}$ was obtained by Wittig reaction of ethyl 6-oxohexanoate with 
3-hydroxypropylidenetriphenylphosphorane, followed by saponification (Scheme S1, SM). The synthetic acids were methylated and their retention index was compared to the methyl ester of $\mathbf{B}$. While the (E)-diastereomer showed $I$ 1475, the methyl ester of the natural compound B showed $I$ 1480 , identical to the one of the synthetic (Z)-diastereomer, thus confirming that B is actually identical to 18.
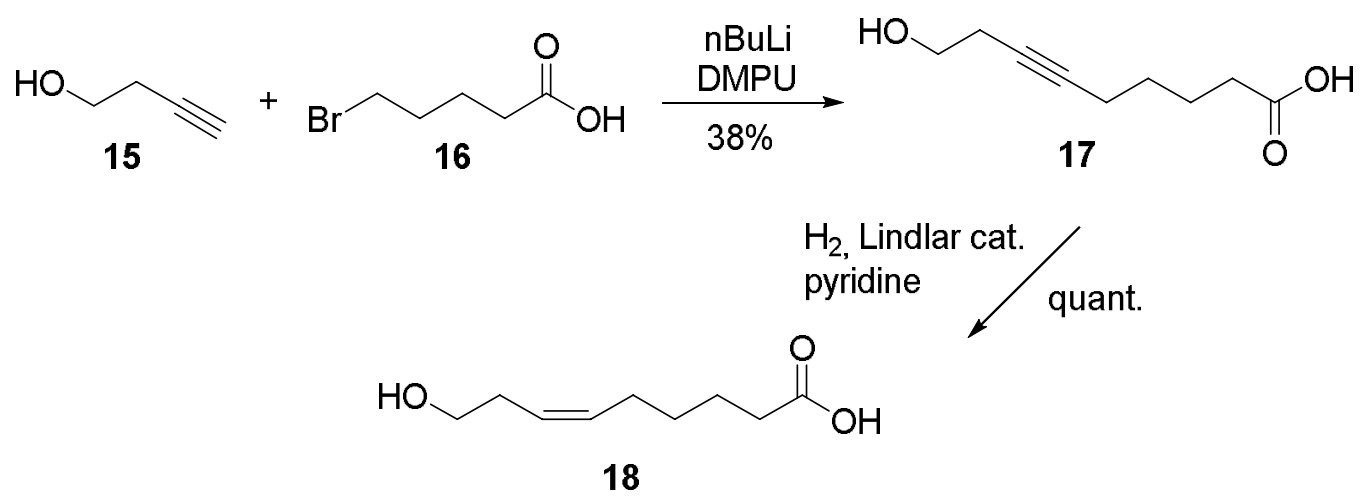

Fig. 6 Synthesis of (Z)-9-hydroxy-6-nonenoic acid (18)

Identification of compounds $\boldsymbol{D}$ and $\boldsymbol{E}$. Compounds $\mathbf{D}$ and $\mathbf{E}$ were readily identified as 6,10,14trimethylpentadecan-2-ol (D, 37), a known pheromone compound present in various Lepidoptera, including butterflies (Nesbitt et al. 1986; Nieberding et al. 2008; Kindl et al. 2012; Hedenström et al. 2014), and 2-heptadecanol (E, 39).

Identification of compounds $\boldsymbol{F}$ and $\boldsymbol{G}$. A group of compounds $(\mathbf{F}, \mathbf{G})$ eluted much later and were characterized by a poor peak shape (Figure 3a), indicating a functional group such as an alcohol, acid, or both. Their mass spectra combined spectral features of fatty acids and compounds $\mathbf{B}$ and C. Methylation transformed these compounds into methyl esters, showing their high content in the extract (Figure 3b). The mass spectrum of the methyl ester of compound $\mathbf{G}$ (Figure 7b) showed ions at $m / z 59,74$, and M-31, typical for methyl esters, and a strong ion group around $m / z 236$, indicating the presence of a hexadecenoyl chain. These data and the molecular ion at $\mathrm{m} / \mathrm{z}, 424$ 
indicated additionally a saturated $\mathrm{C}_{9}$-substructure in the compound. The indicative ion $\mathrm{m} / \mathrm{z} 171$ might be formed by cleavage of the internal C-O-C bond, an energetically non-favored process, or alternatively an unspecific $\mathrm{H}$-transfer from the $\mathrm{C}_{16}$-chain to the methoxycarbonyl group, followed by elimination of hexadecenoic acid similar to a McLafferty rearrangement. The charge would reside on the ion m/z 171 as indicated in Figure 5a. Additional loss of methanol leads to the ion $\mathrm{m} / \mathrm{z}$ 139. The DMDS adduct again confirmed the location of the double-bond at C-11 of the hexadecenoyl part (Figure S3, SM). In conclusion, these data confirm the identity of compound $\mathbf{G}$ to be 9-[(11-hexadecenoyl)oxy]nonanoic acid (31). 


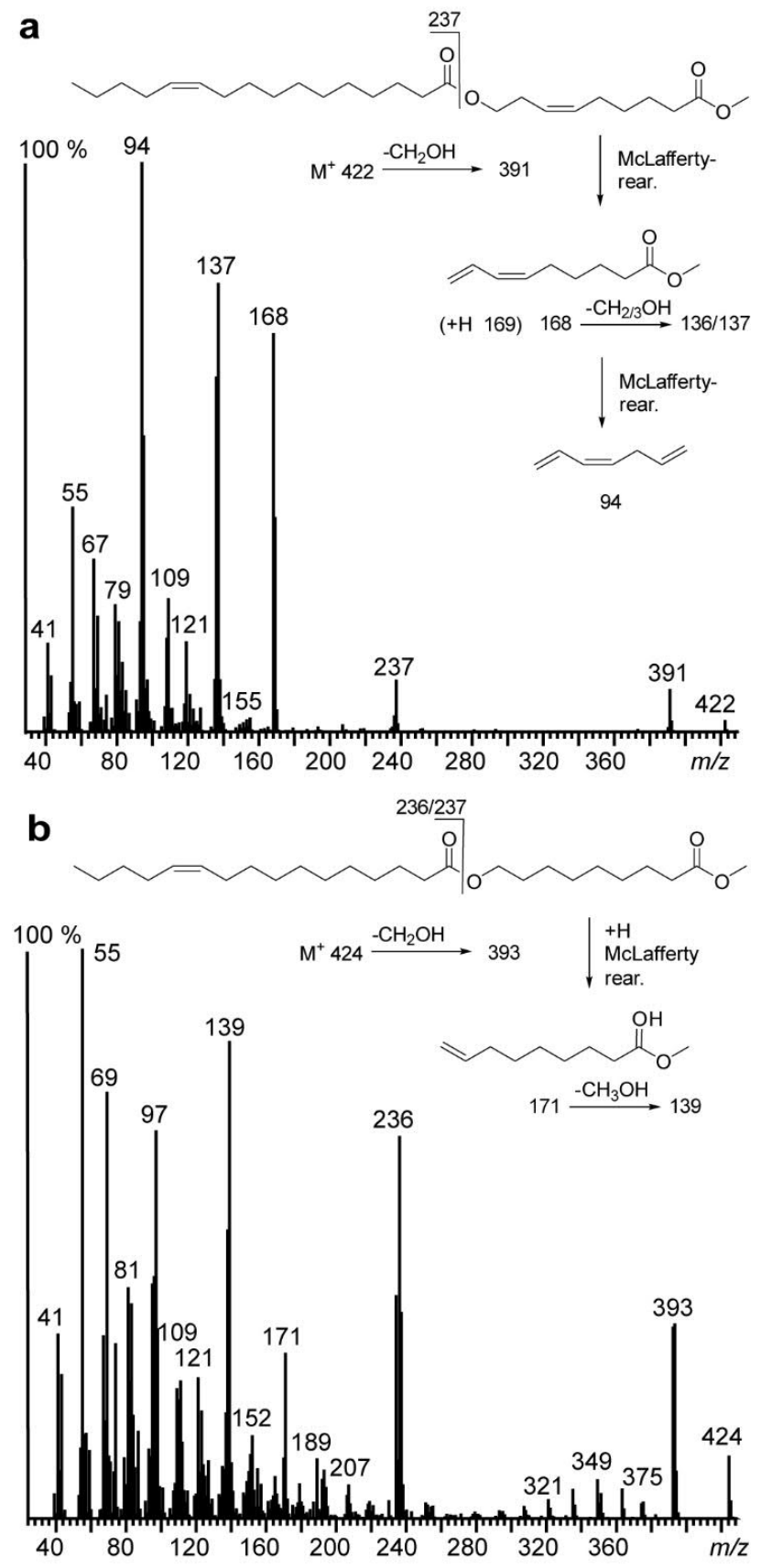

Fig. 7 Mass spectra and fragmentation of methyl esters of (a) F, 9-[(11-hexadecenoyl)oxy]-6nonenoic acid (32), and (b) G, 9-[(11-hexadecenoyl)oxy]nonanoic acid (31)

The mass spectrum of the methyl ester of compound $\mathbf{F}$ (Figure 7a) showed a molecular mass two amu lower than that of $\mathbf{G}$. The ion $\mathrm{m} / \mathrm{z} 237$ again indicated a hexadecenoyl side chain, thus 
placing the additional double-bond in the $\mathrm{C}_{9}$-part. We therefore tentatively identified compound $\mathbf{F}$ as 9-[(11-hexadecenoyl)oxy]-6-nonenoic acid (32), the condensation product of the two major acids in the androconia, $\mathbf{1 8}$ and 11-hexadecenoic acid. The respective octadecenoyl esters, e. g. $\mathbf{3 3}$ and 34, occurred in much lower quantities which prevented proper identification.

Identification of other ester acids. The hydroxy acids $\mathbf{B}$ and $\mathbf{C}$ were also found to serve as coupling partners, although the coupling products were not detected in the underivatized natural extract, likely because of the bad elution behavior of hydroxy acids in GC. Nevertheless, after methylation, the dimeric $\mathrm{C}_{9}$ methyl esters $\mathbf{M e - 3 5 - M e - 4 0}$ derived from the respective acids were identified based on their mass spectra (Figure 1b and Figure S4, SM). Their structures were assigned from specific ions (see Figure S4 for postulated fragmentation pathways), namely $\mathrm{m} / \mathrm{z}$ 157 (acyl fragment) and 138 which indicated a 9-hydroxynonanoyl unit present in $\mathbf{3 5}$ and $\mathbf{3 8}$. The ions $m / z 155$ (acyl), 136/137 (acyl- $\mathrm{H}_{2} \mathrm{O}$ ) are formed from 9-hydroxynon-6-enoyl residues in 36 and 40. Ion $m / z 124$ can be explained by McLafferty rearrangement to a hydroxyacid with $m / z$ 170, followed by loss of 46 amu, e.g. $\mathrm{H}_{2} \mathrm{O}$ and $\mathrm{CO}$. The quite stable ion $\mathrm{m} / \mathrm{z} 94 \mathrm{might}$ be formed by two consecutive McLafferty-rearrangements in case of methyl 9-acyloxynon-6-enoates $\mathbf{3 8}$ and $\mathbf{4 0 .}$

These proposals were verified by synthesis of the discussed compounds according to Figure 8 . The required building block (Z)-11-hexadecenoic acid (26) was obtained by Wittig-reaction of 11bromoundecanoic acid (25) with pentanal. Methyl 9-hydroxynonanoate (20) was synthesized by reduction with $\mathrm{BH}_{3}$ from monomethyl nonanedioate (19), while its reaction with $\mathrm{NaBH}_{4}$ delivered 9-hydroxynonanoic acid (21). Acid 18 was converted into methyl (Z)-6-nonenoate (23) by methylation with methyl iodide. Both hydroxy acids needed to be protected at the hydroxy group to avoid self-condensation. Therefore, $\mathbf{1 8}$ and $\mathbf{2 1}$ were protected as tert-butyldimethylsilyl ethers, compounds 22 and $\mathbf{2 4}$. The coupling of the different $\mathrm{C}_{9}$ and $\mathrm{C}_{16}$ properly protected building blocks 
was performed by esterification using EDC/DMAP. In case of the dimeric $\mathrm{C}_{9} / \mathrm{C}_{9}$ esters a final deprotection step was necessary. All synthesized esters proved to be identical to the methyl esters of the natural ester acids discussed. 


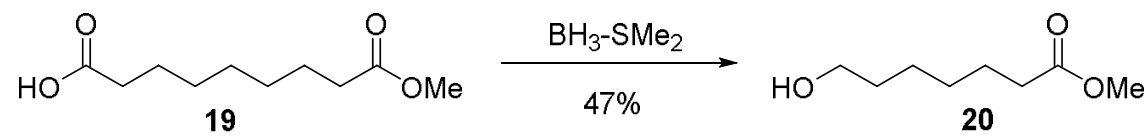
$\mathrm{NaBH}_{4} \downarrow 36 \%$

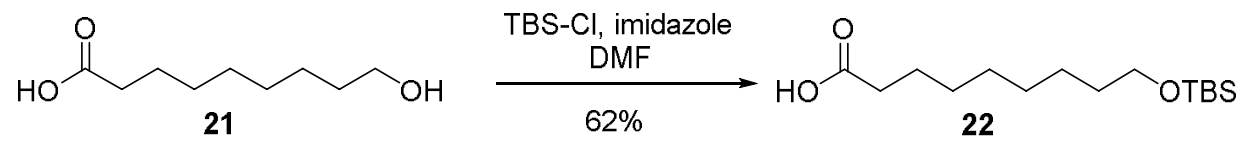<smiles>O=C(O)CCCC/C=C/CCO</smiles>

18

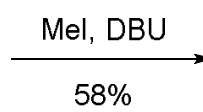<smiles>COC(=O)CCCC/C=C/CCO</smiles>

23

TBS-Cl

imidazole $65 \%$<smiles>[Z4]C/C=C\CCCCC(=O)O</smiles>

24

1) $\mathrm{PPh}_{3}$

2) NaHMDS<smiles>O=C(O)CCCCCCCCCCBr</smiles>

25

3) pentanal

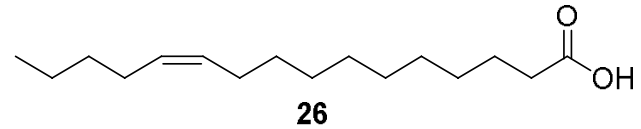

26

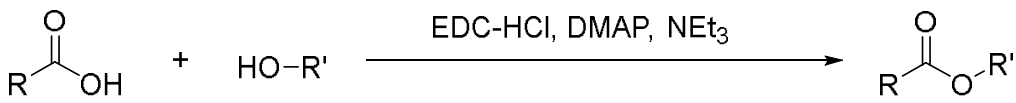

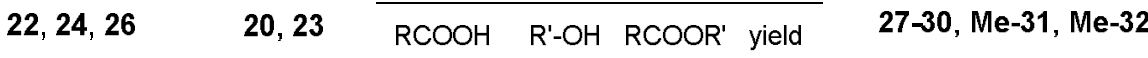

$\begin{array}{lccc}26 & \mathbf{2 0} & \text { Me-31 } & 94 \% \\ 26 & \mathbf{2 3} & \text { Me-32 } & 74 \% \\ 22 & \mathbf{2 0} & 27 & 80 \% \\ 22 & \mathbf{2 3} & 28 & 68 \% \\ 24 & \mathbf{2 0} & 29 & 61 \% \\ 24 & 23 & 30 & 61 \%\end{array}$

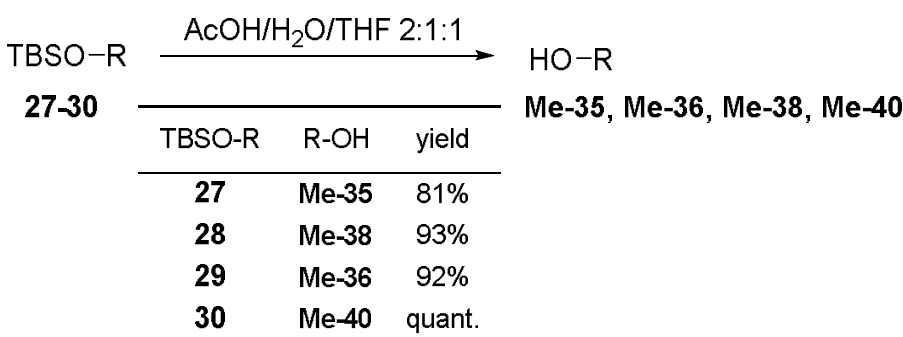

Fig. 8 Synthesis of the methyl esters of ester acids 31, 32, 35, 36, 38, and 40. Me-35: Methyl ester of 35 


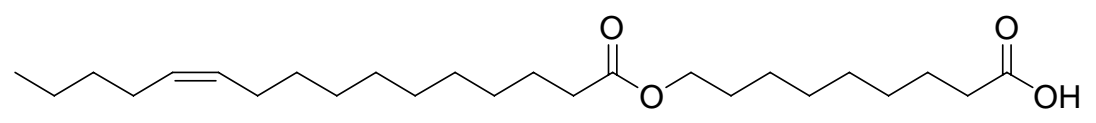

31

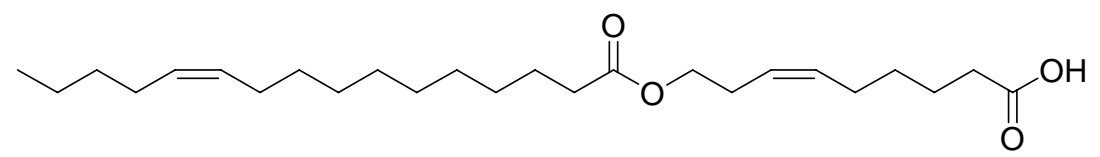

32

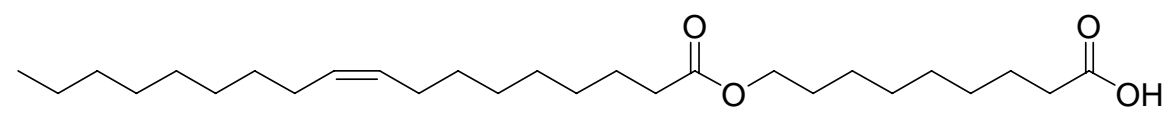

33<smiles>CCCCCCCC/C=C/CCCCCCCC(=O)OCC/C=C/CCCCC(=O)O</smiles>

34<smiles>O=C(O)CCCC/C=C/CCO</smiles>

18<smiles>O=C(O)CCCCCCCCO</smiles>

21

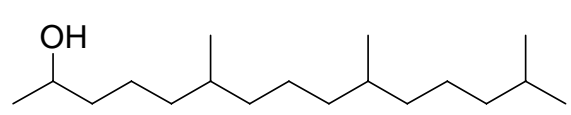

37<smiles>CCCCCCCCCCCCCCCC(C)O</smiles>

39<smiles>O=C(O)CCCCCCCCOC(=O)CCCCCCCCO</smiles>

35<smiles>O=C(O)CCCCCCCCOC(=O)CCCC/C=C/CCO</smiles>

36<smiles>O=C(O)CCCC/C=C/CCOC(=O)CCCCCCCCO</smiles>

38<smiles>O=C(O)CCCC/C=C/CCOC(=O)CCCC/C=C/CCO</smiles>

Fig. 9 Androconial compounds of Oleria onega janarilla

Androconia of another subspecies, $O$. onega spp. 3, contained almost the same compounds, including 13. Major differences were the lack of the two alcohols 37 and 39, and a higher 
proportion of $\mathbf{1 8}$ compared to $\mathbf{2 1}$. While O. onega janarilla showed a 2:1 ratio, this ratio was of 19:1 for $O$. onega spp. 3. The ratio between $\mathbf{1}$ and $\mathbf{1 3}$ was similar for both subspecies and was of 10:1. The structures of the compounds discussed are shown in Figure 9.

\section{DISCUSSION}

Our results clearly show that $O$. onega, despite access to PA-containing plants, cannot biosynthesize the common ithomiine semiochemicals of type 1,2 , or 3 , probably due to nonfunctional or absent enzymes. Instead, pyrrolizine $\mathbf{1 3}$ can be detected, but whether it is formed in nature remains unclear. Nevertheless, its heat-induced formation from PAs may hint towards an ecological role of this metabolite, e. g. as a short term signal. PAs, usually occurring as $N$-oxides in plants, are attractive to a wide range of insects including ithomiines when withering, although the pure alkaloids are non-volatile (Boppré 1986). PAs are sequestered from withering plants (Trigo et al. 1996) by the butterflies, before they are undergoing oxidative degradation. A plausible degradation process leading to $\mathbf{1 3}$ is shown in Figure 10. A PA (41) is first oxidized to its $N$-oxide 42. Elimination fo water leads to dihydropyrrolizine 43. Dihydropyrrolizines are highly reactive when they are substituted with two good leaving groups such as the acyloxy-groups in $\mathbf{4 3}$ (Mattocks et al. 1989; Schulz 2009) and degrade upon storage. The following sequential loss of the two acyloxy groups by elimination, e. g. via the sequence shown in Figure 10, leads to the pyrrolizine $\mathbf{1 3}$, a compound of high volatility. The elimination process might be autocatalytically enhanced by the basic PA itself. 
<smiles>[R]C(=O)OC1CCN2CC=C(COC(=O)F)C12</smiles>

41

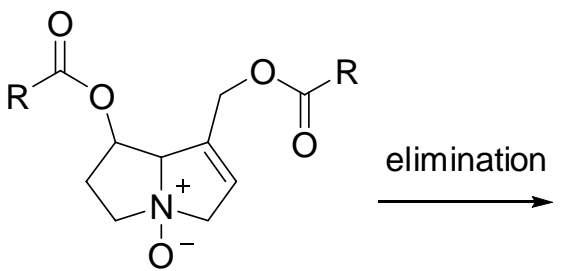

42<smiles>[R]C(=O)OCc1ccn2c1C(OC([R])=O)CC2</smiles>

43

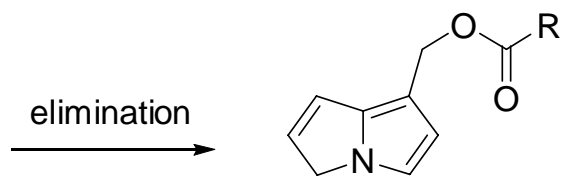

44
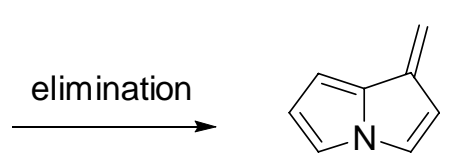

13

Fig. 10 Proposed mechanism for the formation of $\mathbf{1 3}$ from PAs through oxidative degradation

We can therefore consider the injection port of the GC as a rapid model for the elimination processes occurring during degradation in nature. Although a withering plant, an enzyme, and a GC injection port are hardly similar, the underlying chemistry might be. Therefore, it cannot be excluded that similar oxidation and elimination reactions might also occur enzymatically leading to the generation of $\mathbf{1 3}$ in Oleria.

Compound $\mathbf{1 3}$ may also serve as a reliable signal of PA degradation. Earlier experiments have suggested that hydroxydanaidal (2) is an PA derived compound attracting a wide range of Lepidoptera, and it was also suggested to be formed during degradation of PAs (Bogner and Boppré 1989). However, the identity of 2 was only proven by TLC and our own experiments with withered PAs have never confirmed its presence in any sample (Wegener 2002). Nevertheless, an unstable compound such as $\mathbf{1 3}$, formed continuously under oxidative conditions, is perfectly fitted to serve as a signal because of its short lifespan.

Instead of the known PA derivatives, $O$. onega may use 13 and/or non-PA-related compounds as signals. Primary candidates are the two alcohols $\mathbf{3 7}$ and 39, previously found in other insects, 
as well as the unique acids $\mathbf{1 8}$ and $\mathbf{2 1}$. In addition to these compounds, the occurrence of large amounts of 11-hexadecenoic and 11-octadecenoic acid is unusual, because oleic is the common unsaturated fatty acid present in insects. The $\Delta 11$-desaturase needed for their formation is the most common desaturase involved in pheromone production in Lepidoptera (Jurenka 2004), primarily in moth, but has also been found in the butterfly Bicyclus (Liénard et al. 2014).

The saturated acid $\mathbf{2 1}$ has previously been reported in insects as a component of royal jelly (Lercker et al. 1981), but is not known to be used in communication by insects, while the unsaturated acid $\mathbf{1 8}$ is only reported as a product of genetically modified Escherichia coli, formed by Bayer-Villiger-oxidation from $\gamma$-linolenic acid (Kim et al. 2015). Terminally oxidized acids with medium chain length are not uncommon as insect pheromones, e. g. in honey bees and other hymenoptera (Pankiw et al. 1998; Ayasse et al. 2003). All ester acids 31, 32, 35, 36, 38, and 40 have not been reported before from nature. While fatty acid esters are commonly found in butterfly scent glands and ithomiines (Mann 2016), the ester acids represent a new class of insect metabolites. Whether they are formed as by-products of hydroxy acid formation or serve a certain purpose, e. g. as fixatives or attachment material is unclear.

In summary, we showed that $O$. onega is not able to produce dihydropyrrolizines or lactones derived from PAs, in striking contrast to most other ithomiines. Furthermore, we identified unique short-chain terminally oxidized acids and their condensation product as new natural compounds. Whether 1-methylene-1H-pyrrolizine (13), synthesized for the first time, is involved in the chemical communication of this butterfly remains unclear. However, this puts into question the current practice of focusing solely on stable compounds in the study of chemical communication systems. 
Acknowledgments- We thank Stephanie Gallusser for the live Oleria onega janarilla photo and Céline Houssin for the Oleria onega photos in the SM. We thank the Peruvian authorities and Dr. Gerardo Lamas (Museo de Historia Natural, Universidad Mayor de San Marcos) for research permits (002-2015-SERFOR-DGGSPFFS) and PEHCBM-Area de Conservacion Regional Cordillera Escalera (023-2016/GRSM/PEHCBM/DMA/ACR-CE). We thank the Deutsche Forschungsgemeinschaft (DFG) (Schu 984/12-1) and the French National Agency for Research (ANR) through the project SPECREP (grant number ANR-14-CE02-0011 awarded to ME and employing MM as a postdoc) for financial support.

Supplementary Material. Butterfly images, mass spectra, NMR spectra, IR spectrum, synthetic procedures, stability of $\mathbf{1 3}(\mathrm{PDF})$.

\section{REFERENCES}

Ayasse M, Schiestl FP, Paulus HF, Ibarra F, Francke W (2003) Pollinator attraction in a sexually deceptive orchid by means of unconventional chemicals. Proc R Soc B Biol Sci 270:517-522

Bogner F, Boppré M (1989) Single cell recordings reveal hydroxydanaidal as the volatile compound attracting insects to pyrrolizidine alkaloids. Entomol Exp Appl 50:171-184

Boppré M (1986) Insects Pharmacophagously Utilizing Defensive Plant Chemicals (Pyrrolizidine Alkaloids). Naturwissenschaften 73:17-26

Brandänge S, Lundin C (1971) A synthesis of endo- and exo-1-Ethoxycarbonyl-pyrrolizidine. Acta Chem Scand 25:2447-2450

Chazot N, Willmott KR, Lamas G, Freitas AVL, Piron-Prunier F, Arias CF, Mallet J, De-Silva DL, Elias M (2019) Renewed diversification following Miocene landscape turnover in a Neotropical butterfly radiation. Global Ecol Biogeogr:Early online 
Cossy J, Pete JP (1986) A one step synthesis of $\omega$-hydroxyacetylenic carboxylic acids. Tetrahedron Lett 27:573-574

Dasmahapatra KK, Lamas G, Simpson F, Mallet J (2010) The anatomy of a 'suture zone' in Amazonian butterflies: A coalescent-based test for vicariant geographic divergence and speciation. Mol Ecol 19:4283-4301

De-Silva DL, Vásquez AS, Mallet J (2011) Selection for enemy-free space - Eggs placed away from the host plant increase survival of a neotropical ithomiine butterfly. Ecol Entomol $36: 667-672$

Edgar JA, Culvenor CCJ, Pliske TE (1976) Isolation of a lactone, structurally related to the esterifying acids of pyrrolizidine alkaloids, from the coastal fringes of male Ithomiinae. J Chem Ecol 2:263-270

Eisner T, Meinwald J (1995) The chemistry of sexual selection. Proc Natl Acad Sci USA 92:5055

Fashe MM, Juvonen RO, Petsalo A, Rahnasto-Rilla M, Auriola S, Soininen P, Vepsäläinen J, Pasanen M (2014) Identification of a New Reactive Metabolite of Pyrrolizidine Alkaloid Retrorsine: (3H-Pyrrolizin-7-yl)methanol. Chem Res Toxicol 27:1950-1957

Hedenström E, Wallin EA, Andersson J, Bång J, Wang H-L, Löfstedt C, Brattström O, Baquet P (2014) Stereoisomeric Analysis of 6,10,14-Trimethylpentadecan-2-ol and the Corresponding Ketone in Wing Extracts from African Bicyclus Butterfly Species. J Chem Ecol 41:44-51

Honda Y, Honda K, Omura H (2006) Major components in the hairpencil secretion of a butterfly, Euploea mulciber (Lepidoptera, Danaidae): Their origins and male behavioral responses to pyrrolizidine alkaloids. J Insect Physiol 52:1043-1053 
Jefford CW, Thornton SR, Sienkiewicz K (1994) An enantiospecific entry to indolizidines by intramolecular acylation of $N$-pyrrole esters. Tetrahedron Lett 35:3905-3908

Johnson F, Paul KG, Favara D (1982) An efficient synthesis of methyl dl-cis-jasmonate. J Org Chem 47:4254-4255

Jurenka R (2004) Insect Pheromone Biosynthesis. The Chemistry of Pheromones and Other Semiochemicals I, Top. Curr. Chem. 239. Springer, Berlin

Kim S, Kang S, Kim G, Lee Y (2016) Copper-Catalyzed Aza-Michael Addition of Aromatic Amines or Aromatic Aza-Heterocycles to $\alpha, \beta$-Unsaturated Olefins. J Org Chem 81:4048-4057

Kim S-U, Kim K-R, Kim J-W, Kim S, Kwon Y-U, Oh D-K, Park J-B (2015) Microbial synthesis of plant oxylipins from $\gamma$-linolenic acid through designed biotransformation pathways. J Agric Food Chem 63:2773-2781

Kindl J, Jiros P, Kalinova B, Zacek P, Valterova I (2012) Females of the Bumblebee Parasite, Aphomia sociella, Excite Males Using a Courtship Pheromone. J Chem Ecol 38:400-407

Lercker G, Capella P, Conte LS, Ruini F, Giordani G (1981) Components of royal jelly I. Identification of the organic acids. Lipids 16:912-919

Liénard MA, Wang H-L, Lassance J-M, Löfstedt C (2014) Sex pheromone biosynthetic pathways are conserved between moths and the butterfly Bicyclus anynana. Nat Commun 5:3957

Mann F (2016) Die Diversität von Pheromonen in Schmetterlingen der Familie Nymphalidae. PhD thesis. TU Braunschweig, Braunschweig

Mattocks AR, Jukes R, Brown J (1989) Simple Procedures for preparing putative toxic metabolites of pyrrolizidine alkaloids. Toxicon 27:561-567 
Nesbitt BF, Beevor PS, Cork A, Hall DR, David H, Nandagopal V (1986) The female sex pheromone of sugarcane stalk borer, Chilo auricilius. Identification of four components and field tests. J Chem Ecol 12:1377-1388

Neuenschwander M (2015) Low-Temperature Olefin Syntheses in View of Parent Fulvenes and Fulvalenes. Helv Chim Acta 98:731-762

Nieberding CM, Vos H de, Schneider MV, Lassance J-M, Estramil N, Andersson J, Bång J, Hedenström E, Löfstedt C, Brakefield PM, Somers M (2008) The Male Sex Pheromone of the Butterfly Bicyclus anynana: Towards an Evolutionary Analysis. PLoS One 3:e2751

Pankiw T, Huang ZY, Winston ML, Robinson GE (1998) Queen mandibular gland pheromone influences worker honey bee (Apis mellifera L.) foraging ontogeny and juvenile hormone titers. J Insect Physiol 44:685-692

Schulz S (1992) Absolute Configuration and Synthesis of 2-Hydroxy-2-(1-hydroxyethyl)-3methyl- $\gamma$-butyrolactone, a Presumed Pheromone of Ithomiine Butterflies. Liebigs Ann Chem:829-834

Schulz S (1998) Insect-Plant Interactions --- Metabolism of plant compounds to pheromones and allomones by Lepidoptera and Leaf Beetles. Eur J Org Chem:13-20

Schulz S (2009) Alkaloid-Derived Male Courtship Pheromones, in Conner WE (ed.). Tiger moths and woolly bears: Behavior, ecology, and evolution of the Arctiidae. Univ. Press, Oxford, pp. $145-153$

Schulz S, Beccaloni G, Brown jr. KS, Boppré M, Freitas AVL, Ockenfels P, Trigo JR (2004) Semiochemicals derived from pyrrolizidine alkaloids in male ithomiine butterflies (Lepidoptera: Nymphalidae Ithomiinae). Biochem Syst Ecol 32:699-713 
Schulz S, Francke W, Boppré M, Eisner T, Meinwald J (1993) Insect pheromone biosynthesis: Stereochemical pathway of hydroxydanaidal production from alkaloidal precursors in Creatonotos transiens (Lepidoptera, Arctiidae). Proc Natl Acad Sci USA 90:6834-6838

Schulz S, Francke W, Edgar JA, Schneider D (1988) Volatile Compounds from Androconial Organs of Danaine and Ithomiine Butterflies. Z Naturforsch Sect C J Biosci 43c:99-104

Trigo JR, Barata LES, Brown jr. KS (1994) Stereochemical Inversion of Pyrrolizidine Alkaloids by Mechanitis polymnia (Lepidoptera: Nymphalidae: Ithomiinae): Specificity and Evolutionary Significance. J Chem Ecol 20:2883-2899

Trigo JR, Brown jr. KS, Witte L, Hartmann T, Ernst L, Barata LES (1996) Pyrrolizidine Alkaloids: different acquisition and use patterns in Apocynaceae and Solanaceae feeding ithomiine butterflies (Lepidoptera: Nymphalidae). Biol J Linn Soc 58:99-123

van den Dool H, Kratz P (1963) A generalization of the retention index system including linear temperature programmed gas-liquid partition chromatography. J Chromatogr 11:463-471

Wegener R (2002) Identifizierung und Synthese von Inhaltsstoffen aus Blattkäfern und Pflanzen mit biologischer Aktivität in tritrophischen Systemen. PhD thesis. TU Braunschweig, Braunschweig 
Supporting material for

\section{Chemistry of the Androconial Secretion of the Ithomiine Butterfly Oleria onega}

Patrick Stamm, ${ }^{1}$ Florian Mann, ${ }^{1}$ Melanie McClure,${ }^{2}$ Marianne Elias, ${ }^{2}$ and Stefan Schulz ${ }^{1, *}$

${ }^{1}$ Institute of Organic Chemistry, TU Braunschweig, Hagenring 30, 38106 Braunschweig, e-mail: stefan.schulz@tu-bs.de

${ }^{2}$ Institut Systématique Evolution Biodiversité, Centre National de la Recherche Scientifique, MNHN, Sorbonne Université, EPHE, Université des Antilles, 57 rue Cuvier, CP 50, 75005

Paris, France

\section{Contents}

1. Butterflies 2

2. Mass Spectra 3

3. Synthetic Scheme $\quad 7$

4. Synthetic Procedures 7

5. Stability of 1-Methylene-1 $H$-pyrrolizine (13) 21

6. NMR and IR Spectra 22

7. References 25 


\section{Butterflies}
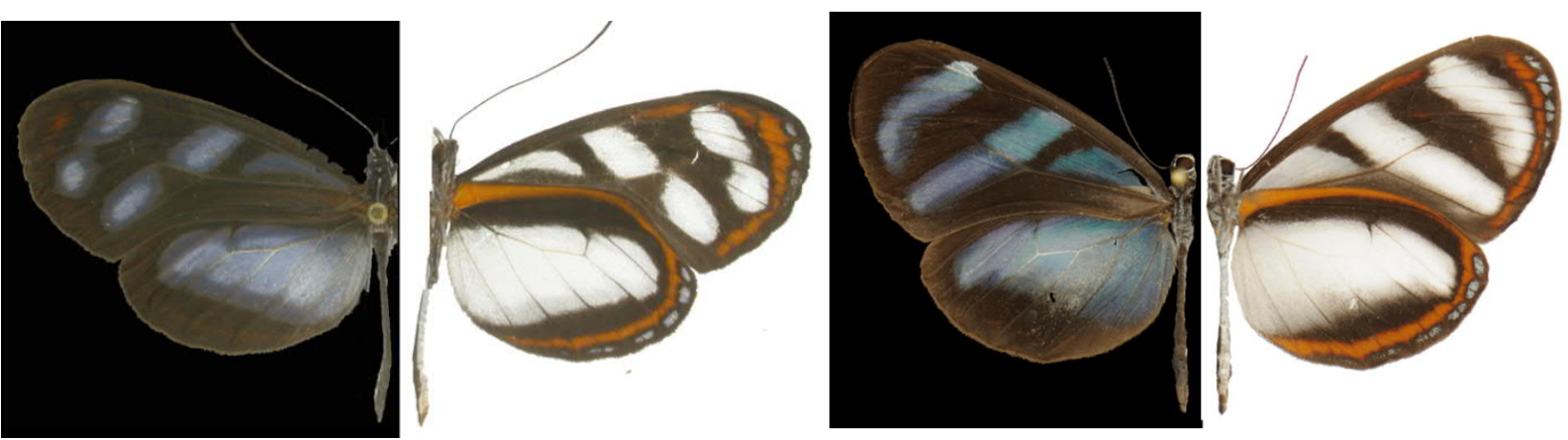

Figure S1. Oleria onega janarilla (left) from lowland north-eastern Peru and O. onega ssp. nov. 3 (right) from Andean foothills in the province of San Martin (De-Silva et al. 2011). The dorsal side is shown on the left of each photo, against a dark background to highlight transparency of the wings, and the ventral side is shown on the right of each photo, against a white background. The two subspecies can be differentiated by their wing color pattern, which is more melanic in the forewing of O. onega janarilla. Although a formal description of $O$. onega ssp. nov. 3 has not been published, this subspecies is well characterized and has been the focus of several publications (Dasmahapatra et al. 2010; De-Silva et al. 2011). 


\section{Mass Spectra}
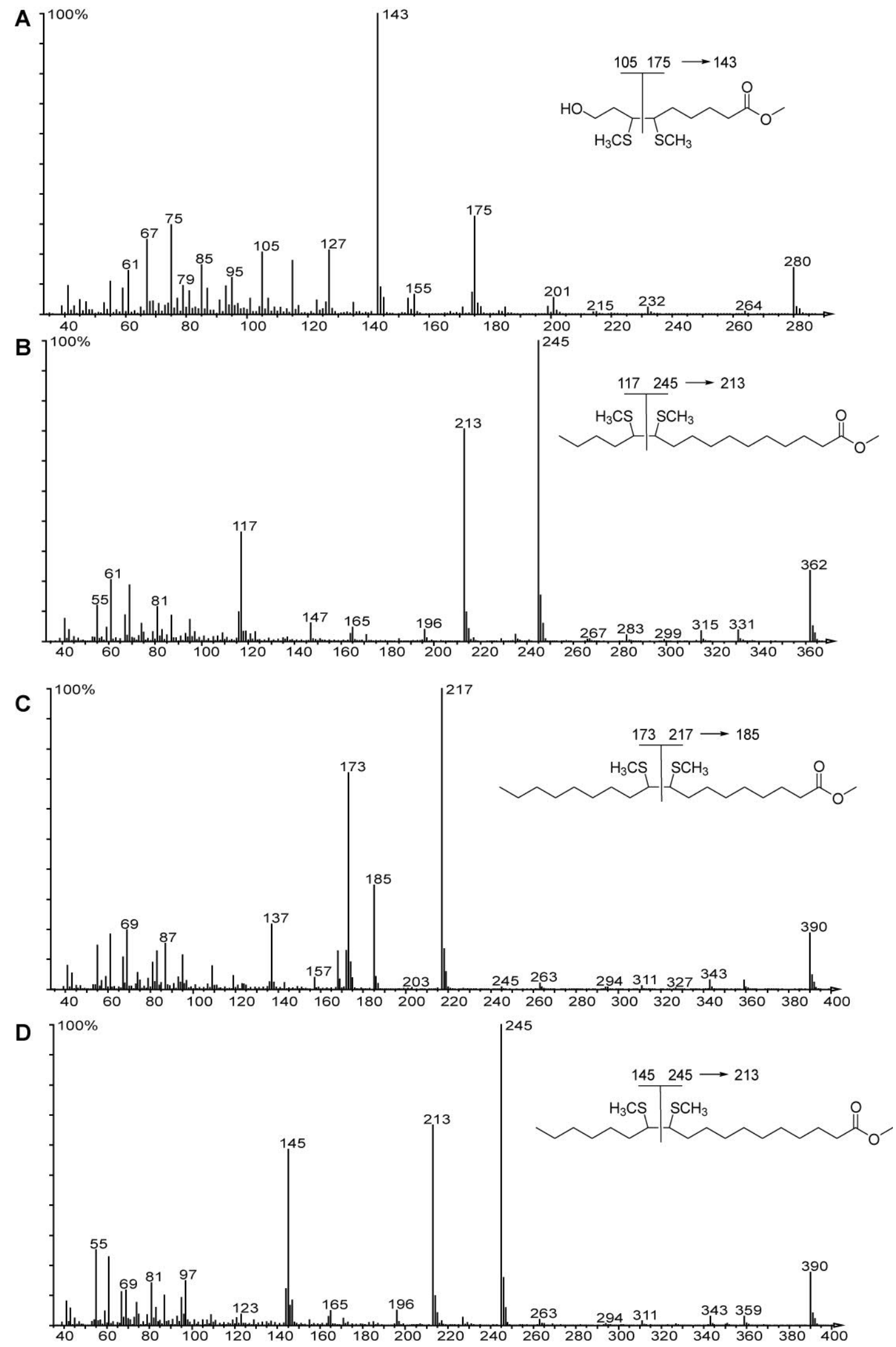

Figure S2. Dimethyl disulfide adducts of A) methyl (Z)-9-hydroxynonen-6-oate; B) methyl 11hexadecenoate; C) methyl 9-octadecenoate; D) methyl 11-octadecenoate and formation of diagnostic ions. 


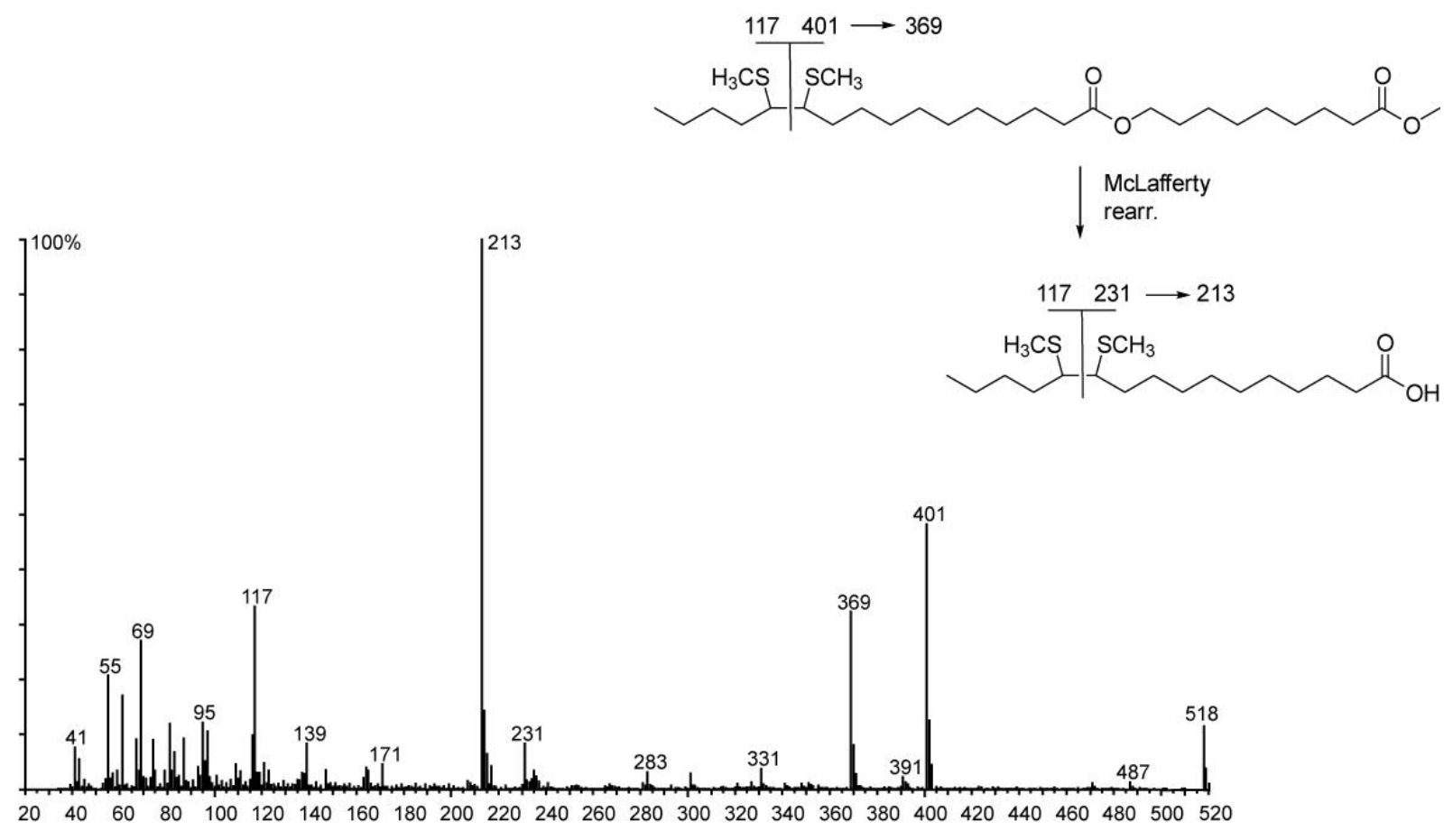

Figure S3. Dimethyl disulfide adduct of methyl ( $Z$ )-9-[(11-hexadecenoyl)oxy]non-6-enoate. 
a

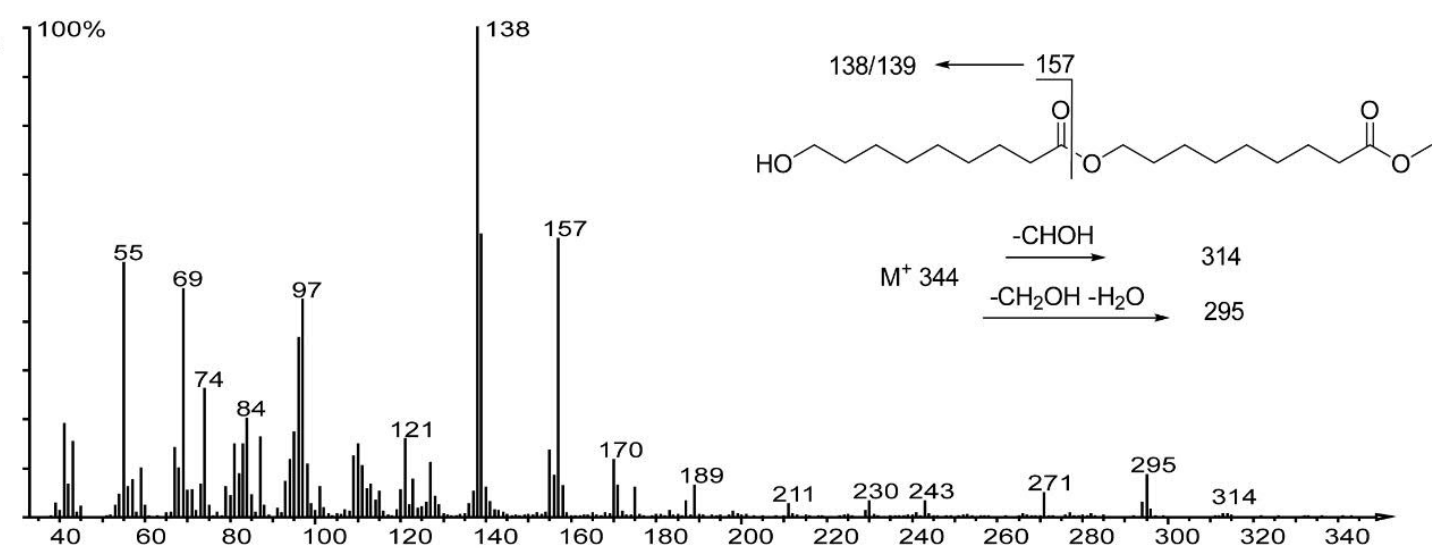

b

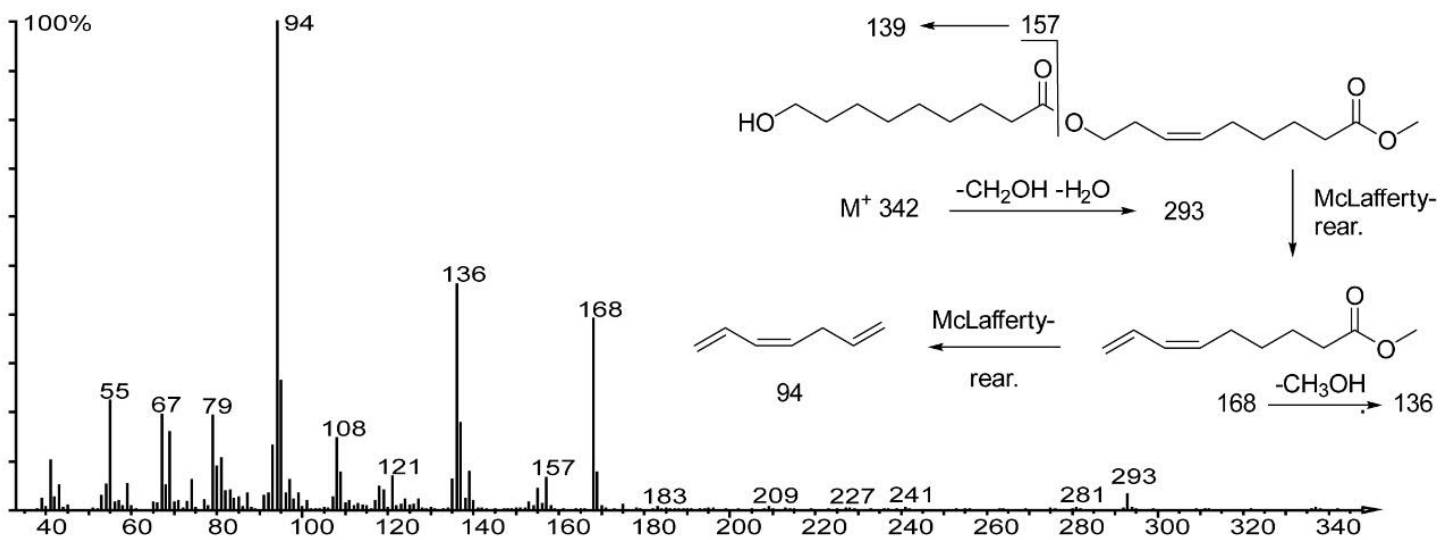

c

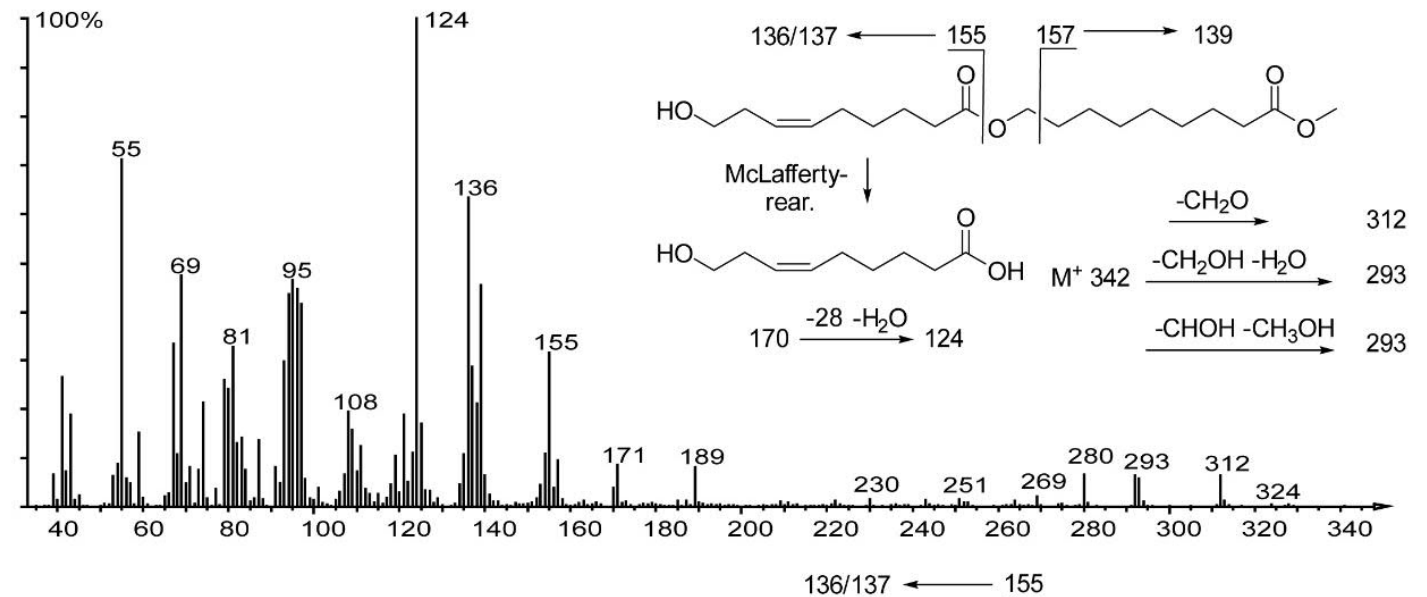

d

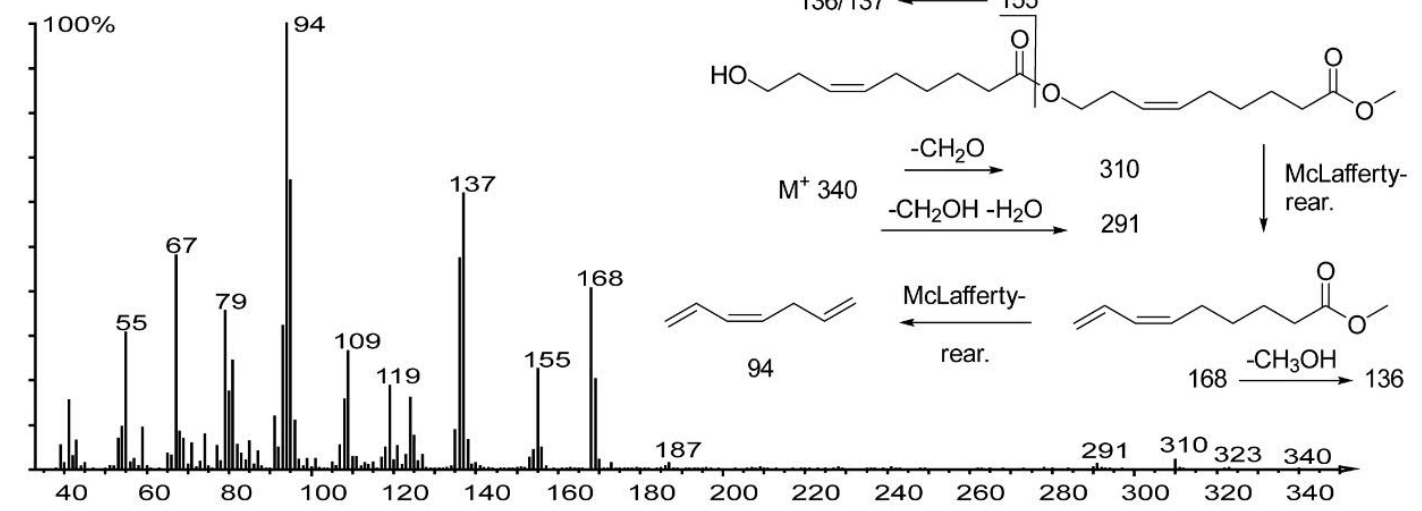

Figure S4. Mass spectra and fragmentation of a) Methyl 9-[(9-hydroxynonanoyl)oxy]nonanoate ( Me35); b) methyl (Z)-9-[(9-hydroxynon-6-enoyl)oxy]nonanoate (Me-38); c) methyl (Z)-9-[(9hydroxynonanoyl)oxy]non-6-enoate (Me-36); d) methyl (Z)-9-[((Z)-9-hydroxynon-6-enoyl)oxy]non-6enoate (Me-40). 

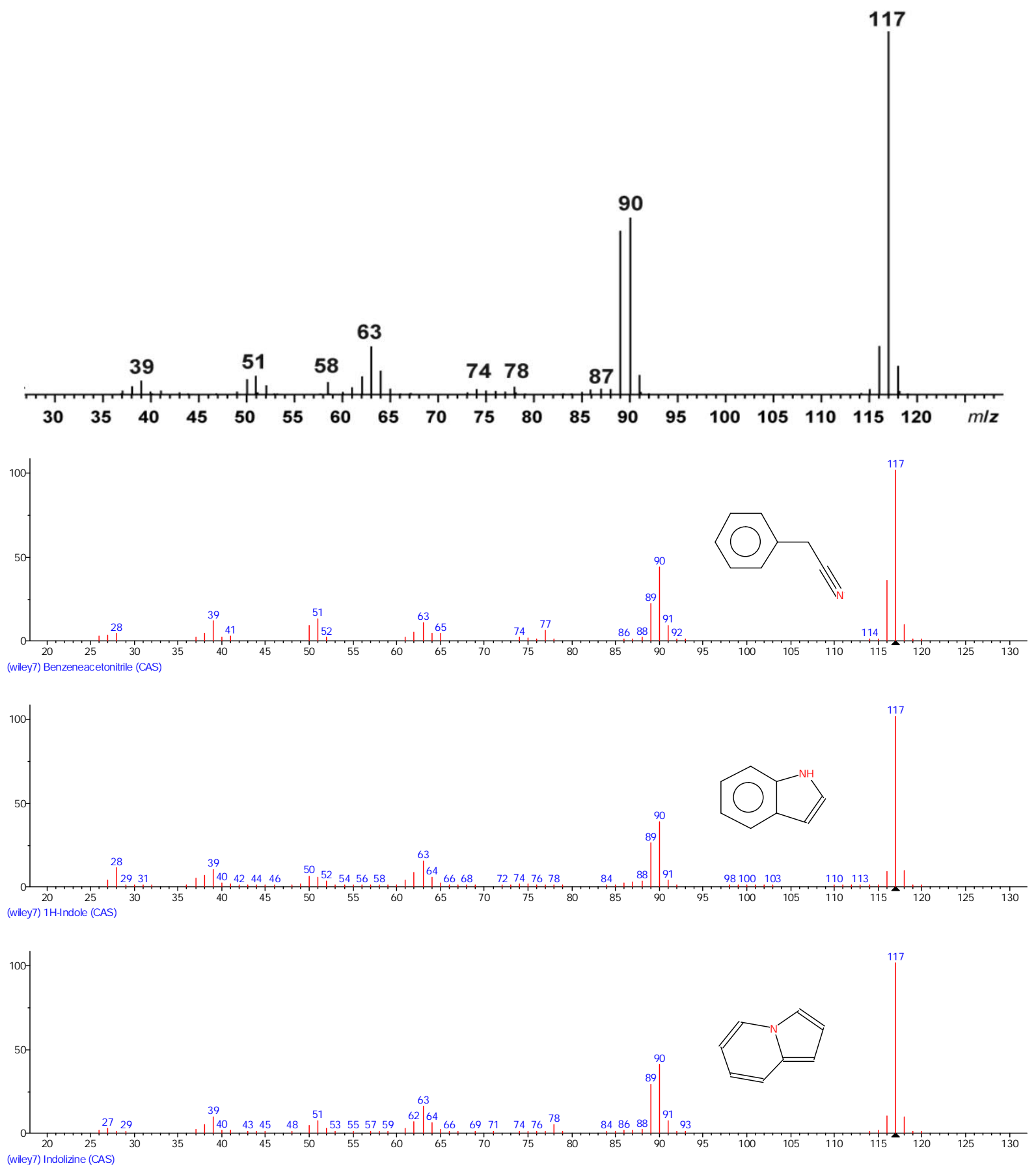

Figure S5: Mass spectra of (from top to bottom) compound A, benzyl cyanide, indole, and indolizine. 


\section{Synthetic Scheme}

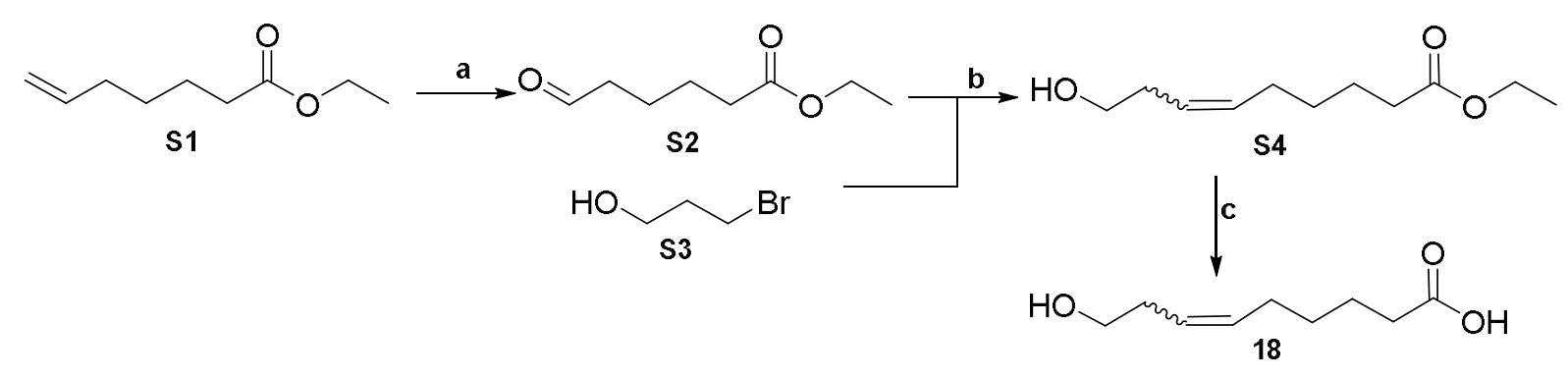

E/Z2:1

Scheme S1: a) $\mathrm{K}_{2} \mathrm{OsO}_{4}, \mathrm{NaIO}_{4}, 1: 1 \mathrm{H}_{2} \mathrm{O}: \mathrm{Et}_{2} \mathrm{O}, 12 \mathrm{~h} \mathrm{rt}, 83 \%$; b) i) $\mathbf{S 3}, \mathrm{PPh}_{3}$, toluene, $3 \mathrm{~h} 110{ }^{\circ} \mathrm{C}, 57$ $\%$; ii) LDA, THF, 1 h $0{ }^{\circ} \mathrm{C}$; iii) S2, THF, $12 \mathrm{~h}-78{ }^{\circ} \mathrm{C}, 42 \%$; c) KOH, ethanol, $24 \mathrm{~h} \mathrm{rt}, 84 \%$

\section{Synthetic Procedures}

\section{Ethyl 6-oxohexanoate (S2)}<smiles>CCOC(=O)CCCCC=O</smiles>

Potassium osmate ( $40 \mathrm{mg}, 0.1 \mathrm{mmol}, 0.16$ equiv) was added to ethyl 6-heptenoate $(1.00 \mathrm{~g}$, $6.4 \mathrm{mmol}, 1$ equiv) in diethyl ether $(20 \mathrm{~mL})$ and water $(20 \mathrm{~mL})$ and the resulting mixture was vigorously stirred for $10 \mathrm{~min}$. Sodium periodate $(2.74 \mathrm{~g}, 12.8 \mathrm{mmol}, 2$ equiv) was added over $30 \mathrm{~min}$ and the reaction mixture was vigorously stirred for further $12 \mathrm{~h}$ (Pappo et al. 1956). Water was added, the phases were separated and the aqueous layer was extracted three times with diethyl ether. The combined organic layers were washed with sat. aq. $\mathrm{NaCl}$, dried with $\mathrm{MgSO}_{4}$, filtered and concentrated in vacuo. The crude product was purified by column chromatography on silica (pentane/diethyl ether 2:1) to yield ethyl 6-oxohexanoate ( $\mathbf{S 2}$ ): colorless liquid $(0.83 \mathrm{~g}, 5.3 \mathrm{mmol}, 83 \%)$.

$R_{f}=0.35$ (pentane/diethyl ether 2:1);

UV/Vis $\left(\mathrm{CH}_{2} \mathrm{Cl}_{2}\right) \lambda_{\max }(\log \varepsilon) 227$ (1.74), 291 (0.64);

IR (neat) $v_{\max } 2982,2941,2872,2826,2724,1723,1436,1372,1181,1154,1095,1031,858$;

${ }^{1} \mathrm{H} \mathrm{NMR}\left(\mathrm{CDCl}_{3}, 400 \mathrm{MHz}\right) \delta 9.77(1 \mathrm{H}, \mathrm{t}, J=1.7 \mathrm{~Hz}, \mathrm{CH}), 4.13\left(2 \mathrm{H}, \mathrm{q}, J=7.1 \mathrm{~Hz}, \mathrm{CH}_{2}\right)$, 2.50-2.43 (2H, m, $\left.\mathrm{CH}_{2}\right), 2.36-2.28\left(2 \mathrm{H}, \mathrm{m}, \mathrm{CH}_{2}\right), 1.69-1.64\left(4 \mathrm{H}, \mathrm{m}, 2 \mathrm{CH}_{2}\right), 1.26(3 \mathrm{H}, \mathrm{t}, J=$ $\left.7.1 \mathrm{~Hz}, \mathrm{CH}_{3}\right)$;

${ }^{13} \mathrm{C} \mathrm{NMR}\left(100 \mathrm{MHz}, \mathrm{CDCl}_{3}\right) \delta 202.0(\mathrm{CH}), 173.2(\mathrm{C}), 60.3\left(\mathrm{CH}_{2}\right), 43.5\left(\mathrm{CH}_{2}\right), 34.0\left(\mathrm{CH}_{2}\right)$, $24.4\left(\mathrm{CH}_{2}\right), 21.5\left(\mathrm{CH}_{2}\right), 14.2\left(\mathrm{CH}_{3}\right)$; 
EIMS $m / z 158\left(0.1,[\mathrm{M}]^{+}\right), 140(0.4), 130$ (24), 115 (50), 113 (92), 101 (100), 95 (20), 88 (37), 84 (43), 73 (87), 67 (88), 55 (86), 41 (68).

\section{Ethyl 9-hydroxynon-6-enoate (S4)}

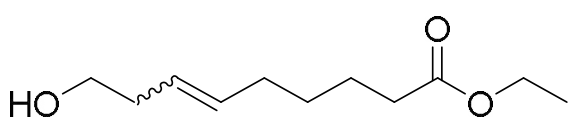

To a solution of triphenylphosphine (3.77 g, $14.4 \mathrm{mmol}, 1$ equiv) in toluene (18 $\mathrm{mL})$ was added 3-bromo-1-propanol (S3, $4.00 \mathrm{~g}, 24.8 \mathrm{mmol}, 2$ equiv). The reaction mixture was heated to reflux for $3 \mathrm{~h}$ and cooled to $0^{\circ} \mathrm{C}$. The precipitating Wittig salt (3hydroxypropyl)triphenylphosphonium bromide was filtered and washed three times with toluene: white solid (3.28 g, $8.20 \mathrm{mmol}, 57 \%$ ) (Page et al. 2003).

$n$-Butyllithium (1.6 M in hexane, $3.8 \mathrm{~mL}, 6.0 \mathrm{mmol}, 2.4$ equiv) was added dropwise at $-78^{\circ} \mathrm{C}$ to a solution of diisopropylamine $(658 \mathrm{mg}, 6.5 \mathrm{mmol}, 2.6$ equiv) in dry THF $(10 \mathrm{~mL})$. The resulting lithium diisopropylamide (LDA) solution was stirred for $15 \mathrm{~min}$ and added to a suspension of (3-hydroxypropyl)triphenylphosphonium bromide (1.12 g, $2.78 \mathrm{mmol}$, 1.1 equiv) in dry $\mathrm{THF}(30 \mathrm{~mL})$ at $0^{\circ} \mathrm{C}$. The red reaction mixture was cooled to $-78^{\circ} \mathrm{C}$ after stirring for $1 \mathrm{~h}$ and a solution of $\mathbf{S 2}$ (400 mg, $2.50 \mathrm{mmol}, 1$ equiv) in dry THF (2.5 mL) was slowly added. The reaction mixture was stirred for $12 \mathrm{~h}$ at $-78^{\circ} \mathrm{C}$. Water was added, the phases were separated and the aqueous layer was extracted three times with diethyl ether. The combined organic layers were washed with sat. aq. $\mathrm{NaCl}$, dried with $\mathrm{MgSO}_{4}$, filtered and concentrated in vасио. The crude product was purified by column chromatography on silica (pentane/diethyl ether 3:1) to yield ethyl 9-hydroxynon-6-enoate ( S4) as a diastereomeric mixture: colorless liquid (210 mg, $2.05 \mathrm{mmol}, 42 \%)$.

$(E) /(Z)=63: 37(\mathrm{GC} / \mathrm{MS})$

$R_{f}=0.30$ (pentane/diethyl ether 3:1);

UV/Vis (acetonitrile) $\lambda_{\max }(\log \varepsilon) 192(3.73)$;

IR (neat) $v_{\max } 3435,2934,2866,1733,1461,1373,1180,1044,969$;

(E)-diastereomer: ${ }^{1} \mathrm{H} \mathrm{NMR}\left(\mathrm{CDCl}_{3}, 600 \mathrm{MHz}\right) \delta 5.54(1 \mathrm{H}, \mathrm{dtt}, J=15.3,6.7,1.0 \mathrm{~Hz},=\mathrm{CH})$, $5.40(1 \mathrm{H}, \mathrm{dtt}, J=15.3,6.9,1.2 \mathrm{~Hz},=\mathrm{CH}), 4.13\left(2 \mathrm{H}, \mathrm{q}, J=7.1 \mathrm{~Hz}, \mathrm{CH}_{2}\right), 3.63(2 \mathrm{H}, \mathrm{t}, J=6.2 \mathrm{~Hz}$, $\left.\mathrm{CH}_{2}\right), 2.29\left(2 \mathrm{H}, \mathrm{t}, J=7.5 \mathrm{~Hz}, \mathrm{CH}_{2}\right), 2.26\left(2 \mathrm{H}\right.$, br q, $\left.J=6.2 \mathrm{~Hz}, \mathrm{CH}_{2}\right), 2.04(2 \mathrm{H}$, br q, $J=6.7 \mathrm{~Hz}$, $\left.\mathrm{CH}_{2}\right), 1.63\left(2 \mathrm{H}\right.$, quint, $\left.J=7.8 \mathrm{~Hz}, \mathrm{CH}_{2}\right), 1.43-1.37\left(2 \mathrm{H}, \mathrm{m}, \mathrm{CH}_{2}\right), 1.26\left(3 \mathrm{H}, \mathrm{t}, J=7.1 \mathrm{~Hz}, \mathrm{CH}_{3}\right)$;

${ }^{13} \mathrm{C} \mathrm{NMR}\left(150 \mathrm{MHz}, \mathrm{CDCl}_{3}\right) \delta 173.8(\mathrm{C}), 133.5(\mathrm{CH}), 126.4(\mathrm{CH}), 62.0\left(\mathrm{CH}_{2}\right), 60.2\left(\mathrm{CH}_{2}\right)$, $36.0\left(\mathrm{CH}_{2}\right), 34.1\left(\mathrm{CH}_{2}\right), 32.2\left(\mathrm{CH}_{2}\right), 28.8\left(\mathrm{CH}_{2}\right), 24.4\left(\mathrm{CH}_{2}\right), 14.2\left(\mathrm{CH}_{3}\right)$;

EIMS m/z 182 (7), 170 (50), 154 (7), 137 (40), 124 (100), 119 (23), 109 (21), 101 (22), 96 (83), 94 (74), 88 (48), 81 (81), 79 (91), 67 (84), 60 (21), 55 (80), 41 (60); 
(Z)-diastereomer: ${ }^{1} \mathrm{H}$ NMR $\left(\mathrm{CDCl}_{3}, 600 \mathrm{MHz}\right) \delta 5.57-5.52(1 \mathrm{H}, \mathrm{m},=\mathrm{CH}), 5.41-5.37(1 \mathrm{H}, \mathrm{m}$, $=\mathrm{CH}), 4.13\left(2 \mathrm{H}, \mathrm{q}, J=7.1 \mathrm{~Hz}, \mathrm{CH}_{2}\right), 3.65\left(2 \mathrm{H}, \mathrm{t}, J=6.4 \mathrm{~Hz}, \mathrm{CH}_{2}\right), 2.32(2 \mathrm{H}, \mathrm{br} \mathrm{q}, J=6.7 \mathrm{~Hz}$, $\left.\mathrm{CH}_{2}\right), 2.30\left(2 \mathrm{H}, \mathrm{t}, J=7.5 \mathrm{~Hz}, \mathrm{CH}_{2}\right), 2.09\left(2 \mathrm{H}\right.$, br q, $\left.J=7.4 \mathrm{~Hz}, \mathrm{CH}_{2}\right), 1.63(2 \mathrm{H}$, quint, $J=$ $\left.7.5 \mathrm{~Hz}, \mathrm{CH}_{2}\right), 1.43-1.37\left(2 \mathrm{H}, \mathrm{m}, \mathrm{CH}_{2}\right), 1.26\left(3 \mathrm{H}, \mathrm{t}, J=7.1 \mathrm{~Hz}, \mathrm{CH}_{3}\right)$;

${ }^{13} \mathrm{C} \mathrm{NMR}\left(150 \mathrm{MHz}, \mathrm{CDCl}_{3}\right) \delta 173.7(\mathrm{C}), 132.7(\mathrm{CH}), 125.6(\mathrm{CH}), 62.3\left(\mathrm{CH}_{2}\right), 60.2\left(\mathrm{CH}_{2}\right)$, $34.2\left(\mathrm{CH}_{2}\right), 30.8\left(\mathrm{CH}_{2}\right), 29.1\left(\mathrm{CH}_{2}\right), 26.9\left(\mathrm{CH}_{2}\right), 24.5\left(\mathrm{CH}_{2}\right), 14.2\left(\mathrm{CH}_{3}\right)$;

EIMS m/z 182 (6), 170 (42), 154 (13), 137 (29), 124 (96), 119 (19), 109 (22), 101 (24), 96 (85), 94 (84), 88 (50), 81 (82), 79 (100), 67 (93), 60 (23), 55 (88), 41 (72).

9-Hydroxynon-6-enoic acid (18)<smiles>O=C(O)CCCCC=CCCO</smiles>

A solution of potassium hydroxide $(30 \mathrm{mg}, 0.54 \mathrm{mmol}, 3$ equiv) in water $(0.10 \mathrm{~mL})$ and ethanol $(0.14 \mathrm{~mL})$ was added dropwise to a solution of ethyl 9-hydroxynon-6-enoate $(\mathbf{S 4}, 37 \mathrm{mg}$, $0.18 \mathrm{mmol}, 1$ equiv) in ethanol $(0.28 \mathrm{~mL})$ at $0^{\circ} \mathrm{C}$. The reaction mixture was warmed to $\mathrm{rt}$ and stirred for $24 \mathrm{~h}$. Ethanol was removed in vacuo and the remaining aqueous residue was diluted with sat. aq. $\mathrm{NaCl}$, washed two times with diethyl ether, acidified to $\mathrm{pH} 4$ with $1 \mathrm{~N}$ aq. $\mathrm{NaHSO}_{4}$ and extracted four times with ethyl acetate (Mori and Kisida 1986). The combined ethyl acetate extracts were dried with $\mathrm{MgSO}_{4}$, filtered and concentrated in vacuo to yield 9-hydroxynon-6enoic acid (18) as a diastereomeric mixture: colorless liquid (26 mg, $0.15 \mathrm{mmol}, 84 \%$ ).

$(E) /(Z)=66: 33(\mathrm{NMR})$;

$R_{f}=0.24\left(\mathrm{CH}_{2} \mathrm{Cl}_{2} /\right.$ methanol 15:1);

UV/Vis $\left(\mathrm{CH}_{2} \mathrm{Cl}_{2}\right) \lambda_{\max }(\log \varepsilon) 227$ (2.22);

IR (neat) $v_{\max } 3300,2933,2652,1705,1413,1227,1194,1044,969$;

(E)-diastereomer: ${ }^{1} \mathrm{H} \mathrm{NMR}\left(\mathrm{CDCl}_{3}, 600 \mathrm{MHz}\right) \delta 5.53(1 \mathrm{H}, \mathrm{dtt}, J=15.3,6.7,1.1 \mathrm{~Hz},=\mathrm{CH})$, $5.40(1 \mathrm{H}, \mathrm{dtt}, J=15.3,6.9,1.4 \mathrm{~Hz},=\mathrm{CH}), 3.64\left(2 \mathrm{H}, \mathrm{t}, J=6.3 \mathrm{~Hz}, \mathrm{CH}_{2}\right), 2.35(2 \mathrm{H}, \mathrm{t}, J=7.5 \mathrm{~Hz}$, $\left.\mathrm{CH}_{2}\right), 2.27\left(2 \mathrm{H}\right.$, br q, $\left.J=6.5 \mathrm{~Hz}, \mathrm{CH}_{2}\right), 2.05\left(2 \mathrm{H}\right.$, br q, $\left.J=7.1 \mathrm{~Hz}, \mathrm{CH}_{2}\right), 1.64$ (2H, quint, $J=$ $\left.7.6 \mathrm{~Hz}, \mathrm{CH}_{2}\right), 1.43\left(2 \mathrm{H}\right.$, quint, $\left.J=7.6 \mathrm{~Hz}, \mathrm{CH}_{2}\right)$;

${ }^{13} \mathrm{C} \mathrm{NMR}\left(150 \mathrm{MHz}, \mathrm{CDCl}_{3}\right) \delta 179.3(\mathrm{C}), 133.5(\mathrm{CH}), 126.4(\mathrm{CH}), 62.0\left(\mathrm{CH}_{2}\right), 35.8\left(\mathrm{CH}_{2}\right)$, $33.8\left(\mathrm{CH}_{2}\right), 32.6\left(\mathrm{CH}_{2}\right), 28.7\left(\mathrm{CH}_{2}\right), 24.1\left(\mathrm{CH}_{2}\right)$;

EIMS m/z 154 (12), 142 (13), 136 (18), 124 (55), 96 (67), 94 (78), 81 (84), 79 (100), 73 (16), 67 (78), 60 (24), 55 (80), 41 (61);

(Z)-diastereomer: see below. 
Methyl 9-hydroxynonanoate (20)

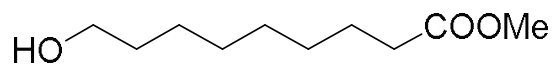

Borane-dimethylsulfide-complex (2 M solution in THF, $2.47 \mathrm{~mL}, 4.94 \mathrm{mmol}, 1$ equiv.) was added dropwise to a solution of monomethyl azelate (19, $1.00 \mathrm{~g}, 4.94 \mathrm{mmol}, 1$ equiv.) in THF $(10 \mathrm{~mL})$ at $-18^{\circ} \mathrm{C}$ (Yoon et al. 1973). The reaction mixture was allowed to slowly warm to room temperature over night. Water $(3.4 \mathrm{~mL})$ was added at $0^{\circ} \mathrm{C} . \mathrm{K}_{2} \mathrm{CO}_{3}(1.4 \mathrm{~g})$ was added, the organic layer was separated and the aqueous layer was extracted three times with diethyl ether. The combined organic layers were washed with sat. aq. $\mathrm{NaCl}$, dried with $\mathrm{MgSO}_{4}$, filtered and concentrated under reduced pressure. The residue was purified by column chromatography on silica (pentane/diethyl ether 1:2) to yield alcohol 20: colorless liquid (0.44 g, 2.34 mmol, 47\%).

$R_{\mathrm{f}}=0.30$ (pentane/diethyl ether 1:2);

IR (neat) $v_{\max } 3373$ (br), 2928 (s), 2856 (m), 1736 (s), 1438 (m), 1362 (w), 1198 (m), 1170 (s), $1103(\mathrm{w}), 1052(\mathrm{~m}), 879(\mathrm{w}), 724(\mathrm{w}) \mathrm{cm}^{-1}$;

${ }^{1} \mathrm{H}$ NMR $\left(\mathrm{CDCl}_{3}, 300 \mathrm{MHz}\right) \delta 3.67\left(3 \mathrm{H}, \mathrm{s}, \mathrm{CH}_{3}\right), 3.64\left(2 \mathrm{H}, \mathrm{t}, J=6.6 \mathrm{~Hz}, \mathrm{CH}_{2}\right), 2.30(2 \mathrm{H}, \mathrm{t}, J$ $\left.=7.5 \mathrm{~Hz}, \mathrm{CH}_{2}\right), 1.66-1.51\left(5 \mathrm{H}, \mathrm{m}, 2 \mathrm{CH}_{2}, \mathrm{OH}\right), 1.38-1.28\left(8 \mathrm{H}, \mathrm{m}, 4 \mathrm{CH}_{2}\right)$;

${ }^{13} \mathrm{C} \mathrm{NMR}\left(\mathrm{CDCl}_{3}, 75 \mathrm{MHz}\right) \delta 174.3(\mathrm{C}), 63.0\left(\mathrm{CH}_{2}\right), 51.4\left(\mathrm{CH}_{3}\right), 34.1\left(\mathrm{CH}_{2}\right), 32.7\left(\mathrm{CH}_{2}\right), 29.2$ $\left(2 \mathrm{CH}_{2}\right), 29.0\left(\mathrm{CH}_{2}\right), 25.6\left(\mathrm{CH}_{2}\right), 24.9\left(\mathrm{CH}_{2}\right)$;

EIMS m/z 158 (15), 138 (19), 127 (6), 115 (13), 110 (13), 101 (9), 96 (21), 87 (52), 84 (21), 74 (100), 69 (27), 59 (21), 55 (3), 43 (25), 41 (30);

$I(\mathrm{HP} 5-\mathrm{MS})=1499$.

\section{9-Hydroxynonanoic acid (21)}

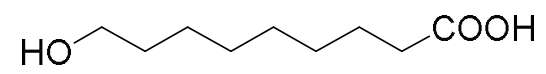

Sodium borohydride (1.30 g, $29.1 \mathrm{mmol}, 5.9$ equiv.) was added in portions to a solution of monomethyl azelate $(19,1.00 \mathrm{~g}, 4.94 \mathrm{mmol}, 1$ equiv.) in water $(12.5 \mathrm{~mL})$ and dioxane (12.5 mL) (Hinman and Richards 2018). The turbid reaction mixture was stirred over night at room temperature and was then hydrolyzed at $0^{\circ} \mathrm{C}$ by addition of $1 \mathrm{M}$ aq. $\mathrm{HCl}$. The solution was extracted three times with $\mathrm{CH}_{2} \mathrm{Cl}_{2}$ and the combined organic layers were dried with $\mathrm{MgSO}_{4}$ and concentrated under reduced pressure. The residue was purified by column chromatography on silica (pentane/diethyl ether 1:2) to yield hydroxyacid 21: colorless solid (0.31 g, $1.78 \mathrm{mmol}$, $36 \%)$. 
$R_{\mathrm{f}}=0.10$ (pentane/diethyl ether 1:1);

IR (neat) $v_{\max } 3402(\mathrm{w}), 3336(\mathrm{w}), 3200-2500(\mathrm{br}), 2926(\mathrm{~m}), 2853(\mathrm{~m}), 1689(\mathrm{~s}), 1432(\mathrm{w})$, 1368 (w), 1295 (m), 1262 (m), 1222 (m), 1193 (m), $1056(\mathrm{~s}), 976$ (w), $918(\mathrm{~m}), 725(\mathrm{w}), 636$ (m) $\mathrm{cm}^{-1}$;

${ }^{1} \mathrm{H} \mathrm{NMR}\left(\mathrm{CDCl}_{3}, 300 \mathrm{MHz}\right) \delta 5.08(2 \mathrm{H}$, br s, $2 \mathrm{OH}), 3.65\left(2 \mathrm{H}, \mathrm{t}, J=6.6 \mathrm{~Hz}, \mathrm{CH}_{2}\right), 2.35(2 \mathrm{H}$, $\left.\mathrm{t}, J=7.5 \mathrm{~Hz}, \mathrm{CH}_{2}\right), 1.69-1.51\left(4 \mathrm{H}, \mathrm{m}, 2 \mathrm{CH}_{2}\right), 1.41-1.29\left(8 \mathrm{H}, \mathrm{m}, 4 \mathrm{CH}_{2}\right)$;

${ }^{13} \mathrm{C} \mathrm{NMR}\left(\mathrm{CDCl}_{3}, 75 \mathrm{MHz}\right) \delta 179.1(\mathrm{C}), 63.0\left(\mathrm{CH}_{2}\right), 33.9\left(\mathrm{CH}_{2}\right), 32.7\left(\mathrm{CH}_{2}\right), 29.1\left(2 \mathrm{CH}_{2}\right)$, $28.9\left(\mathrm{CH}_{2}\right), 25.6\left(\mathrm{CH}_{2}\right), 24.6\left(\mathrm{CH}_{2}\right)$.

\section{9-[(tert-Butyldimethylsilyl)oxy]nonanoic acid (22)}

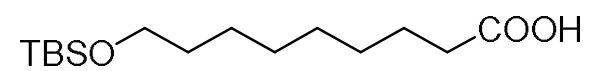

Imidazole ( $0.29 \mathrm{~g}, 4.27 \mathrm{mmol}, 2.4$ equiv.) was added to a solution of 9-hydroxynonanoic acid (21, $0.31 \mathrm{~g}, 1.78 \mathrm{mmol}, 1$ equiv.) in DMF (5 mL) (Aguilar et al. 2014). After stirring for $10 \mathrm{~min}$, tert-butyldimethylsilyl chloride $(0.35 \mathrm{~g}, 2.31 \mathrm{mmol}, 1.3$ equiv. $)$ was added and the reaction mixture was left over night at room temperature. The solution was concentrated under reduced pressure. The residue was dissolved in water $(6 \mathrm{~mL})$ and extracted three times with ethyl acetate. The combined organic layers were dried with $\mathrm{MgSO}_{4}$, filtered and concentrated under reduced pressure. The crude product was purified by column chromatography on silica (pentane/diethyl ether 1:1) to yield acid 22: colorless liquid (0.32 g, $1.11 \mathrm{mmol}, 62 \%)$.

$R_{\mathrm{f}}=0.67$ (pentane/diethyl ether $\left.1: 1\right)$;

IR (neat) $v_{\max }$ 3300-2500 (br), $2929(\mathrm{~m}), 2857$ (m), 1709 (s), $1466(\mathrm{w}), 1413(\mathrm{w}), 1252$ (m), 1097 (s), 937 (w), 834 (s), 774 (s), $720(\mathrm{w}), 663(\mathrm{w}) \mathrm{cm}^{-1}$;

${ }^{1} \mathrm{H} \mathrm{NMR}\left(\mathrm{CDCl}_{3}, 300 \mathrm{MHz}\right) \delta 3.59\left(2 \mathrm{H}, \mathrm{t}, J=6.6 \mathrm{~Hz}, \mathrm{CH}_{2}\right), 2.35\left(2 \mathrm{H}, \mathrm{t}, J=7.5 \mathrm{~Hz}, \mathrm{CH}_{2}\right)$, 1.69-1.45 (4H, m, $\left.2 \mathrm{CH}_{2}\right), 1.37-1.26\left(8 \mathrm{H}, \mathrm{m}, 4 \mathrm{CH}_{2}\right), 0.89\left(9 \mathrm{H}, \mathrm{s}, 3 \mathrm{CH}_{3}\right), 0.05\left(6 \mathrm{H}, \mathrm{s}, 2 \mathrm{CH}_{3}\right)$;

${ }^{13} \mathrm{C} \mathrm{NMR}\left(\mathrm{CDCl}_{3}, 75 \mathrm{MHz}\right) \delta 180.0(\mathrm{C}), 63.3\left(\mathrm{CH}_{2}\right), 34.0\left(\mathrm{CH}_{2}\right), 32.8\left(\mathrm{CH}_{2}\right), 29.2\left(2 \mathrm{CH}_{2}\right)$, $29.9\left(\mathrm{CH}_{2}\right), 26.0\left(3 \mathrm{CH}_{3}\right), 25.7\left(\mathrm{CH}_{2}\right), 24.7\left(\mathrm{CH}_{2}\right), 18.4(\mathrm{C}),-5.3\left(2 \mathrm{CH}_{3}\right)$.

\section{9-Hydroxynon-6-ynoic acid (17)}

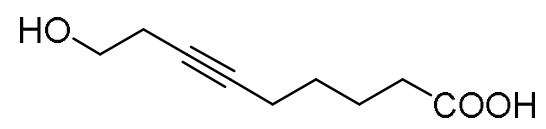

n-Butyllithium (1.6 M solution in hexanes) was added dropwise to a solution of 3-butyn-1-ol (15, $1.0 \mathrm{~mL}, 13.2 \mathrm{mmol}, 2$ equiv.) in DMPU $(9.6 \mathrm{~mL})$ and THF $(20 \mathrm{~mL})$ at $-80^{\circ} \mathrm{C}$ (Cossy and 
Pete 1986). The turbid reaction mixture was allowed to warm to $-30^{\circ} \mathrm{C}$ over $1 \mathrm{~h}$ and stirred for $45 \mathrm{~min}$ at this temperature. Then, 5-bromopentanoic acid (16, $1.20 \mathrm{~g}, 6.61 \mathrm{mmol}, 1$ equiv.) in THF ( $2 \mathrm{~mL}$ ) was added dropwise. The reaction mixture was warmed to room temperature and stirred for $20 \mathrm{~h} .1 \mathrm{M}$ aq. $\mathrm{HCl}$ was added and the mixture was extracted three times with ethyl acetate. The combined organic layers were washed with sat. aq. $\mathrm{NaCl}$, dried over $\mathrm{MgSO}_{4}$, filtered and concentrated under reduced pressure. The residue was purified two times by column chromatography on silica (pentane/diethyl ether 1:2 and pentane/diethyl ether 1:4 with $0.2 \%$ $\mathrm{AcOH})$ to yield hydroxyacid 17: colorless solid (0.43 g, $2.53 \mathrm{mmol}, 38 \%)$.

$R_{\mathrm{f}}=0.40$ (diethyl ether);

IR (neat) $v_{\max }$ 3600-2400 (br), 2935 (m), 1704 (s), 1417 (m), 1313 (m), 1259 (m), 1202 (m), $1040(\mathrm{~s}), 906(\mathrm{~m}), 731(\mathrm{w}), 675(\mathrm{~m}) \mathrm{cm}^{-1}$;

${ }^{1} \mathrm{H} \mathrm{NMR}\left(\mathrm{CDCl}_{3}, 300 \mathrm{MHz}\right) \delta 6.11(2 \mathrm{H}$, br s, $2 \mathrm{OH}), 3.69\left(2 \mathrm{H}, \mathrm{t}, J=6.2 \mathrm{~Hz}, \mathrm{CH}_{2}\right), 2.46-2.40$ $\left(2 \mathrm{H}, \mathrm{m}, \mathrm{CH}_{2}\right), 2.39\left(2 \mathrm{H}, \mathrm{t}, J=7.3 \mathrm{~Hz}, \mathrm{CH}_{2}\right), 2.24-2.18\left(2 \mathrm{H}, \mathrm{m}, \mathrm{CH}_{2}\right), 1.80-1.70\left(2 \mathrm{H}, \mathrm{m}, \mathrm{CH}_{2}\right)$, 1.61-1.51 (2H, m, $\left.\mathrm{CH}_{2}\right)$;

${ }^{13} \mathrm{C} \mathrm{NMR}\left(\mathrm{CDCl}_{3}, 75 \mathrm{MHz}\right) \delta 179.1(\mathrm{C}), 81.8(\mathrm{C}), 77.0(\mathrm{C}), 61.3\left(\mathrm{CH}_{2}\right), 33.4\left(\mathrm{CH}_{2}\right), 28.1\left(\mathrm{CH}_{2}\right)$, $23.8\left(\mathrm{CH}_{2}\right), 23.1\left(\mathrm{CH}_{2}\right), 18.4\left(\mathrm{CH}_{2}\right)$.

\section{(Z)-9-Hydroxynon-6-enoic acid (18)}

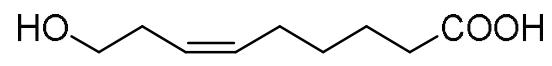

A solution of 9-hydroxynon-6-ynoic acid (17, $0.31 \mathrm{~g}, 1.82 \mathrm{mmol}, 1$ equiv.) in pyridine (50 mL) was degassed with $\mathrm{N}_{2}$ for 5 min. Lindlar catalyst (5\% palladium on $\mathrm{CaCO}_{3}$, poisoned with lead, $194 \mathrm{mg}, 0.09 \mathrm{mmol}, 5 \mathrm{~mol} \%$ ) was added and the mixture was vigorously stirred under an $\mathrm{H}_{2}$ atmosphere for $18 \mathrm{~h}$ (Johnson et al. 1982). The solution was filtered and concentrated under reduced pressure. The residue was dissolved in ethyl acetate and washed with $1 \mathrm{M}$ aq. $\mathrm{HCl}$. The aqueous layer was extracted with ethyl acetate. The combined organic layers were washed with sat. aq. $\mathrm{NaCl}$, dried with $\mathrm{MgSO}_{4}$, filtered and concentrated under reduced pressure to yield hydroxyacid 18: colorless liquid (0.31 g, $1.82 \mathrm{mmol}$, quant.).

$R_{\mathrm{f}}=0.24\left(\mathrm{CH}_{2} \mathrm{Cl}_{2} /\right.$ methanol 15:1);

$\mathrm{UV} / \mathrm{Vis}\left(\mathrm{CH}_{2} \mathrm{Cl}_{2}\right) \lambda_{\max }(\log \varepsilon) 227$ (2.22);

IR (neat) $v_{\max } 3600-2400$ (br), $3009(\mathrm{w}), 2934$ (m), 2864 (w), 1705 (s), 1407 (m), 1230 (m), $1104(\mathrm{w}), 1045(\mathrm{~s}), 871(\mathrm{w}), 721(\mathrm{w}), 599(\mathrm{w}) \mathrm{cm}^{-1}$;

${ }^{1} \mathrm{H} \mathrm{NMR}\left(\mathrm{CDCl}_{3}, 600 \mathrm{MHz}\right) \delta 5.54(1 \mathrm{H}, \mathrm{dtt}, J=10.7,7.4,1.6 \mathrm{~Hz},=\mathrm{CH}), 5.40(1 \mathrm{H}, \mathrm{dtt}, J=$ 10.7, 7.4, $1.5 \mathrm{~Hz},=\mathrm{CH}), 3.65\left(2 \mathrm{H}, \mathrm{t}, J=6.5 \mathrm{~Hz}, \mathrm{CH}_{2}\right), 2.34\left(2 \mathrm{H}\right.$, br q, $\left.J=6.3 \mathrm{~Hz}, \mathrm{CH}_{2}\right), 2.27$ $\left(2 \mathrm{H}\right.$, br q, $\left.J=6.5 \mathrm{~Hz}, \mathrm{CH}_{2}\right), 2.10\left(2 \mathrm{H}\right.$, br q, $\left.J=7.4 \mathrm{~Hz}, \mathrm{CH}_{2}\right), 1.65\left(2 \mathrm{H}\right.$, quint, $\left.J=7.6 \mathrm{~Hz}, \mathrm{CH}_{2}\right)$, $1.43\left(2 \mathrm{H}\right.$, quint, $J=7.6 \mathrm{~Hz}, \mathrm{CH}_{2}$ );

${ }^{13} \mathrm{C} \mathrm{NMR}\left(\mathrm{CDCl}_{3}, 150 \mathrm{MHz}\right) \delta 179.3(\mathrm{C}), 132.5(\mathrm{CH}), 125.6(\mathrm{CH}), 62.2\left(\mathrm{CH}_{2}\right), 33.8\left(\mathrm{CH}_{2}\right)$, $30.7\left(\mathrm{CH}_{2}\right), 28.9\left(\mathrm{CH}_{2}\right), 26.9\left(\mathrm{CH}_{2}\right), 24.2\left(\mathrm{CH}_{2}\right)$. 
Methyl (Z)-9-hydroxynon-6-enoate (23)

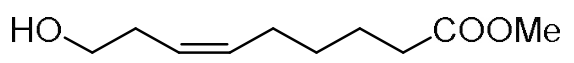

To a solution of (Z)-9-Hydroxynon-6-enoic acid (18, $191 \mathrm{mg}, 1.11 \mathrm{mmol}, 1$ equiv.) in acetonitrile $(5 \mathrm{~mL})$ were added 1,8-diazabicyclo[5.4.0]undec-7-ene (DBU, $0.18 \mathrm{~mL}$, 1.22 mmol, 1.1 equiv.) and methyl iodide (0.08 mL, 1.33 mmol, 1.2 equiv.) (Rao 1980). After stirring at room temperature for $2 \mathrm{~h}$, the reaction mixture was diluted with ethyl acetate and subsequently washed with $1 \mathrm{M}$ aq. $\mathrm{HCl}, 1 \mathrm{M}$ aq. $\mathrm{NaOH}$ and sat. aq. $\mathrm{NaCl}$. The organic layer was dried with $\mathrm{MgSO}_{4}$, filtered and concentrated under reduced pressure, yielding methyl ester 23: colorless liquid (120 mg, $0.64 \mathrm{mmol}, 58 \%$ ).

$R_{\mathrm{f}}=0.17$ (pentane/diethyl ether $\left.1: 1\right)$;

IR (neat) $v_{\max } 3404$ (br), 3008 (w), 2943 (m), 2863 (m), 1734 (s), 1438 (m), 1361 (w), 1202 (s), $1172(\mathrm{~s}), 1106(\mathrm{w}), 1048(\mathrm{~s}), 873(\mathrm{w}), 721(\mathrm{~m}), 586(\mathrm{w}) \mathrm{cm}^{-1}$;

${ }^{1} \mathrm{H} \mathrm{NMR}\left(\mathrm{CDCl}_{3}, 300 \mathrm{MHz}\right) \delta 5.59-5.50(1 \mathrm{H}, \mathrm{m},=\mathrm{CH}), 5.44-5.34(1 \mathrm{H}, \mathrm{m},=\mathrm{CH}), 3.67(3 \mathrm{H}, \mathrm{s}$, $\left.\mathrm{CH}_{3}\right), 3.65\left(2 \mathrm{H}, \mathrm{t}, J=6.5 \mathrm{~Hz}, \mathrm{CH}_{2}\right), 2.37-2.29\left(4 \mathrm{H}, \mathrm{m}, 2 \mathrm{CH}_{2}\right), 2.13-2.03\left(2 \mathrm{H}, \mathrm{m}, \mathrm{CH}_{2}\right), 1.70-$ $1.58\left(3 \mathrm{H}, \mathrm{m}, \mathrm{CH}_{2}, \mathrm{OH}\right), 1.45-1.34\left(2 \mathrm{H}, \mathrm{m}, \mathrm{CH}_{2}\right)$;

${ }^{13} \mathrm{C} \mathrm{NMR}\left(\mathrm{CDCl}_{3}, 75 \mathrm{MHz}\right) \delta 174.2(\mathrm{C}), 132.6(\mathrm{CH}), 125.6(\mathrm{CH}), 62.3\left(\mathrm{CH}_{2}\right), 51.5\left(\mathrm{CH}_{3}\right), 33.9$ $\left(\mathrm{CH}_{2}\right), 30.8\left(\mathrm{CH}_{2}\right), 29.1\left(\mathrm{CH}_{2}\right), 26.9\left(\mathrm{CH}_{2}\right), 24.5\left(\mathrm{CH}_{2}\right)$;

EIMS m/z 168 (8), 156 (43), 136 (22), 124 (93), 109 (15), 108 (15), 96 (76), 94 (100), 87 (38), 81 (72), 79 (98), 74 (88), 67 (76), 59 (50), 55 (78), 43 (32), 41 (58), 39 (33);

$I(\mathrm{HP} 5-\mathrm{MS})=1481$.

\section{(Z)-9-[(tert-Butyldimethylsilyl)oxy]non-6-enoic acid (24)}

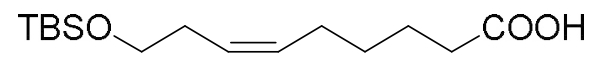

Imidazole (76 mg, $1.11 \mathrm{mmol}, 2.4$ equiv.) was dissolved in a solution of ( $Z$ )-9-Hydroxynon-6enoic acid (18, $80 \mathrm{mg}, 0.465 \mathrm{mmol}, 1$ equiv.) in DMF (3 mL) (Aguilar et al. 2014). tertButyldimethylsilyl chloride (91 mg, $0.60 \mathrm{mmol}, 1.3$ equiv.) was added and the reaction mixture was allowed to stand for $20 \mathrm{~h}$ at room temperature. The solvent was removed under reduced pressure and the residue was partitioned between ethyl acetate and water. The aqueous layer was extracted with ethyl acetate and the combined organic layers were washed with sat. aq. $\mathrm{NaCl}$, dried with $\mathrm{MgSO}_{4}$ and concentrated under reduced pressure. The residue was purified by column chromatography on silica (pentane/diethyl ether 4:1) to yield acid 24: colorless liquid (87 mg, $0.30 \mathrm{mmol}, 65 \%)$.

$R_{\mathrm{f}}=0.47$ (pentane/diethyl ether 2:1); 
IR (neat) $v_{\max }$ 3400-2500 (br), $3011(\mathrm{w}), 2931(\mathrm{~m}), 2858(\mathrm{~m}), 1709(\mathrm{~s}), 1466(\mathrm{w}), 1413(\mathrm{w})$, 1252 (m), 1094 (s), 931 (m), 833 (s), 774 (s), 732 (w), 664 (w) $\mathrm{cm}^{-1}$;

${ }^{1} \mathrm{H}$ NMR $\left(\mathrm{CDCl}_{3}, 300 \mathrm{MHz}\right) \delta 5.48-5.34(2 \mathrm{H}, \mathrm{m}, 2=\mathrm{CH}), 3.60\left(2 \mathrm{H}, \mathrm{t}, J=7.0 \mathrm{~Hz}, \mathrm{CH}_{2}\right), 2.36$ $\left(2 \mathrm{H}, \mathrm{t}, J=7.5 \mathrm{~Hz}, \mathrm{CH}_{2}\right), 2.30-2.23\left(2 \mathrm{H}, \mathrm{m}, \mathrm{CH}_{2}\right), 2.11-2.04\left(2 \mathrm{H}, \mathrm{m}, \mathrm{CH}_{2}\right), 1.70-1.60(2 \mathrm{H}, \mathrm{m}$, $\left.\mathrm{CH}_{2}\right), 1.46-1.36\left(2 \mathrm{H}, \mathrm{m}, \mathrm{CH}_{2}\right), 0.89\left(9 \mathrm{H}, \mathrm{s}, 3 \mathrm{CH}_{3}\right), 0.05\left(6 \mathrm{H}, \mathrm{s}, 2 \mathrm{CH}_{3}\right)$;

${ }^{13} \mathrm{C} \mathrm{NMR}\left(\mathrm{CDCl}_{3}, 75 \mathrm{MHz}\right) \delta 179.0(\mathrm{C}), 131.0(\mathrm{CH}), 126.2(\mathrm{CH}), 63.0\left(\mathrm{CH}_{2}\right), 33.8\left(\mathrm{CH}_{2}\right), 31.1$ $\left(\mathrm{CH}_{2}\right), 29.0\left(\mathrm{CH}_{2}\right), 26.9\left(\mathrm{CH}_{2}\right), 26.0\left(3 \mathrm{CH}_{3}\right), 24.3\left(\mathrm{CH}_{2}\right), 18.4(\mathrm{C}),-5.3\left(2 \mathrm{CH}_{3}\right)$.

\section{(Z)-Hexadec-11-enoic acid (26)}

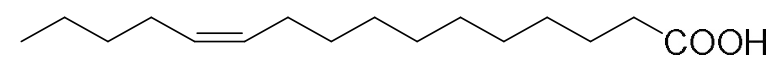

11-Bromoundecanoic acid (25, $1.02 \mathrm{~g}, 3.85 \mathrm{mmol}, 1$ equiv.) and triphenylphosphine $(1.01 \mathrm{~g}$, 3.85 mmol, 1 equiv.) were melted under an $\mathrm{N}_{2}$ atmosphere and stirred at $100-110^{\circ} \mathrm{C}$ for $19 \mathrm{~h}$. After cooling to room temperature, THF $(15 \mathrm{~mL})$ and sodium bis(trimethylsilyl)amide (NaHMDS, $1 \mathrm{M}$ solution in THF, $9.1 \mathrm{~mL}, 9.1 \mathrm{mmol}, 2.4$ equiv.) were added and the mixture was stirred until the glassy Wittig salt had dissolved $(17 \mathrm{~h})$, forming a turbid orange solution. The reaction mixture was cooled to $-90^{\circ} \mathrm{C}$ and pentanal $(0.50 \mathrm{~mL}, 4.70 \mathrm{mmol}, 1.2$ equiv. $)$ was added dropwise (Wube et al. 2011). The mixture was allowed to warm to room temperature over $24 \mathrm{~h}$, poured into $1 \mathrm{M}$ aq $\mathrm{HCl}$ and extracted three times with diethyl ether. The combined organic layers were dried with $\mathrm{MgSO}_{4}$, filtered and concentrated under reduced pressure. The residue was purified by column chromatography on silica (pentane/diethyl ether 4:1) to yield acid 26: colorless oil (0.53 g, $2.08 \mathrm{mmol}, 54 \%)$.

$R_{\mathrm{f}}=0.47$ (pentane/diethyl ether $\left.2: 1\right)$

IR (neat) $v_{\max }$ 3300-2400 (br), $3005(\mathrm{w}), 2923(\mathrm{~s}), 2854(\mathrm{~m}), 1708$ (s), $1459(\mathrm{~m}), 1414(\mathrm{~m})$, $1286(\mathrm{~m}), 1236(\mathrm{~m}), 1098(\mathrm{w}), 934(\mathrm{~m}), 720(\mathrm{~m}) \mathrm{cm}^{-1}$;

${ }^{1} \mathrm{H} \mathrm{NMR}\left(\mathrm{CDCl}_{3}, 300 \mathrm{MHz}\right) \delta 11.42(1 \mathrm{H}, \mathrm{br} \mathrm{s}, \mathrm{OH}), 5.40-5.29(2 \mathrm{H}, \mathrm{m}, 2=\mathrm{CH}), 2.34(2 \mathrm{H}, \mathrm{t}, J$ $\left.=7.5 \mathrm{~Hz}, \mathrm{CH}_{2}\right), 2.07-1.95\left(4 \mathrm{H}, \mathrm{m}, 2 \mathrm{CH}_{2}\right), 1.68-1.58\left(2 \mathrm{H}, \mathrm{m}, \mathrm{CH}_{2}\right), 1.39-1.25\left(16 \mathrm{H}, \mathrm{m}, 8 \mathrm{CH}_{2}\right)$, $0.92-0.87\left(3 \mathrm{H}, \mathrm{m}, \mathrm{CH}_{3}\right)$;

${ }^{13} \mathrm{C} \mathrm{NMR}\left(\mathrm{CDCl}_{3}, 75 \mathrm{MHz}\right) \delta 180.5(\mathrm{C}), 129.9(\mathrm{CH}), 129.8(\mathrm{CH}), 34.1\left(\mathrm{CH}_{2}\right), 32.0\left(\mathrm{CH}_{2}\right), 29.7$ $\left(\mathrm{CH}_{2}\right), 29.5\left(\mathrm{CH}_{2}\right), 29.4\left(\mathrm{CH}_{2}\right), 29.25\left(\mathrm{CH}_{2}\right), 29.22\left(\mathrm{CH}_{2}\right), 29.0\left(\mathrm{CH}_{2}\right), 27.2\left(\mathrm{CH}_{2}\right), 26.9\left(\mathrm{CH}_{2}\right)$, $24.7\left(\mathrm{CH}_{2}\right), 22.3\left(\mathrm{CH}_{2}\right), 14.0\left(\mathrm{CH}_{3}\right)$.

\section{General esterification procedure}

The respective alcohol $(\mathbf{2 0}, \mathbf{2 3})$ and carboxylic acid $(\mathbf{2 2}, \mathbf{2 4}, \mathbf{2 6})$ were dissolved in $\mathrm{CH}_{2} \mathrm{Cl}_{2}$ $(2 \mathrm{~mL})$. Triethylamine (1.5 equiv.), 4-(dimethylamino)pyridine (DMAP, 0.3 equiv.) and 1ethyl-3-(3-dimethylaminopropyl)carbodiimide hydrochloride ( $\mathrm{EDC} \cdot \mathrm{HCl}, 1.5$ equiv.) were 
added and the reaction mixture was allowed to stand at room temperature for the indicated amount of time.

Workup A: The reaction mixture was washed with $1 \mathrm{M}$ aq. $\mathrm{HCl}$. The aqueous layer was extracted with diethyl ether and the combined organic layers were dried with $\mathrm{MgSO}_{4}$, filtered and concentrated under reduced pressure. The residue was purified by column chromatography on silica (pentane/diethyl ether 10:1) to yield the respective ester as a colorless liquid.

Workup B: The reaction mixture was directly subjected to column chromatography on silica (pentane/diethyl ether 10:1) to yield the respective ester as a colorless liquid.

Methyl 9-[((Z)-hexadec-11-enoyl)oxy]nonanoate (Me-31)

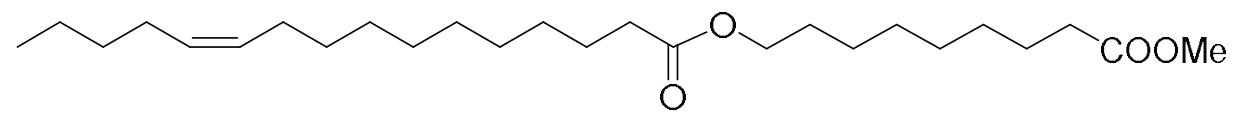

(Z)-Hexadec-11-enoic acid (26, $36 \mathrm{mg}, 0.14 \mathrm{mmol}, 1$ equiv.) and methyl 9-hydroxynonanoate (20, $29 \mathrm{mg}, 0.15 \mathrm{mmol}, 1.1$ equiv.) yielded ester Me-31 (56 mg, $0.13 \mathrm{mmol}, 94 \%)$ after $18 \mathrm{~h}$ reaction time and workup A.

$R_{\mathrm{f}}=0.17$ (pentane/diethyl ether 10:1);

IR (neat) $v_{\max } 3002(\mathrm{w}), 2925(\mathrm{~s}), 2855(\mathrm{~m}), 1737(\mathrm{~s}), 1460(\mathrm{~m}), 1440(\mathrm{~m}), 1357(\mathrm{w}), 1244(\mathrm{~m})$, $1169(\mathrm{~s}), 1106(\mathrm{~m}), 1018(\mathrm{w}), 722(\mathrm{~m}) \mathrm{cm}^{-1}$;

${ }^{1} \mathrm{H}$ NMR $\left(\mathrm{CDCl}_{3}, 300 \mathrm{MHz}\right) \delta 5.40-5.29(2 \mathrm{H}, \mathrm{m}, 2=\mathrm{CH}), 4.05\left(2 \mathrm{H}, \mathrm{t}, J=6.7 \mathrm{~Hz}, \mathrm{CH}_{2}\right), 3.67$ $\left(3 \mathrm{H}, \mathrm{s}, \mathrm{CH}_{3}\right), 2.30\left(2 \mathrm{H}, \mathrm{t}, J=7.5 \mathrm{~Hz}, \mathrm{CH}_{2}\right), 2.29\left(2 \mathrm{H}, \mathrm{t}, J=7.5 \mathrm{~Hz}, \mathrm{CH}_{2}\right), 2.06-1.95(4 \mathrm{H}, \mathrm{m}, 2$ $\left.\mathrm{CH}_{2}\right), 1.67-1.56\left(6 \mathrm{H}, \mathrm{m}, 3 \mathrm{CH}_{2}\right), 1.39-1.24\left(24 \mathrm{H}, \mathrm{m}, 12 \mathrm{CH}_{2}\right), 0.93-0.86\left(3 \mathrm{H}, \mathrm{m}, \mathrm{CH}_{3}\right)$;

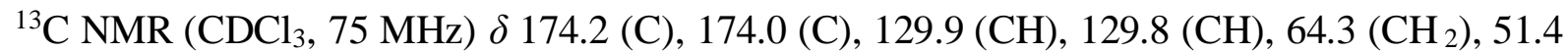
$\left(\mathrm{CH}_{3}\right), 34.4\left(\mathrm{CH}_{2}\right), 34.1\left(\mathrm{CH}_{2}\right), 32.0\left(\mathrm{CH}_{2}\right), 29.7\left(\mathrm{CH}_{2}\right), 29.5\left(\mathrm{CH}_{2}\right), 29.4\left(\mathrm{CH}_{2}\right), 29.3\left(2 \mathrm{CH}_{2}\right)$, $29.2\left(\mathrm{CH}_{2}\right), 29.1\left(\mathrm{CH}_{2}\right), 29.0\left(2 \mathrm{CH}_{2}\right), 28.6\left(\mathrm{CH}_{2}\right), 27.2\left(\mathrm{CH}_{2}\right), 26.9\left(\mathrm{CH}_{2}\right), 25.9\left(\mathrm{CH}_{2}\right), 25.0$ $\left(\mathrm{CH}_{2}\right), 24.9\left(\mathrm{CH}_{2}\right), 22.3\left(\mathrm{CH}_{2}\right), 14.0\left(\mathrm{CH}_{3}\right)$;

EIMS m/z 424 (7, [M] $\left.]^{+}\right), 393$ (23), 392 (21), 375 (2), 363 (3), 349 (4), 335 (3), 321 (2), 307 (2), 236 (46), 234 (27), 193 (6), 189 (8), 171 (24), 152 (11), 139 (63), 123 (15), 121 (18), 111 (20), 97 (61), 83 (35), 81 (34), 74 (27), 69 (73), 67 (29), 55 (100), 43 (27), 41 (36);

$I(\mathrm{HP} 5-\mathrm{MS})=3002$.

Methyl (Z)-9-[((Z)-hexadec-11-enoyl)oxy]non-6-enoate (Me-32)<smiles>CCCCC=CCCCCCCCCCC(=O)OCCC=CCCCCC(=O)OC</smiles>

(Z)-Hexadec-11-enoic acid (26, $20 \mathrm{mg}, 0.081 \mathrm{mmol}, 1$ equiv.) and methyl ( $Z$ )-9-hydroxynon6-enoate (23, $15 \mathrm{mg}, 0.081 \mathrm{mmol}, 1$ equiv.) yielded ester Me-32 (25 mg, $0.060 \mathrm{mmol}, 74 \%$ ) after $3.5 \mathrm{~d}$ reaction time and workup $\mathrm{B}$. 
$R_{\mathrm{f}}=0.27$ (pentane/diethyl ether 10:1);

IR (neat) $v_{\max } 3007(\mathrm{w}), 2924$ (s), 2855 (m), 1737 (s), 1459 (m), 1440 (m), 1354 (w), 1168 (s), $1111(\mathrm{w}), 1058(\mathrm{w}), 1007(\mathrm{~m}), 721(\mathrm{~m}) \mathrm{cm}^{-1}$;

${ }^{1} \mathrm{H} \mathrm{NMR}\left(\mathrm{CDCl}_{3}, 300 \mathrm{MHz}\right) \delta 5.53-5.44(1 \mathrm{H}, \mathrm{m},=\mathrm{CH}), 5.41-5.29(3 \mathrm{H}, \mathrm{m}, 3=\mathrm{CH}), 4.06(2 \mathrm{H}$, $\left.\mathrm{t}, J=7.0 \mathrm{~Hz}, \mathrm{CH}_{2}\right), 3.67\left(3 \mathrm{H}, \mathrm{s}, \mathrm{CH}_{3}\right), 2.41-2.33\left(2 \mathrm{H}, \mathrm{m}, \mathrm{CH}_{2}\right), 2.32\left(2 \mathrm{H}, \mathrm{t}, J=7.5 \mathrm{~Hz}, \mathrm{CH}_{2}\right)$, $2.29\left(2 \mathrm{H}, \mathrm{t}, J=7.6 \mathrm{~Hz}, \mathrm{CH}_{2}\right), 2.11-1.95\left(6 \mathrm{H}, \mathrm{m}, 3 \mathrm{CH}_{2}\right), 1.69-1.56\left(4 \mathrm{H}, \mathrm{m}, 2 \mathrm{CH}_{2}\right), 1.44-1.23$ $\left(18 \mathrm{H}, \mathrm{m}, 9 \mathrm{CH}_{2}\right), 0.93-0.85\left(3 \mathrm{H}, \mathrm{m}, \mathrm{CH}_{3}\right)$;

${ }^{13} \mathrm{C} \mathrm{NMR}\left(\mathrm{CDCl}_{3}, 75 \mathrm{MHz}\right) \delta 174.1(\mathrm{C}), 173.9(\mathrm{C}), 132.1(\mathrm{CH}), 129.9(\mathrm{CH}), 129.8(\mathrm{CH}), 124.9$ $(\mathrm{CH}), 63.6\left(\mathrm{CH}_{2}\right), 51.5\left(\mathrm{CH}_{3}\right), 34.3\left(\mathrm{CH}_{2}\right), 33.9\left(\mathrm{CH}_{2}\right), 31.9\left(\mathrm{CH}_{2}\right), 29.7\left(\mathrm{CH}_{2}\right), 29.5\left(\mathrm{CH}_{2}\right)$, $29.4\left(\mathrm{CH}_{2}\right), 29.3\left(2 \mathrm{CH}_{2}\right), 29.1\left(\mathrm{CH}_{2}\right), 29.0\left(\mathrm{CH}_{2}\right), 27.2\left(\mathrm{CH}_{2}\right), 26.90\left(2 \mathrm{CH}_{2}\right), 26.87\left(\mathrm{CH}_{2}\right), 25.0$ $\left(\mathrm{CH}_{2}\right), 24.5\left(\mathrm{CH}_{2}\right), 22.3\left(\mathrm{CH}_{2}\right), 14.0\left(\mathrm{CH}_{3}\right)$;

EIMS m/z $422\left(1,[\mathrm{M}]^{+}\right), 391$ (4), 237 (6), 168 (50), 137 (57), 119 (12), 109 (18), 94 (100), 81 (16), 79 (19), 69 (20), 67 (28), 55 (44), 43 (12), 41 (19);

$I(\mathrm{HP} 5-\mathrm{MS})=2982$.

Methyl 9-\{[9-((tert-butyldimethylsilyl)oxy)nonanoyl]oxy\}nonanoate (27)<smiles>CC(=O)CCCCCCCCOC(=O)CCCCCCCCCO[AsH3-]</smiles>

9-[(tert-Butyldimethylsilyl)oxy]nonanoic acid (22, $35 \mathrm{mg}, 0.12 \mathrm{mmol}, 1$ equiv.) and methyl 9-hydroxynonanoate (20, $25 \mathrm{mg}, 0.13 \mathrm{mmol}, 1.1$ equiv.) yielded ester 27 (44 mg, $0.10 \mathrm{mmol}$, $80 \%$ ) after $2 \mathrm{~d}$ reaction time and workup B.

$R_{\mathrm{f}}=0.24$ (pentane/diethyl ether 8:1);

IR (neat) $v_{\max } 2929(\mathrm{~m}), 2857(\mathrm{~m}), 1737(\mathrm{~s}), 1464(\mathrm{~m}), 1359(\mathrm{w}), 1250(\mathrm{~m}), 1168$ (s), 1097 (s), $1008(\mathrm{w}), 836(\mathrm{~s}), 775(\mathrm{~s}), 722(\mathrm{w}), 662(\mathrm{w}) \mathrm{cm}^{-1}$;

${ }^{1} \mathrm{H} \mathrm{NMR}\left(\mathrm{CDCl}_{3}, 300 \mathrm{MHz}\right) \delta 4.05\left(2 \mathrm{H}, \mathrm{t}, J=6.7 \mathrm{~Hz}, \mathrm{CH}_{2}\right), 3.67\left(3 \mathrm{H}, \mathrm{s}, \mathrm{CH}_{3}\right), 3.59(2 \mathrm{H}, \mathrm{t}, J$ $\left.=6.6 \mathrm{~Hz}, \mathrm{CH}_{2}\right), 2.30\left(2 \mathrm{H}, \mathrm{t}, J=7.5 \mathrm{~Hz}, \mathrm{CH}_{2}\right), 2.29\left(2 \mathrm{H}, \mathrm{t}, J=7.5 \mathrm{~Hz}, \mathrm{CH}_{2}\right), 1.68-1.56(6 \mathrm{H}, \mathrm{m}$, $\left.3 \mathrm{CH}_{2}\right), 1.53-1.45\left(2 \mathrm{H}, \mathrm{m}, \mathrm{CH}_{2}\right), 1.37-1.25\left(16 \mathrm{H}, \mathrm{m}, 8 \mathrm{CH}_{2}\right), 0.89\left(9 \mathrm{H}, \mathrm{s}, 3 \mathrm{CH}_{3}\right), 0.04(6 \mathrm{H}, \mathrm{s}$, $2 \mathrm{CH}_{3}$;

${ }^{13} \mathrm{C} \mathrm{NMR}\left(\mathrm{CDCl}_{3}, 75 \mathrm{MHz}\right) \delta 174.2(\mathrm{C}), 174.0(\mathrm{C}), 64.3\left(\mathrm{CH}_{2}\right), 63.3\left(\mathrm{CH}_{2}\right), 51.4\left(\mathrm{CH}_{3}\right), 34.3$ $\left(\mathrm{CH}_{2}\right), 34.0\left(\mathrm{CH}_{2}\right), 32.8\left(\mathrm{CH}_{2}\right), 29.2\left(2 \mathrm{CH}_{2}\right), 29.1\left(2 \mathrm{CH}_{2}\right), 29.0\left(2 \mathrm{CH}_{2}\right), 28.6\left(\mathrm{CH}_{2}\right), 26.0(3$ $\left.\mathrm{CH}_{3}\right), 25.8\left(\mathrm{CH}_{2}\right), 25.7\left(\mathrm{CH}_{2}\right), 25.0\left(\mathrm{CH}_{2}\right), 24.9\left(\mathrm{CH}_{2}\right), 18.4(\mathrm{C}),-5.3\left(2 \mathrm{CH}_{3}\right)$;

EIMS m/z 427 (2), 401 (15), 289 (2), 271 (5), 255 (5), 245 (3), 231 (11), 213 (100), 171 (7), 157 (3), 139 (21), 121 (6), 115 (5), 97 (12), 75 (24), 73 (12), 69 (19), 55 (22). 
Methyl (Z)-9-\{[9-((tert-butyldimethylsilyl)oxy)nonanoyl]oxy\}non-6-enoate (28)

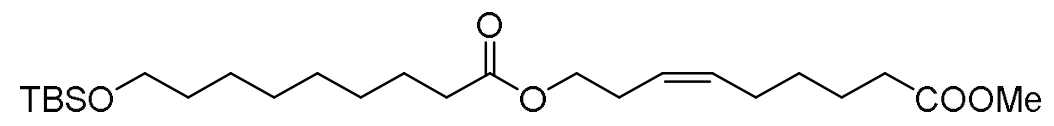

9-[(tert-Butyldimethylsilyl)oxy]nonanoic acid (22, $23 \mathrm{mg}, 0.081 \mathrm{mmol}, 1$ equiv.) and methyl (Z)-9-hydroxynon-6-enoate $(\mathbf{2 3}, 15 \mathrm{mg}, 0.081 \mathrm{mmol}, 1$ equiv.) yielded ester 28 (25 mg, $0.055 \mathrm{mmol}, 68 \%$ ) after $3.5 \mathrm{~d}$ reaction time and workup B.

$R_{\mathrm{f}}=0.20($ pentane/diethyl ether 10:1);

IR (neat) $v_{\max } 2930(\mathrm{~s}), 2857(\mathrm{~m}), 1736(\mathrm{~s}), 1462(\mathrm{~m}), 1356(\mathrm{w}), 1249(\mathrm{~m}), 1168(\mathrm{~s}), 1098(\mathrm{~s})$, 1057 (w), 1007 (w), 836 (s), $775(\mathrm{~m}), 723(\mathrm{~m}), 664(\mathrm{w}), 580(\mathrm{w}) \mathrm{cm}^{-1}$;

${ }^{1} \mathrm{H}$ NMR $\left(\mathrm{CDCl}_{3}, 300 \mathrm{MHz}\right) \delta$ 5.53-5.44 $(1 \mathrm{H}, \mathrm{m},=\mathrm{CH}), 5.41-5.30(1 \mathrm{H}, \mathrm{m},=\mathrm{CH}), 4.06(2 \mathrm{H}, \mathrm{t}$, $\left.J=7.0 \mathrm{~Hz}, \mathrm{CH}_{2}\right), 3.67\left(3 \mathrm{H}, \mathrm{s}, \mathrm{CH}_{3}\right), 3.59\left(2 \mathrm{H}, \mathrm{t}, J=6.6 \mathrm{~Hz}, \mathrm{CH}_{2}\right), 2.41-2.26\left(6 \mathrm{H}, \mathrm{m}, 3 \mathrm{CH}_{2}\right)$, 2.11-2.03 (2H, m, $\left.\mathrm{CH}_{2}\right), 1.70-1.57\left(4 \mathrm{H}, \mathrm{m}, 2 \mathrm{CH}_{2}\right)$ 1.54-1.46 (2H, m, $\left.\mathrm{CH}_{2}\right), 1.44-1.36(2 \mathrm{H}, \mathrm{m}$, $\left.\mathrm{CH}_{2}\right), 1.34-1.26\left(8 \mathrm{H}, \mathrm{m}, 4 \mathrm{CH}_{2}\right), 0.89\left(9 \mathrm{H}, \mathrm{s}, 3 \mathrm{CH}_{3}\right), 0.04\left(6 \mathrm{H}, \mathrm{s}, 2 \mathrm{CH}_{3}\right)$;

${ }^{13} \mathrm{C} \mathrm{NMR}\left(\mathrm{CDCl}_{3}, 75 \mathrm{MHz}\right) \delta 174.0(\mathrm{C}), 173.9(\mathrm{C}), 132.1(\mathrm{CH}), 124.9(\mathrm{CH}), 63.6\left(\mathrm{CH}_{2}\right), 63.3$ $\left(\mathrm{CH}_{2}\right), 51.5\left(\mathrm{CH}_{3}\right), 34.3\left(\mathrm{CH}_{2}\right), 33.9\left(\mathrm{CH}_{2}\right), 32.8\left(\mathrm{CH}_{2}\right), 29.2\left(2 \mathrm{CH}_{2}\right), 29.1\left(\mathrm{CH}_{2}\right), 29.0\left(\mathrm{CH}_{2}\right)$, $26.91\left(\mathrm{CH}_{2}\right), 26.87\left(\mathrm{CH}_{2}\right), 26.0\left(3 \mathrm{CH}_{3}\right), 25.7\left(\mathrm{CH}_{2}\right), 24.9\left(\mathrm{CH}_{2}\right), 24.5\left(\mathrm{CH}_{2}\right), 18.4(\mathrm{C}),-5.3(2$ $\left.\mathrm{CH}_{3}\right)$;

EIMS m/z 425 (4), 399 (2), 289 (7), 271 (7), 255 (5), 231 (37), 213 (100), 169 (46), 137 (95), 119 (22), 109 (30), 95 (67), 79 (19), 75 (44), 73 (23), 69 (20), 67 (33), 59 (12), 55 (31), 43 (11), $41(13)$.

Methyl 9-\{[(Z)-9-((tert-butyldimethylsilyl)oxy)non-6-enoyl $]$ oxy $\}$ nonanoate (29)<smiles>CC(=O)CCCCCCCCOC(=O)CCCC/C=C/CCO[R5](F)(F)F</smiles>

(Z)-9-[(tert-Butyldimethylsilyl)oxy]non-6-enoic acid (24, $17 \mathrm{mg}, 0.058 \mathrm{mmol}, 0.7$ equiv.) and methyl 9-hydroxynonanoate (20, $15 \mathrm{mg}, 0.081 \mathrm{mmol}, 1$ equiv.) yielded ester 29 (16 mg, $0.036 \mathrm{mmol}, 61 \%$ ) after $3.5 \mathrm{~d}$ reaction time and workup B.

$R_{\mathrm{f}}=0.20($ pentane/diethyl ether 10:1);

IR (neat) $v_{\max } 2931(\mathrm{~s}), 2858(\mathrm{~m}), 1737(\mathrm{~s}), 1462(\mathrm{~m}), 1359(\mathrm{w}), 1252(\mathrm{~m}), 1173(\mathrm{~m}), 1100(\mathrm{~m})$, $1053(\mathrm{w}), 838(\mathrm{~m}), 778(\mathrm{~m}) \mathrm{cm}^{-1}$;

${ }^{1} \mathrm{H} \mathrm{NMR}\left(\mathrm{CDCl}_{3}, 300 \mathrm{MHz}\right) \delta 5.49-5.33(2 \mathrm{H}, \mathrm{m}, 2=\mathrm{CH}), 4.05\left(2 \mathrm{H}, \mathrm{t}, J=6.7 \mathrm{~Hz}, \mathrm{CH}_{2}\right), 3.67$ $\left(3 \mathrm{H}, \mathrm{s}, \mathrm{CH}_{3}\right), 3.60\left(2 \mathrm{H}, \mathrm{t}, J=7.0 \mathrm{~Hz}, \mathrm{CH}_{2}\right), 2.303\left(2 \mathrm{H}, \mathrm{t}, J=7.6 \mathrm{~Hz}, \mathrm{CH}_{2}\right), 2.297(2 \mathrm{H}, \mathrm{t}, J=$ 
$\left.7.4 \mathrm{~Hz}, \mathrm{CH}_{2}\right), 2.29-2.23\left(2 \mathrm{H}, \mathrm{m}, \mathrm{CH}_{2}\right), 2.06\left(2 \mathrm{H}\right.$, br q, $\left.J=7.1 \mathrm{~Hz}, \mathrm{CH}_{2}\right), 1.69-1.56(6 \mathrm{H}, \mathrm{m}, 3$ $\left.\mathrm{CH}_{2}\right), 1.43-1.26\left(10 \mathrm{H}, \mathrm{m}, 5 \mathrm{CH}_{2}\right), 0.89\left(9 \mathrm{H}, \mathrm{s}, 3 \mathrm{CH}_{3}\right), 0.05\left(6 \mathrm{H}, \mathrm{s}, 2 \mathrm{CH}_{3}\right)$;

${ }^{13} \mathrm{C} \mathrm{NMR}\left(\mathrm{CDCl}_{3}, 75 \mathrm{MHz}\right) \delta 174.3(\mathrm{C}), 173.8(\mathrm{C}), 131.1(\mathrm{CH}), 126.1(\mathrm{CH}), 64.4\left(\mathrm{CH}_{2}\right), 63.0$ $\left(\mathrm{CH}_{2}\right), 51.4\left(\mathrm{CH}_{3}\right), 34.3\left(\mathrm{CH}_{2}\right), 34.1\left(\mathrm{CH}_{2}\right), 31.1\left(\mathrm{CH}_{2}\right), 29.2\left(\mathrm{CH}_{2}\right), 29.1\left(\mathrm{CH}_{2}\right), 29.0\left(2 \mathrm{CH}_{2}\right)$, $28.6\left(\mathrm{CH}_{2}\right), 27.0\left(\mathrm{CH}_{2}\right), 26.0\left(3 \mathrm{CH}_{3}\right), 25.9\left(\mathrm{CH}_{2}\right), 24.9\left(\mathrm{CH}_{2}\right), 24.6\left(\mathrm{CH}_{2}\right), 18.4(\mathrm{C}),-5.3(2$ $\left.\mathrm{CH}_{3}\right)$;

EIMS m/z 425 (1), 399 (41), 293 (3), 253 (4), 245 (4), 229 (10), 211 (100), 199 (18), 171 (10), 155 (6), 139 (28), 137 (43), 129 (17), 119 (17), 109 (12), 97 (16 ), 95 (24), 93 (13), 89 (33), 75 (36), 73 (38), 71 (14), 69 (22), 67 (16), 59 (12), 55 (31), 43 (13), 41 (12).

Methyl (Z)-9-\{[(Z)-9-((tert-butyldimethylsilyl)oxy)non-6-enoyl]oxy\}non-6-enoate (30)

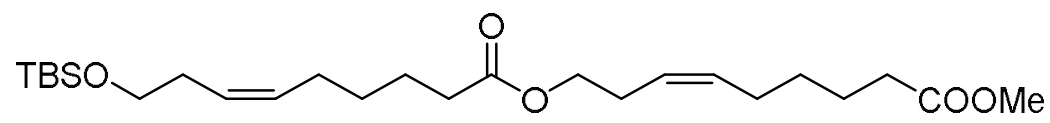

(Z)-9-[(tert-Butyldimethylsilyl)oxy]non-6-enoic acid (24, $23 \mathrm{mg}, 0.081 \mathrm{mmol}, 1$ equiv.) and methyl (Z)-9-hydroxynon-6-enoate (23, $15 \mathrm{mg}, 0.081 \mathrm{mmol}, 1$ equiv.) yielded ester $\mathbf{3 0}$ (22 $\mathrm{mg}$, $0.049 \mathrm{mmol}, 61 \%$ ) after $3.5 \mathrm{~d}$ reaction time and workup B.

$R_{\mathrm{f}}=0.20$ (pentane/diethyl ether 10:1);

IR (neat) $v_{\max } 3010(\mathrm{w}), 2932(\mathrm{~m}), 2858(\mathrm{~m}), 1736(\mathrm{~s}), 1463(\mathrm{~m}), 1356(\mathrm{w}), 1252(\mathrm{~m}), 1154$ (m), $1095(\mathrm{~s}), 1007(\mathrm{~m}), 931(\mathrm{w}), 835(\mathrm{~s}), 776(\mathrm{~s}), 727(\mathrm{~m}), 664(\mathrm{w}), 582(\mathrm{w}) \mathrm{cm}^{-1}$;

${ }^{1} \mathrm{H} \mathrm{NMR}\left(\mathrm{CDCl}_{3}, 300 \mathrm{MHz}\right) \delta 5.53-5.30(4 \mathrm{H}, \mathrm{m}, 4=\mathrm{CH}), 4.06\left(2 \mathrm{H}, \mathrm{t}, J=7.0 \mathrm{~Hz}, \mathrm{CH}_{2}\right), 3.67$ $\left(3 \mathrm{H}, \mathrm{s}, \mathrm{CH}_{3}\right), 3.60\left(2 \mathrm{H}, \mathrm{t}, J=7.0 \mathrm{~Hz}, \mathrm{CH}_{2}\right), 2.40-2.22\left(8 \mathrm{H}, \mathrm{m}, 4 \mathrm{CH}_{2}\right), 2.11-2.02\left(4 \mathrm{H}, \mathrm{m}, 2 \mathrm{CH}_{2}\right)$ 1.69-1.58 (4H, m, $\left.2 \mathrm{CH}_{2}\right), 1.44-1.32\left(4 \mathrm{H}, \mathrm{m}, 2 \mathrm{CH}_{2}\right) 0.89\left(9 \mathrm{H}, \mathrm{s}, 3 \mathrm{CH}_{3}\right), 0.05\left(6 \mathrm{H}, \mathrm{s}, 2 \mathrm{CH}_{3}\right)$;

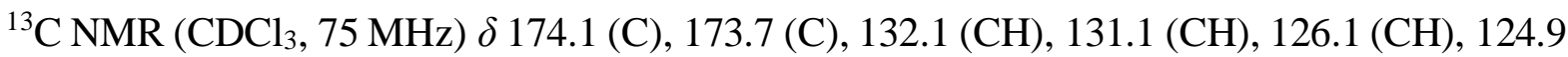
$(\mathrm{CH}), 63.7\left(\mathrm{CH}_{2}\right), 62.9\left(\mathrm{CH}_{2}\right), 51.5\left(\mathrm{CH}_{3}\right), 34.2\left(\mathrm{CH}_{2}\right), 33.9\left(\mathrm{CH}_{2}\right), 31.1\left(\mathrm{CH}_{2}\right), 29.1\left(\mathrm{CH}_{2}\right)$, $29.0\left(\mathrm{CH}_{2}\right), 27.0\left(\mathrm{CH}_{2}\right), 26.90\left(\mathrm{CH}_{2}\right), 26.86\left(\mathrm{CH}_{2}\right), 25.9\left(3 \mathrm{CH}_{3}\right), 24.6\left(\mathrm{CH}_{2}\right), 24.5\left(\mathrm{CH}_{2}\right), 18.4$ (C), $-5.3\left(2 \mathrm{CH}_{3}\right)$;

EIMS m/z 397 (2), 269 (4), 253 (3), 229 (20), 211 (51), 199 (8), 169 (43), 155 (5), 137 (100), 119 (25), 109 (30), 95 (64), 89 (31), 79 (16), 75 (31), 73 (35), 67 (33), 59 (11), 55 (21), 43 (9), $41(11)$.

\section{General TBS-deprotection procedure}

The respective TBS-protected alcohol (27-30) was dissolved in a 2:1:1 $\mathrm{AcOH} / \mathrm{H}_{2} \mathrm{O} / \mathrm{THF}$ mixture $(2-4 \mathrm{~mL})$. The reaction mixture was allowed to stand at room temperature for $18 \mathrm{~h}$ (Corey and Venkateswarlu 1972).

Workup A: The mixture was poured into sat. aq. $\mathrm{NaHCO}_{3}$. The aqueous layer was extracted two times with ethyl acetate and the combined organic layers were washed with sat. aq. $\mathrm{NaCl}$, 
dried with $\mathrm{MgSO}_{4}$ and concentrated in a high vacuum to yield the respective alcohol as a colorless liquid.

Workup B: Volatiles were directly removed in a high vacuum to yield the respective alcohol as a colorless liquid.

Methyl 9-[(9-hydroxynonanoyl)oxy]nonanoate (Me-35)<smiles>COC(=O)CCCCCCCCOC(=O)CCCCCCCCO</smiles>

Methyl 9-\{[9-((tert-butyldimethylsilyl)oxy)nonanoyl]oxy $\}$ nonanoate $(\mathbf{2 7}, 44 \mathrm{mg}, 0.10 \mathrm{mmol})$ yielded alcohol Me-35 (27 mg, $0.078 \mathrm{mmol}, 81 \%)$ after workup A.

$R_{\mathrm{f}}=0.15$ (pentane/diethyl ether $\left.1: 1\right)$

${ }^{1} \mathrm{H}$ NMR $\left(\mathrm{CDCl}_{3}, 300 \mathrm{MHz}\right) \delta 4.05\left(2 \mathrm{H}, \mathrm{t}, J=6.7 \mathrm{~Hz}, \mathrm{CH}_{2}\right), 3.67\left(3 \mathrm{H}, \mathrm{s}, \mathrm{CH}_{3}\right), 3.64(2 \mathrm{H}, \mathrm{t}, J$ $\left.=6.6 \mathrm{~Hz}, \mathrm{CH}_{2}\right), 2.30\left(2 \mathrm{H}, \mathrm{t}, J=7.5 \mathrm{~Hz}, \mathrm{CH}_{2}\right), 2.29\left(2 \mathrm{H}, \mathrm{t}, J=7.5 \mathrm{~Hz}, \mathrm{CH}_{2}\right), 1.70-1.51(9 \mathrm{H}, \mathrm{m}$, $\left.4 \mathrm{CH}_{2}, \mathrm{OH}\right), 1.39-1.25\left(16 \mathrm{H}, \mathrm{m}, 8 \mathrm{CH}_{2}\right)$;

${ }^{13} \mathrm{C} \mathrm{NMR}\left(\mathrm{CDCl}_{3}, 75 \mathrm{MHz}\right) \delta 174.3(\mathrm{C}), 173.9(\mathrm{C}), 64.3\left(\mathrm{CH}_{2}\right), 62.9\left(\mathrm{CH}_{2}\right), 51.4\left(\mathrm{CH}_{3}\right), 34.3$ $\left(\mathrm{CH}_{2}\right), 34.0\left(\mathrm{CH}_{2}\right), 32.7\left(\mathrm{CH}_{2}\right), 29.2\left(2 \mathrm{CH}_{2}\right), 29.1\left(\mathrm{CH}_{2}\right), 29.0\left(3 \mathrm{CH}_{2}\right), 28.6\left(\mathrm{CH}_{2}\right), 25.8\left(\mathrm{CH}_{2}\right)$, $25.6\left(\mathrm{CH}_{2}\right), 24.93\left(\mathrm{CH}_{2}\right), 24.86\left(\mathrm{CH}_{2}\right)$;

EIMS m/z 295 (7), 271 (4), 243 (3), 189 (6), 170 (11), 157 (51), 155 (17), 138 (100), 127 (11), 121 (13), 110 (18), 97 (54), 87 (21), 84 (26), 74 (36), 69 (60), 59 (14), 55 (76), 43 (23), 41 (31);

$I(\mathrm{HP5}-\mathrm{MS})=2601$.

\section{Methyl (Z)-9-[(9-hydroxynonanoyl)oxy]non-6-enoate (Me-38)}

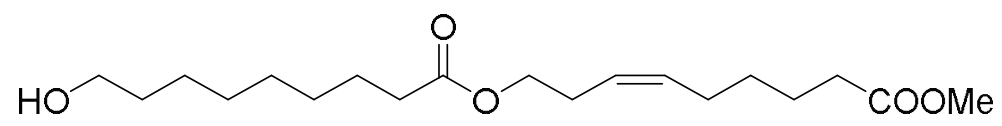

Methyl (Z)-9-\{[9-((tert-butyldimethylsilyl)oxy)nonanoyl]oxy $\}$ non-6-enoate $\quad(\mathbf{2 8}, \quad 17 \mathrm{mg}$, $0.036 \mathrm{mmol})$ yielded alcohol Me-38 (12 mg, $0.034 \mathrm{mmol}, 93 \%)$ after workup B.

$R_{\mathrm{f}}=0.15$ (pentane/diethyl ether $\left.1: 1\right)$;

IR (neat) $v_{\max } 3456$ (br), $2929(\mathrm{~m}), 2857$ (m), $1733(\mathrm{~s}), 1438$ (m), 1355 (m), 1168 (s), $1105(\mathrm{~m})$, $1053(\mathrm{~m}), 727(\mathrm{~m}) \mathrm{cm}^{-1}$;

${ }^{1} \mathrm{H}$ NMR $\left(\mathrm{CDCl}_{3}, 300 \mathrm{MHz}\right) \delta$ 5.53-5.44 $(1 \mathrm{H}, \mathrm{m},=\mathrm{CH}), 5.41-5.31(1 \mathrm{H}, \mathrm{m},=\mathrm{CH}), 4.06(2 \mathrm{H}, \mathrm{t}$, $\left.J=6.9 \mathrm{~Hz}, \mathrm{CH}_{2}\right), 3.67\left(3 \mathrm{H}, \mathrm{s}, \mathrm{CH}_{3}\right), 3.64\left(2 \mathrm{H}, \mathrm{t}, J=6.6 \mathrm{~Hz}, \mathrm{CH}_{2}\right), 2.41-2.33\left(2 \mathrm{H}, \mathrm{m}, \mathrm{CH}_{2}\right)$, $2.32\left(2 \mathrm{H}, \mathrm{t}, J=7.5 \mathrm{~Hz}, \mathrm{CH}_{2}\right), 2.29\left(2 \mathrm{H}, \mathrm{t}, J=7.6 \mathrm{~Hz}, \mathrm{CH}_{2}\right), 2.11-2.03\left(2 \mathrm{H}, \mathrm{m}, \mathrm{CH}_{2}\right), 1.70-1.51$ (7H, m, $\left.3 \mathrm{CH}_{2}, \mathrm{OH}\right), 1.44-1.25\left(10 \mathrm{H}, \mathrm{m}, 5 \mathrm{CH}_{2}\right)$; 
${ }^{13} \mathrm{C} \mathrm{NMR}\left(\mathrm{CDCl}_{3}, 75 \mathrm{MHz}\right) \delta 174.1(\mathrm{C}), 173.9(\mathrm{C}), 132.1(\mathrm{CH}), 124.9(\mathrm{CH}), 63.7\left(\mathrm{CH}_{2}\right), 63.0$ $\left(\mathrm{CH}_{2}\right), 51.5\left(\mathrm{CH}_{3}\right), 34.3\left(\mathrm{CH}_{2}\right), 33.9\left(\mathrm{CH}_{2}\right), 32.7\left(\mathrm{CH}_{2}\right), 29.2\left(2 \mathrm{CH}_{2}\right), 29.0\left(2 \mathrm{CH}_{2}\right), 26.91$ $\left(\mathrm{CH}_{2}\right), 26.86\left(\mathrm{CH}_{2}\right), 25.6\left(\mathrm{CH}_{2}\right), 24.9\left(\mathrm{CH}_{2}\right), 24.5\left(\mathrm{CH}_{2}\right)$;

EIMS m/z 293 (3), 168 (36), 157 (7), 136 (44), 121 (6), 108 (15), 94 (100), 79 (20), 69 (20), 67 (23), 55 (30), 41 (16);

$I(\mathrm{HP} 5-\mathrm{MS})=2581$.

\section{Methyl 9-\{[(Z)-9-hydroxynon-6-enoyl]oxy\}nonanoate (Me-36)}<smiles>COC(=O)CCCCCCCCOC(=O)CCCC/C=C/CCO</smiles>

Methyl 9-\{[(Z)-9-((tert-butyldimethylsilyl)oxy)non-6-enoyl]oxy\}nonanoate $0.022 \mathrm{mmol}$ ) yielded alcohol Me-36 (7 mg, $0.020 \mathrm{mmol}, 92 \%)$ after workup B.

(29, $10 \mathrm{mg}$, $R_{\mathrm{f}}=0.15$ (pentane/diethyl ether $\left.1: 1\right)$;

IR (neat) $v_{\max } 3450(\mathrm{br}), 3007(\mathrm{w}), 2930(\mathrm{~m}), 2857$ (m), 1733 (s), 1437 (m), 1356 (m), 1171 (s), $1104(\mathrm{~m}), 1048(\mathrm{~s}), 872(\mathrm{w}), 724(\mathrm{~m}), 584(\mathrm{w}) \mathrm{cm}^{-1}$;

${ }^{1} \mathrm{H} \mathrm{NMR}\left(\mathrm{CDCl}_{3}, 300 \mathrm{MHz}\right) \delta 5.59-5.50(1 \mathrm{H}, \mathrm{m},=\mathrm{CH}), 5.44-5.34(1 \mathrm{H}, \mathrm{m},=\mathrm{CH}), 4.05(2 \mathrm{H}, \mathrm{t} J$ $\left.=6.7 \mathrm{~Hz}, \mathrm{CH}_{2}\right), 3.67\left(3 \mathrm{H}, \mathrm{s}, \mathrm{CH}_{3}\right), 3.65\left(2 \mathrm{H}, \mathrm{t}, J=6.5 \mathrm{~Hz}, \mathrm{CH}_{2}\right), 2.37-2.29\left(2 \mathrm{H}, \mathrm{m}, \mathrm{CH}_{2}\right), 2.30$ $\left(4 \mathrm{H}, \mathrm{t}, J=7.5 \mathrm{~Hz}, 2 \mathrm{CH}_{2}\right), 2.13-2.05\left(2 \mathrm{H}, \mathrm{m}, \mathrm{CH}_{2}\right), 1.69-1.56\left(7 \mathrm{H}, \mathrm{m}, 3 \mathrm{CH}_{2}, \mathrm{OH}\right), 1.45-1.26$ $\left(10 \mathrm{H}, \mathrm{m}, 5 \mathrm{CH}_{2}\right)$;

${ }^{13} \mathrm{C} \mathrm{NMR}\left(\mathrm{CDCl}_{3}, 75 \mathrm{MHz}\right) \delta 174.3(\mathrm{C}), 173.8(\mathrm{C}), 132.6(\mathrm{CH}), 125.6(\mathrm{CH}), 64.4\left(\mathrm{CH}_{2}\right), 62.3$ $\left(\mathrm{CH}_{2}\right), 51.5\left(\mathrm{CH}_{3}\right), 34.2\left(\mathrm{CH}_{2}\right), 34.1\left(\mathrm{CH}_{2}\right), 30.8\left(\mathrm{CH}_{2}\right), 29.11\left(\mathrm{CH}_{2}\right), 29.09\left(\mathrm{CH}_{2}\right), 29.0\left(2 \mathrm{CH}_{2}\right)$, $28.6\left(\mathrm{CH}_{2}\right), 26.9\left(\mathrm{CH}_{2}\right), 25.8\left(\mathrm{CH}_{2}\right), 24.9\left(\mathrm{CH}_{2}\right), 24.6\left(\mathrm{CH}_{2}\right)$;

EIMS m/z 312 (7), 293 (6), 292 (7), 280 (7), 189 (8), 171 (8), 155 (31), 139 (43), 136 (66), 124 (100), 121 (18), 108 (22), 97 (47), 94 (61), 87 (16), 81 (36), 74 (26), 69 (58), 67 (39), 59 (20), 55 (95), 43 (30), 41 (42);

$I(\mathrm{HP} 5-\mathrm{MS})=2586$.

Methyl (Z)-9-\{[(Z)-9-hydroxynon-6-enoyl]oxy\}non-6-enoate (Me-40)<smiles>COC(=O)CCCC/C=C/CCOC(=O)CCCC/C=C/CCO</smiles>

Methyl (Z)-9-\{[(Z)-9-((tert-butyldimethylsilyl)oxy)non-6-enoyl]oxy $\}$ non-6-enoate (30, 19 mg, $0.041 \mathrm{mmol}$ ) yielded alcohol Me-40 (14 mg, $0.041 \mathrm{mmol}$, quant.) after workup B.

$R_{\mathrm{f}}=0.14$ (pentane/diethyl ether $\left.1: 1\right)$;

IR (neat) $v_{\max } 3458$ (br), $3010(\mathrm{w}), 2936(\mathrm{~m}), 2861(\mathrm{w}), 1732(\mathrm{~s}), 1438(\mathrm{~m}), 1353(\mathrm{~m}), 1171(\mathrm{~s})$, $1106(\mathrm{w}), 1050$ (s), 1013 (m), 870 (w), 725 (m), $586(\mathrm{w}) \mathrm{cm}^{-1}$; 
${ }^{1} \mathrm{H}$ NMR $\left(\mathrm{CDCl}_{3}, 300 \mathrm{MHz}\right) \delta 5.59-5.31(4 \mathrm{H}, \mathrm{m}, 4=\mathrm{CH}), 4.06\left(2 \mathrm{H}, \mathrm{t}, J=6.9 \mathrm{~Hz}, \mathrm{CH}_{2}\right), 3.67$ $\left(3 \mathrm{H}, \mathrm{s}, \mathrm{CH}_{3}\right), 3.64\left(2 \mathrm{H}, \mathrm{t}, J=6.5 \mathrm{~Hz}, \mathrm{CH}_{2}\right), 2.41-2.28\left(8 \mathrm{H}, \mathrm{m}, 4 \mathrm{CH}_{2}\right), 2.13-2.03(4 \mathrm{H}, \mathrm{m}, 2$ $\left.\mathrm{CH}_{2}\right), 1.69-1.59\left(5 \mathrm{H}, \mathrm{m}, 2 \mathrm{CH}_{2}, \mathrm{OH}\right), 1.45-1.33\left(4 \mathrm{H}, \mathrm{m}, 2 \mathrm{CH}_{2}\right)$;

${ }^{13} \mathrm{C} \mathrm{NMR}\left(\mathrm{CDCl}_{3}, 75 \mathrm{MHz}\right) \delta 174.1(\mathrm{C}), 173.7(\mathrm{C}), 132.6(\mathrm{CH}), 132.1(\mathrm{CH}), 125.6(\mathrm{CH}), 124.9$ $(\mathrm{CH}), 63.7\left(\mathrm{CH}_{2}\right), 62.3\left(\mathrm{CH}_{2}\right), 51.5\left(\mathrm{CH}_{3}\right), 34.1\left(\mathrm{CH}_{2}\right), 33.9\left(\mathrm{CH}_{2}\right), 30.8\left(\mathrm{CH}_{2}\right), 29.1\left(\mathrm{CH}_{2}\right)$, $29.0\left(\mathrm{CH}_{2}\right), 26.93\left(\mathrm{CH}_{2}\right), 26.90\left(\mathrm{CH}_{2}\right), 26.85\left(\mathrm{CH}_{2}\right), 24.5\left(2 \mathrm{CH}_{2}\right)$;

EIMS m/z 310 (2), 168 (37), 155 (20), 137 (54), 124 (16), 119 (17), 109 (24), 94 (100), 81 (25), 79 (32), 67 (49), 59 (11), 55 (40), 43 (12), 41 (23);

$I(\mathrm{HP} 5-\mathrm{MS})=2569$.

\section{Stability of 1-Methylene-1 $H$-pyrrolizine (13)}

Fractions (concentration $\leq 0.28 \mathrm{mg} / \mathrm{mL}$ ) containing freshly prepared 1-methylene-1 $\mathrm{H}$ pyrrolizine (13) were obtained from chromatography on alumina with pentane. A subfraction was concentrated in vacuo to a final concentration of $1.9 \mathrm{mg} / \mathrm{mL}$. These solutions were stored at room temperature or $-25^{\circ} \mathrm{C}$ in clear vials and the content of $\mathbf{1 3}$ in the samples was monitored by GC. The concentrated solution had a short half-life period of $2.75 \mathrm{~h}$, while the value for the dilute solution was $22 \mathrm{~h}$. Storing samples in the dark did not alter the results. In contrast, the sample stored at $-25^{\circ} \mathrm{C}$ showed only minimal degradation after two days (Figure S6). The actual concentrations might be lower, because degradation products might already be present at the beginning of the test period, although NMR analyses showed prominently compound $\mathbf{1 3}$.

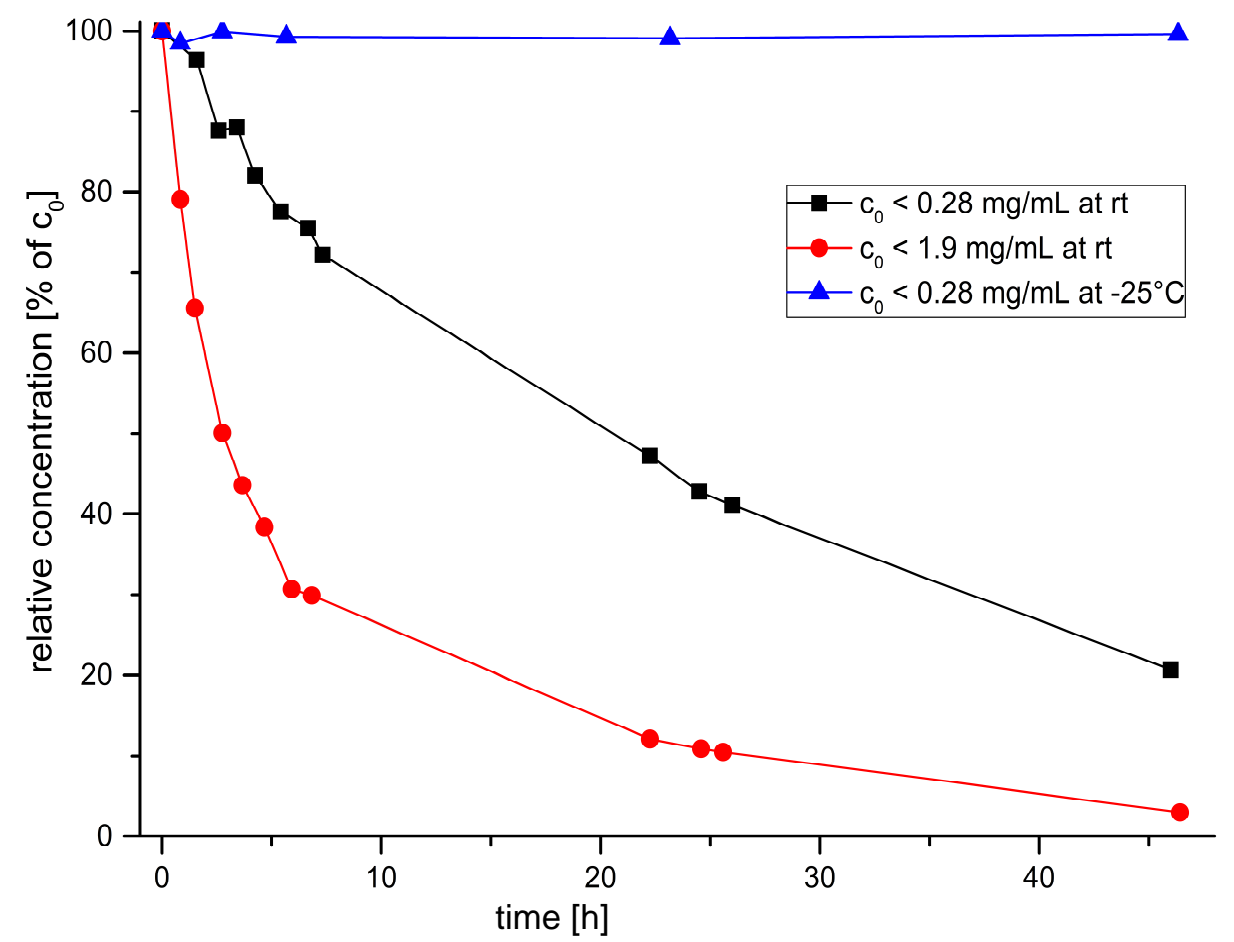

Figure S6: Stability of 1-methylene-1H-pyrrolizine (13, solution in pentane), determined by GC. 


\section{NMR and IR Spectra}

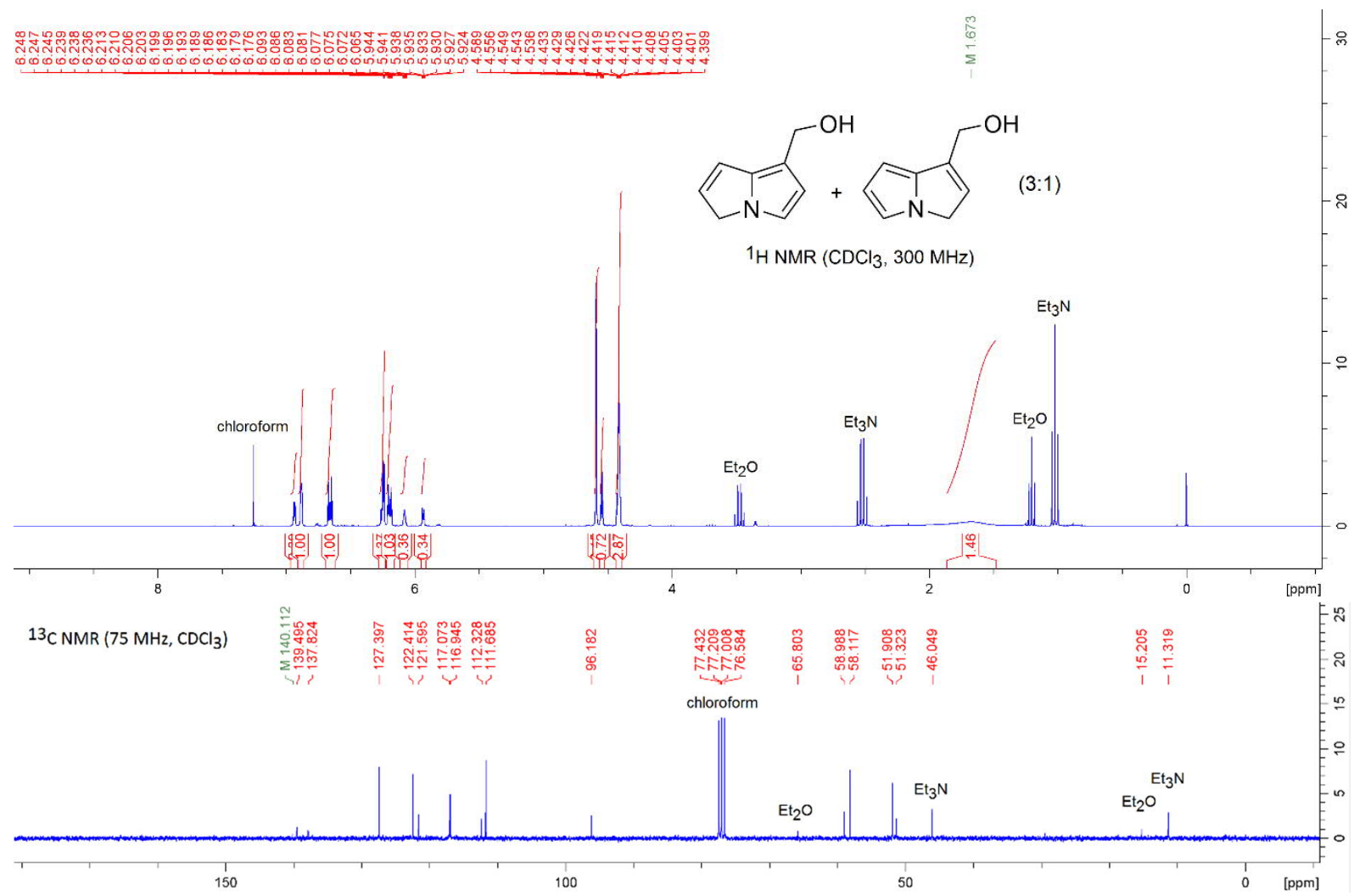

Figure S7: NMR spectra of a 3:1 mixture of (3H-pyrrolizin-7-yl)methanol (12) and (1H-pyrrolizin-1yl)methanol (14).

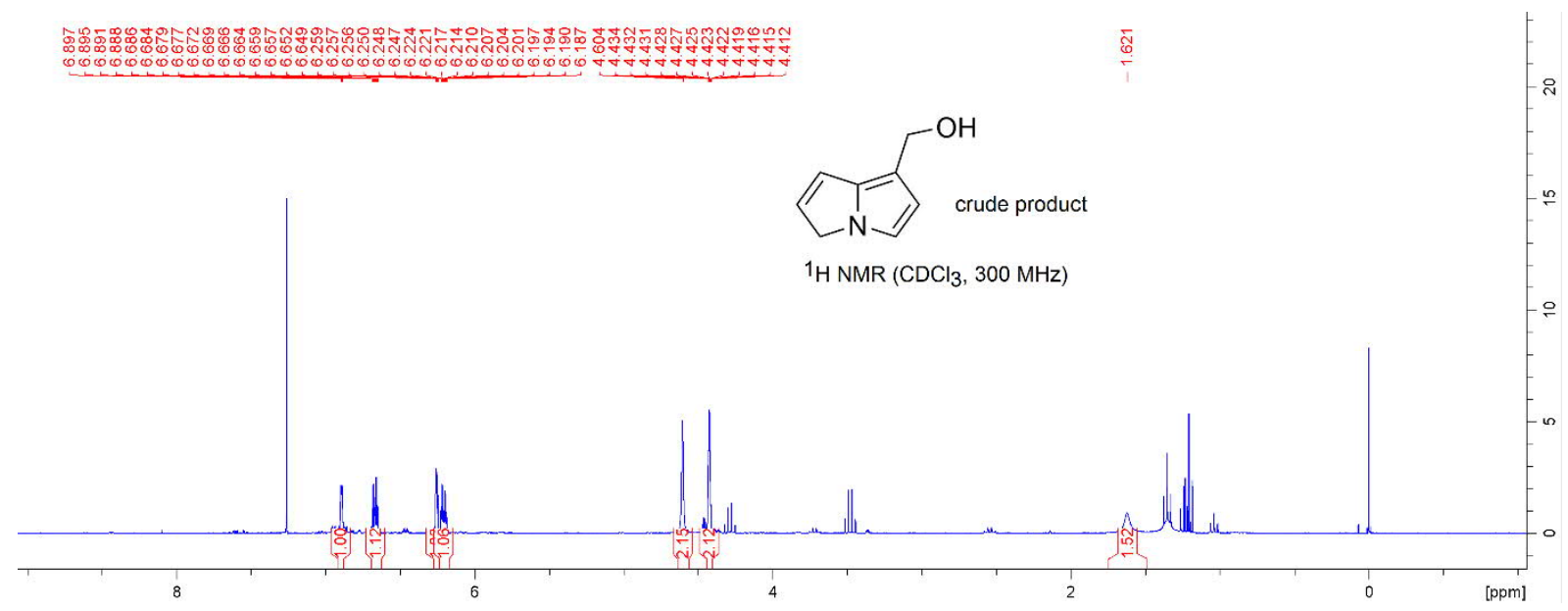

Figure S8: ${ }^{1} \mathrm{H}$ NMR spectrum of crude (3H-pyrrolizin-7-yl)methanol (12). 


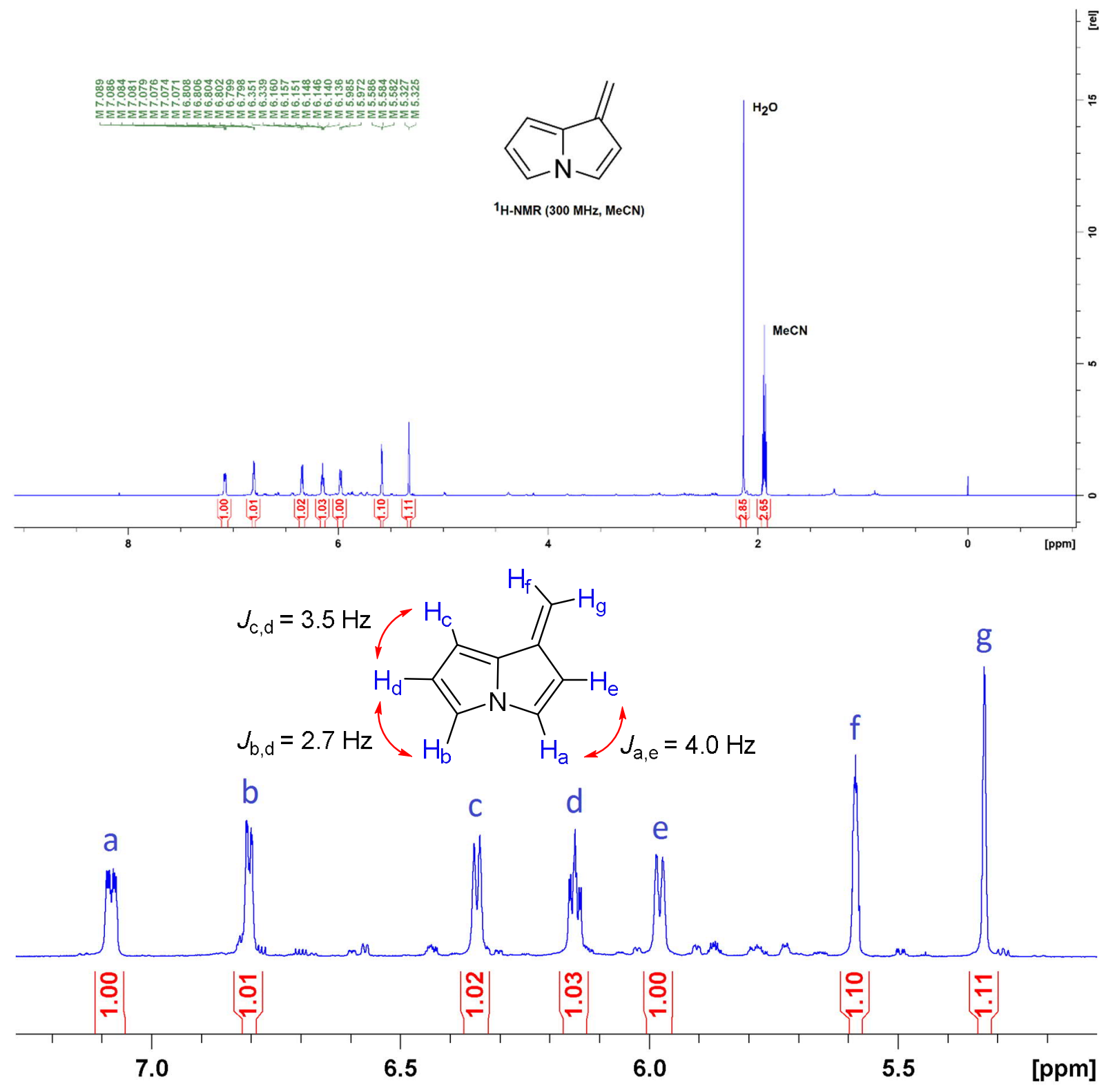

Figure S9: ${ }^{1} \mathrm{H}$ NMR spectrum of 1-methylene-1 $H$-pyrrolizine (13). 
Table S1. NMR data (300 MHz, $\mathrm{CD}_{3} \mathrm{CN}$ ) of 1-methylene-1 $H$-pyrrolizine (13)

\begin{tabular}{cc}
\hline position & $\delta_{\mathrm{H}}(\mathrm{J}$ in Hz) \\
\hline 2 & $5.98, \mathrm{brd}(4.0)$ \\
3 & $7.08, \mathrm{dm}(4.0)$ \\
5 & $6.80, \mathrm{dm}(2.7)$ \\
6 & $6.15, \mathrm{ddd}(3.5,2.7,1.1)$ \\
7 & $6.35, \mathrm{br} \mathrm{d}(3.5)$ \\
methylene & $5.59, \mathrm{br} \mathrm{s}, 5.33, \mathrm{br} \mathrm{s}$ \\
\hline
\end{tabular}

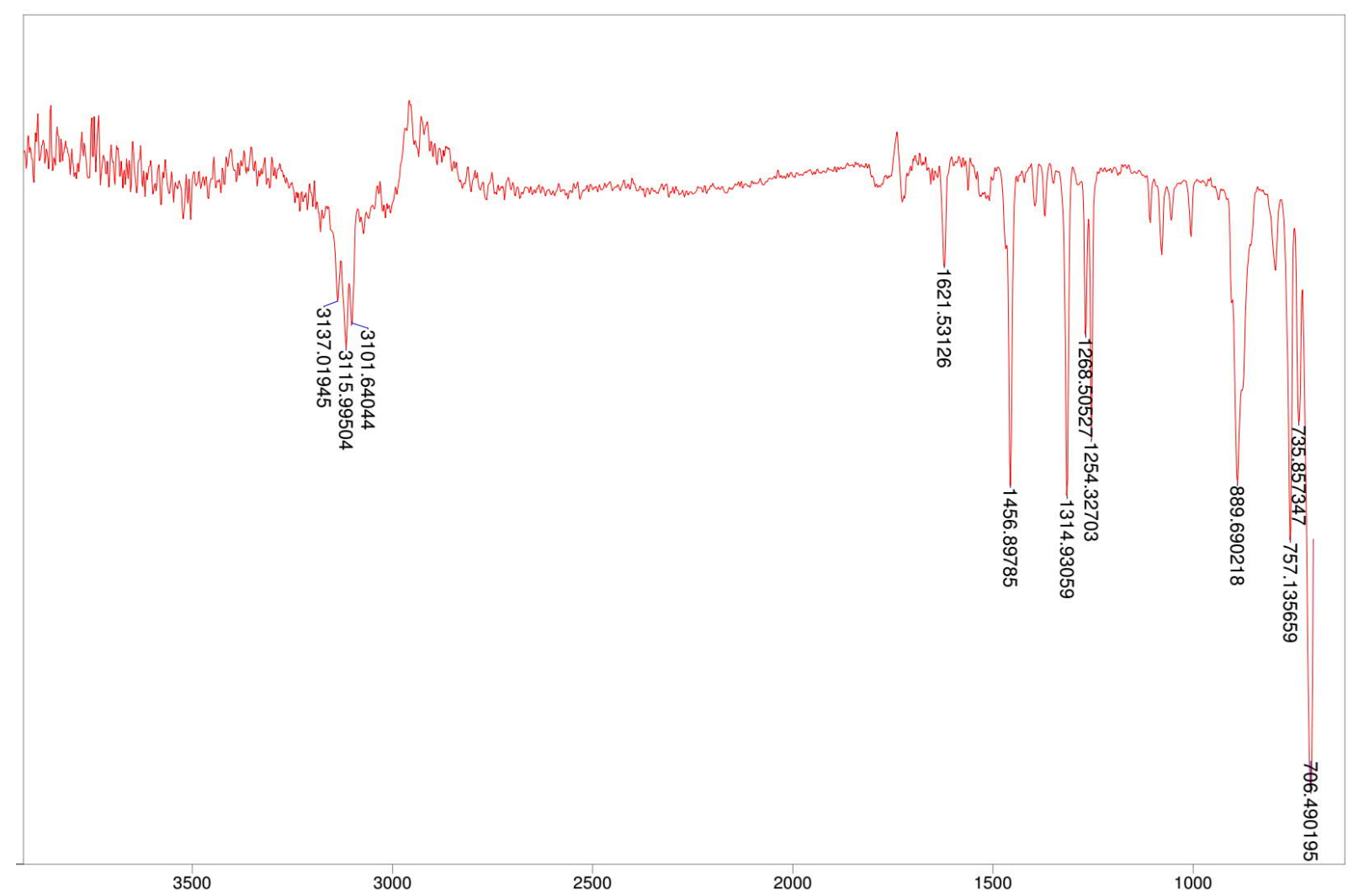

Figure S10: IR spectrum of 1-methylene-1 $H$-pyrrolizine (13). 


\section{References}

Aguilar AL, Escribano J, Wentworth P, Butters TD (2014) Synthetic 1-Deoxynojirimycin $N$ Substituted Peptides Offer Prolonged Disruption to $N$-Linked Glycan Processing. ChemMedChem 9:2809-2813

Corey EJ, Venkateswarlu A (1972) Protection of Hydroxyl Groups as tert.-Butyldimethylsilyl Derivates. J Am Chem Soc 94:6190-6191

Cossy J, Pete JP (1986) A one step synthesis of $\omega$-hydroxyacetylenic carboxylic acids. Tetrahedron Lett 27:573-574

Dasmahapatra KK, Lamas G, Simpson F, Mallet J (2010) The anatomy of a 'suture zone' in Amazonian butterflies: A coalescent-based test for vicariant geographic divergence and speciation. Mol Ecol 19:4283-4301

De-Silva DL, Vásquez AS, Mallet J (2011) Selection for enemy-free space - Eggs placed away from the host plant increase survival of a neotropical ithomiine butterfly. Ecol Entomol 36:667-672

Hinman AW, Richards SJ (2018) Fluoroalkyl, fluoroalkoxy, phenoxy, heteroaryloxy, alkoxy, and amine 1,4-benzoquinone derivatives for treatment of oxidative stress disorders: United States patent US 20180370892

Johnson F, Paul KG, Favara D (1982) An efficient synthesis of methyl dl- cis-jasmonate. J Org Chem 47:4254-4255

Mori K, Kisida H (1986) Synthesis of both the enantiomers of the heterocyclic pheromones isolated from the male swift moth Hepialus hecta L. Tetrahedron 42:5281-5290

Page PCB, Vahedi H, Batchelor KJ, Hindley SJ, Edgar M, Beswick P (2003) Synthesis of an isomer of the oxaspirobicyclic tetronic acid unit of the CCK-B receptor antagonist tetronothiodin. Synlett:1022-1024

Pappo R, Allen jr. DS, Lemieux RU, Johnson WS (1956) Osmium Tetroxide-Catalyzed Periodate Oxidation of Olefinic Bonds. J Org Chem 21:478-479

Rao CG (1980) A new rapid esterification procedure utilizing exceptionally mild reaction conditions. Org. Prep. Proc. Int. 12:225-228

Wube AA, Hüfner A, Thomaschitz C, Blunder M, Kollroser M, Bauer R, Bucar F (2011) Design, synthesis and antimycobacterial activities of 1-methyl-2-alkenyl-4(1 $H)$-quinolones. Bioorg Med Chem 19:567-579

Yoon NM, Pak CS, Brown HC, Krishnamurthy S, Stocky TP (1973) Rapid reaction of carboxylic acids with borane-tetrahydrofuran. J Org Chem 38:2786-2792 